\title{
WPS3621
}

\section{Assessing the Impact of the Investment Climate on Productivity Using Firm-Level Data: Methodology and the Cases of Guatemala, Honduras, and Nicaragua ${ }^{1}$}

\author{
Alvaro Escribano ${ }^{2}$ \\ Universidad Carlos III, Madrid and Georgetown University, Washington, D.C. \\ and \\ J. Luis Guasch \\ World Bank and University of California, San Diego
}

World Bank Policy Research Working Paper 3621, June 2005

The Policy Research Working Paper Series disseminates the findings of work in progress to encourage the exchange of ideas about development issues. An objective of the series is to get the findings out quickly, even if the presentations are less than fully polished. The papers carry the names of the authors and should be cited accordingly. The findings, interpretations, and conclusions expressed in this paper are entirely those of the authors. They do not necessarily represent the view of the World Bank, its Executive Directors, or the countries they represent. Policy Research Working Papers are available online at http://econ.worldbank.org.

\footnotetext{
${ }^{1}$ We are indebted to Heisnam Singh for his excellent research assistance. The empirical section, which illustrates the implementation of this econometric methodology, is an extension of initial work with Ana M. Fernandes and Heisnam Singh. We have benefited from the suggestions and questions from Juan Miguel Crivelli, Pablo Fajnzylber, Luke Haggarty, Danny Leipziger, Marialisa Motta, Isabel Sánchez and Stefka Slavova, and from participants at a World Bank seminar. Escribano gratefully acknowledges financial support from the Foundation BBVA (Spain).

${ }^{2}$ Telefonica-UCIIIM Chair on Economics of Telecommunications.
} 


\begin{abstract}
Developing countries are increasingly concerned about improving country competitiveness and productivity, as they face the increasing pressures of globalization and attempt to improve economic growth and reduce poverty. Among such countries, Investment Climate Assessments (ICA) have become a standard instrument for identifying key obstacles to country competitiveness and imputing their impact on productivity, in order to prioritize policy reforms for enhancing competitiveness. Given the survey objectives and the nature and limitations of the data collected, this report discusses the advantages and disadvantages of using different productivity measures based on data at the firm level. The main objective is to develop a methodology to appropriately estimate, in a robust manner, the productivity impact of the investment climate variables. To illustrate the use of this methodology, the report applies it to the data collected for ICAs in three countries: Guatemala, Honduras and Nicaragua. Observations in logarithms (logs) of the variables, and not in rates of growth, are pooled from all three countries. The econometric analysis is done with variables in logs to reduce the impact of measurement errors and allow inclusion of as many observations as possible since the "panel" data set is very unbalanced. Endogeneity of the production function inputs and of the investment climate variables is addressed by using a variant of the control function approach, based on individual firm information, and by aggregating investment climate variables by industry and region.
\end{abstract}

It is shown that it is possible to get robust results for 10 different productivity measures, if one follows a consistent econometric methodology of specification and estimation. For policy analysis, the report strongly recommends using those results of investment climate variables on productivity that are robust for most of the productivity measures. Efficiency aspects of firms in each country are also analyzed. Finally, the results are decomposed to obtain country-specific impacts and establish corresponding priorities for policy reform. The actual estimates for the three countries show the level of significance of the impact of investment climate variables on productivity. Variables in several categories, red tape and infrastructure in particular, appear to account for over 30 percent of productivity. The policy implications are clear: investment climate matters enormously and the relative impact of the various investment climate variables indicates where reform efforts should be directed. Given the robustness of the results, it is argued that the econometric methodology of productivity analysis developed here ought to be used as a benchmark to assess productivity effects for other ICAs or surveys with firm-level data of similar characteristics. 


\section{Assessing the Impact of the Investment Climate on Productivity Using Firm-Level Data: Methodology and the Cases of Guatemala, Honduras, and Nicaragua}

\section{Contents}

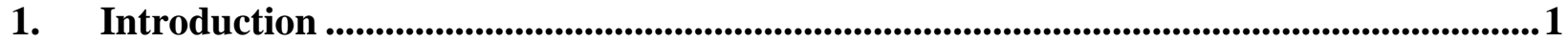

2. Productivity (P) Measures and Total Factor Productivity (TFP) .....................................5

3. Productivity Measures Based on the Rates of Growth. ........................................................7

4. Alternative Productivity Measures Based on Variables in Levels ....................................15

5. Proposed Econometric Methodology to Estimate the Productivity Impact of Investment Climate (IC) Variables in Guatemala, Honduras and Nicaragua 23

6. Step-by-Step Implementation of this Productivity Methodology ......................................34

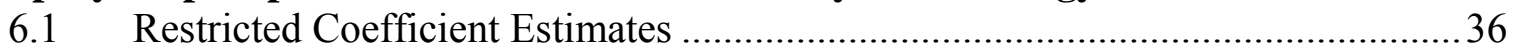

6.2 Unrestricted Production Function Coefficients Estimated by Industry ...................39

6.3 Further Productivity Analysis of IC Determinants by Age and by Size of the Firms.

7. Production Allocation Efficiency by Country, by Size of the Firms and by Industry.

8. Empirical Results on Investment Climate (IC) Determinants of Productivity in Guatemala, Honduras and Nicaragua.............................................................................45

8.1 Productivity Elasticities or Semi-Elasticities of Each IC Variable.....................46

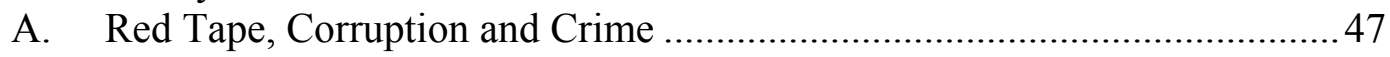

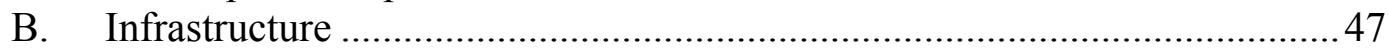

C. Quality, Innovation and Labor Skills ........................................................48

D. Finance and Corporate Governance ..........................................................49

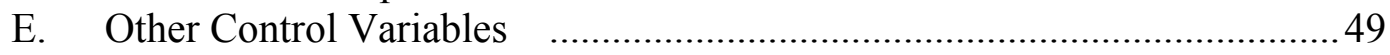

8.2 Country Specific Productivity Impact of Each IC Variable ...................................51

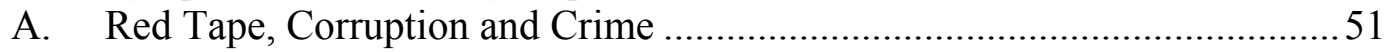

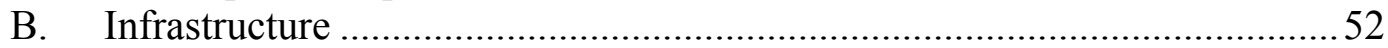

C. Quality, Innovation and Labor Skills .........................................................53

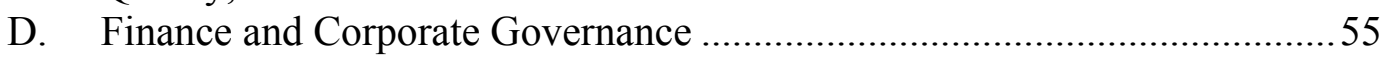

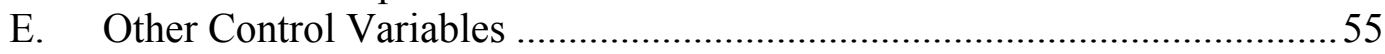

8.3 Olley and Pakes (1996) Productivity Decomposition for Each Country ...............62

9. Conclusion

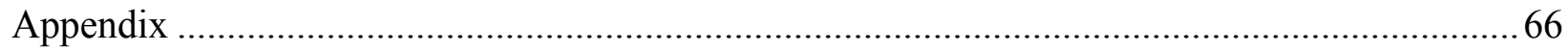

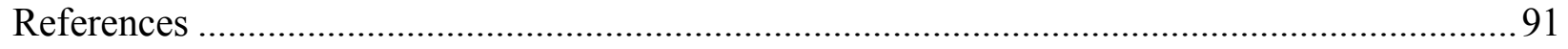




\section{List of Figures and Tables}

Figure 1: Productivity Elasticities or Semi-elasticities with Respect to IC Variables 50

Figure 2:

Guatemala: Productivity Impact (gains and losses) of Investment Climate

Variables (in \%)

Figure 3: $\quad$ Honduras: Productivity Impact (gains and losses) of Investment Climate

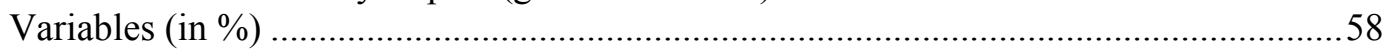

Figure 4: $\quad$ Nicaragua: Productivity Impact (gains and losses) of Investment Climate

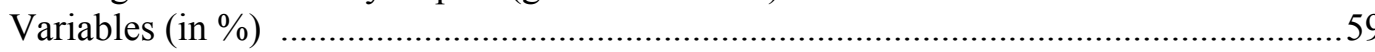

Figure 5: $\quad$ Productivity Impact in Guatemala, Honduras and Nicaragua due to

Investment Climate Variables (in \%) (Cumulative Contribution) ...................................6 60

Figure 6: $\quad$ Productivity Impact in Guatemala, Honduras and Nicaragua due to

Investment Climate Variables (in \%) (Cumulative Absolute Contribution) ......................61

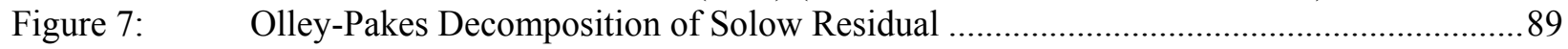

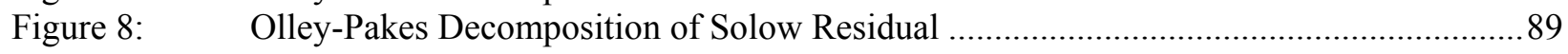

Figure 9: $\quad$ Olley-Pakes Decomposition of Industry Solow Residual

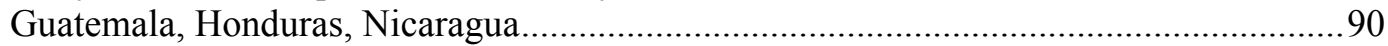

Table A.1: General Information at Plant Level and Production Function Variables .........................66

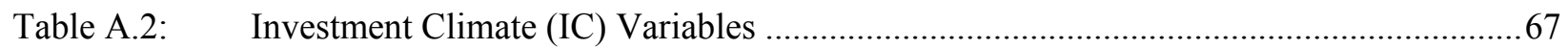

Table A.3: $\quad$ Other IC and Plant Characteristics (C) Variables ........................................................6

Table A.4: $\quad$ Investment Climate - Perception (PE) Variables ............................................................6

Table B.1: $\quad$ Number of Firms that Enter into the IC Regressions by Industry and by

Country.....

Table B.2: $\quad$ Number of Firms that Enter into the IC Regressions by Industry and by

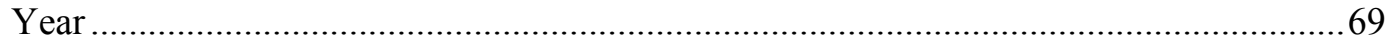

Table B.3: $\quad$ List of Significant ICA Variables and their Measurement Units .....................................70

Table C.1: $\quad$ Correlation between Solow Residuals in Levels and Estimated

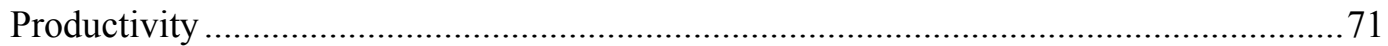

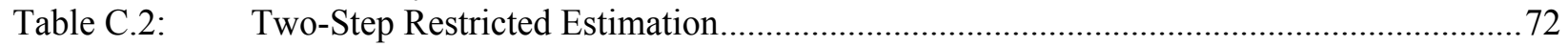

Table C.3.1: $\quad$ Single Step Restricted Estimation: Cobb Douglas Specification ...................................73

Table C.3.2: $\quad$ Single-Step Restricted Estimation: Translog Specification ............................................74

Table C.3.3: $\quad$ Production Function Parameters from the Restricted Estimation .................................. 75

Table C.4.1: $\quad$ Two-Step Unrestricted by Industry Estimation.............................................................76

Table C.4.2: Two-Step Unrestricted by Industry Estimation with Perception Variables ..................... 77

Table C.5.1: $\quad$ Single-Step Unrestricted by Industry Estimation: Cobb Douglas

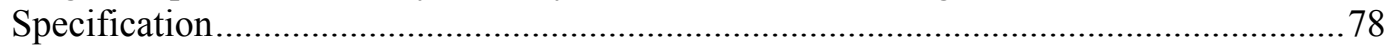

Table C.5.2: $\quad$ Single-Step Unrestricted by Industry Estimation: Translog Specification......................79

Table C.5.3: Production Function Parameters from the Unrestricted Estimation by Industry: Cobb Douglas Specification

Table C.5.4: $\quad$ Production Function Parameters from the Unrestricted by Industry

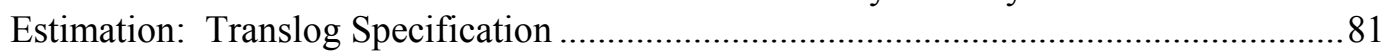

Table C.6.1: $\quad$ Two Step Unrestricted by Industry Estimation for Young and Old Firms.......................82

Table C.6.2: $\quad$ Two Step Unrestricted by Industry Estimation for Small and Large Firms......................83

Table C.7.1: Covariance Terms by Country of the Olley-Pakes Decomposition from 84

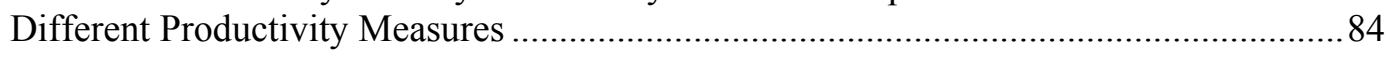

Table C.7.2: $\quad$ Covariance Terms by Country and Plant Size of the Olley-Pakes

Decomposition from Different Productivity Measures .......................................................8 84

Table D: $\quad$ Elasticities or Semi-elasticities and Percentage R-square Productivity

Contribution of Each Explanatory Variable, after Controlling for the Other

IC and Plant Control Variables .

Table E.1: Guatemala: \% Average (log) Productivity Gains and Losses in Guatemala 


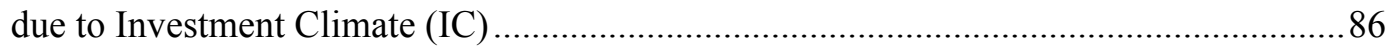

Table E.2: $\quad$ Honduras: \% Average (log) Productivity Gains and Losses in Honduras

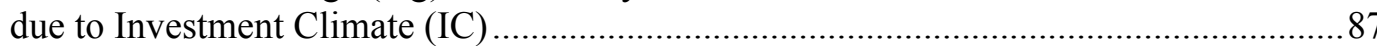

Table E.3: $\quad$ Nicaragua: \% Average (log) Productivity Gains and Losses in Nicaragua due to Investment Climate (IC) 


\section{Introduction}

As developing countries face the pressures and impacts of globalization, they are seeking ways to stimulate growth and employment within this context of increased openness. With most of these countries having secured a reasonable level of macroeconomic stability, they are now focusing on issues of competitiveness and productivity through microeconomic reform programs. From South East Asia to Latin America, countries are reformulating their strategies and making increased competitiveness a key priority of government programs.

A significant component of country competitiveness is having a good investment climate or business environment. The investment climate, as defined in the WDR (2005), is "the set of location-specific factors shaping the opportunities and incentives for firms to invest productively, create jobs and expand." It is now well accepted and documented, conceptually and empirically, that the scope and nature of regulations on economic activity and factor markets - the so-called investment climate and business environment - can significantly and adversely impact productivity, growth and economic activity (see Bosworth and Collins, 2003; Dollar et al., 2004; Rodrik and Subramanian, 2004; Loayza, Oviedo and Serven, 2004; McMillan, 1998 and 2004; OECD, 2001; Wilkinson, 2001; Alexander et al., 2004; Djankov et al., 2002; Haltiwanger, 2002; He et al., 2003; World Bank, 2003; World Bank, 2004 a,b); and Hall and Jones (1999). Prescott (1998) argues that to understand large international income differences, it is necessary to explain differences in productivity (TFP). His main candidate to explain those gaps is the resistance to the adoption of new technologies and to the efficient use of current operating technologies, which in turn are conditioned by the institutional and policy arrangements a society employs (investment climate variables). Recently, Cole et al. (2004) also have argued that Latin America has not replicated Western economic success due to the productivity (TFP) gap. They point to competitive barriers (investment climate variables) as the promising channels for understanding the low productivity observed in Latin American countries. 
Government policies and behavior exert a strong influence on the investment climate through their impact on costs, risks and barriers to competition. Key factors affecting the investment climate through their impact on costs are: corruption, taxes, the regulatory burden and extent of red tape in general, factor markets (labor and capital), the quality of infrastructure, technological and innovation support, and the availability and cost of finance.

For example, Kasper (2002) shows that poorly understood "state paternalism" has usually created unjustified barriers to entrepreneurial activity, resulting in poor growth and a stifling environment. Kerr (2002) shows that a quagmire of regulation, which is all too common, is a massive deterrent to investment and economic growth. As a case in point, McMillan (1988) argues that obtrusive government regulation before 1984 was the key issue in New Zealand's slide in the world per-capita income rankings. Hernando de Soto (2002) describes one key adverse effect of significant business regulation and weak property rights: with costly firm regulations, fewer firms choose to register and more become informal. Also, if there are high transaction costs involved in registering property, assets are less likely to be officially recorded, and therefore cannot be used as collateral to obtain loans, thereby becoming "dead" capital.

Likewise, poor infrastructure and limited transport and trade services increase logistics costs, rendering otherwise competitive products uncompetitive, as well as limiting rural production and people's access to markets, which adversely affects poverty and economic activity (Guasch 2004).

The pursuit of greater competitiveness and a better investment climate is leading countries often assisted by multilaterals such as the World Bank - to undertake their own studies to identify the principal bottlenecks in terms of competitiveness and the investment climate, and evaluate the impact these have, to set priorities for intervention and reform. The most common instrument used has been firm-level surveys, known as Investment Climate 


\section{Econometric Methodologies for Investment Climate Assessments on Productivity}

Assessments (ICAs), from which both subjective evaluations of obstacles and objective harddata numbers with direct links to costs and productivity are elicited and imputed. Such surveys collect data at the firm level on the following themes: infrastructure, bureaucracy and corruption, technology and quality, human capital, corporate governance, crime and security, and financial services.

While the Investment Climate Assessments are quite useful in identifying major issues and bottlenecks as perceived by firms, the data collected are also meant to provide an assessment of the impact or contribution of the investment climate (IC) variables on productivity. In turn, that quantified impact is used in the advocacy for, and design of, investment-climate reform. Yet providing reliable and robust estimates of productivity estimates of the IC variables from the surveys is not a straightforward task. First, the surveys do not provide panel-type data. Second, the production function is not observed; and third, there is an identification issue separating Total Factor Productivity (TFP) from the production function. When any of the production function inputs is influenced by common causes affecting productivity, like IC variables or other plant characteristics, there is a simultaneous equation problem. In general, one should expect the productivity to be correlated with the production function inputs (technological progress is not Hicks neutral) and, therefore, inputs should be treated as endogenous regressors when estimating production functions. This demands special care in the econometric specification for estimating those productivity effects and in the choice of the most appropriate way of measuring productivity.

There is an extensive literature discussing the advantages and disadvantages of using different statistical estimation techniques and/or growth accounting (index number) techniques to estimate productivity or TFP. For overviews of different productivity concepts and aggregation alternatives see, for example, Solow (1957), Hall (1990), Foster, Haltiwanger and Krizan (1998), Batelsman and Doms (2000), Hulten (2001), Diewert and Nakamura (2002), Jorgenson (2003), Jorgenson, Gollop and Fraumeni (1987), Olley and Pakes (1996) and Barro and Sala-i-Martin (2004). In this paper we discuss the applicability of some of these 
techniques to the problem at hand and present adaptations and adjustments that provide a best fit for the described objective: estimating the productivity impact of IC variables collected through a firm-level survey (international longitudinal micro-level data sets).

The development of an appropriate and consistent econometric methodology to be used as a benchmark for evaluating the impact of IC variables on productivity at the firm level is the main objective of this paper. To illustrate its applicability and usefulness, the methodology is used to assess the productivity impact in three different countries, Guatemala, Honduras and Nicaragua, with the IC firm-level survey data collected for 2001 and 2002.

Using a common methodology when analyzing similar issues is essential for benchmarking and comparison of empirical results. Different research groups addressing a common issue with the same class of models should reach similar conclusions if they share the same data set, use the same variables and follow consistent econometric methodologies. However, any model or any econometric methodology should be complemented by alternative econometric approaches, to identify the limitations and the advantages or disadvantages of each approach. Having alternative consistent econometric methodologies and alternative well-specified models should be useful for isolating robust impacts of investment climate variables. Those empirical results that are robust to different approaches should help in the formulation of clear policy recommendations.

This paper, which is an updated and extended version of Escribano and Guasch (2004), is structured as follows. Section 2 introduces the concepts of productivity and discusses general productivity measures based on levels versus differences. Section 3 discusses the conditions that are behind the measures of productivity growth and the related estimation problems. In section 4 we conduct a similar analysis for the level (or logarithm) of productivity. The advantages and disadvantages of each procedure are discussed. We conclude that, given the characteristics of the data set, it is better to use the level of productivity rather than the rate of growth, as in Hall and Jones $(1997,1998)$. In section 5, we introduce a consistent 


\section{Econometric Methodologies for Investment Climate Assessments on Productivity}

econometric methodology for the selection of IC and firm explanatory variables for different productivity measures. We propose to complement the regression approach with the efficiency analysis from Olley and Pakes' (1996) decomposition of productivity. The step-bystep explanation of this methodology is presented in section 6 , where the consistent econometric strategy is applied to study the investment climate determinants of productivity in Guatemala, Honduras and Nicaragua. We also evaluate the differences in productivity impacts between large and small firms as well as between old and young firms. Section 7 evaluates the efficiency of the firms by country and by industry in each of the three countries, using the Olley and Pakes (1996) productivity decomposition. It also introduces a methodology to evaluate the specific contribution of the IC variables to average productivity, once we have estimated common elasticities by pooling the data from the three countries. Section 8 explains in intuitive terms the economic interpretation of the large amount of information obtained about individual elasticities or semi-elasticities (of the inputs and of the IC variables on productivity) and includes a summary of the main empirical results on the IC determinants of productivity in Guatemala, Honduras and Nicaragua. Finally, section 9 presents a summary of the econometric methodology and of the main conclusions. Most of the figures and tables with the definitions of the variables used and with the panel data estimation results, are included in the appendix.

Readers interested only in the empirical results should consider sections 7, 8, 9, and the appendix. Those interested in the implementation of this productivity methodology should read sections 5 to 7 . Finally, readers interested in knowing the underlying conditions behind each productivity (P) measure and behind the concepts of total factor productivity (TFP) and Solow's residual (SR) should turn to sections 2, 3 and 4.

\section{Productivity (P) Measures and Total Factor Productivity (TFP)}

The econometric methodologies discussed in this paper are applied to study the productivity determinants of variables collected at the firm level. In particular, we consider the impact of 


\section{Econometric Methodologies for Investment Climate Assessments on Productivity}

investment climate (IC) variables and other firm control variables (C) on several productivity measures. The IC variables belong to five broad categories: infrastructure, bureaucracy/corruption, crime, finance and other plant characteristics. (See Table A2 and A3 of the appendix).

But before we proceed, it is convenient to clarify what we mean by productivity. Productivity (P) refers to the effects of any variable different from the inputs --labor (L), intermediate materials (M) and capital services (K)-- affecting the production (sales) process.

To be more specific, consider that the production function $\mathrm{Q}=\mathrm{F}(\mathrm{L}, \mathrm{M}, \mathrm{K})$ and the productivity $\left(\mathrm{P}_{\mathrm{it}}\right)$ equation of the firm (i) at period $(\mathrm{t})$ are given by:

$$
\begin{aligned}
Y_{i t} & =F\left(L_{i t}, M_{i t}, K_{i t}\right) P_{i t} \\
P_{i t} & =G\left(\mathrm{IC}_{\mathrm{it}}, \mathrm{C}_{\mathrm{it}}\right) \exp \left(\mathrm{u}_{\mathrm{it}}\right)
\end{aligned}
$$

where $\mathrm{u}_{\mathrm{it}}$ is a random error term with properties that will be specified later on. The individual firms are indicated by the sub-index $\mathrm{i}=1,2, \ldots, \mathrm{N}$, where $\mathrm{N}$ is the total number of firms in the sample (we are pooling the observations from the three countries) and by the sub-index time $t$ $=1,2, \ldots, \mathrm{T}$, where $\mathrm{T}$ is the total number of years in the sample. In our data base, $\mathrm{N}$ is large and $\mathrm{T}$ is small.

When any of the input variables (L, M and $\mathrm{K}$ ) is influenced by common causes affecting productivity, like IC variables or other firm characteristic variables (C), we have a simultaneous equation problem. (See Marschak and Andews 1944; Griliches and Mairesse 1995). In general, we should expect productivity to be correlated with the inputs L, M and K (technological progress not Hicks neutral), and therefore the inputs must be treated as endogenous regressors when estimating production functions. A specific solution to this 


\section{Econometric Methodologies for Investment Climate Assessments on Productivity}

endogeneity problem of the inputs $\mathrm{L}, \mathrm{M}$ and $\mathrm{K}$ in (1a) will be presented in section 5 when estimation issues of production functions are discussed. ${ }^{3}$

Taking logarithms in (1a) and (1b),

$$
\begin{gathered}
\log Y_{i t}=\log Q_{i t}+\log P_{i t} \\
\log P_{i t}=\log G\left(\mathrm{IC}_{\mathrm{it}}, \mathrm{C}_{\mathrm{it}}\right)+\mathrm{u}_{\mathrm{it}}
\end{gathered}
$$

where $\log \mathrm{P}$ is the "residual" from equation (2a) and $\log \mathrm{Q}=\log \mathrm{F}(\mathrm{L}, \mathrm{M}, \mathrm{K})$. That is, the $\log$ of productivity $(\mathrm{P})$ is the difference between the logarithm of output (Log Y) and the logarithm of aggregate input ( $\log Q)$ formed by L, M and K. Differentiating (2a) and (2b) we get similar expressions for the rates of growth:

$$
\begin{aligned}
& d \log Y_{i t}=d \log Q_{i t}+d \log P_{i t} \\
& d \log P_{i t}=d \log G\left(\mathrm{IC}_{\mathrm{it}}, \mathrm{C}_{\mathrm{it}}\right)+d \mathrm{du}_{\mathrm{it}} .
\end{aligned}
$$

From equations (3a) and (3b) it is clear that we would like to be able to assign to dlog $\mathrm{P}_{\text {it }}$ all those changes different than $L_{i t}, M_{i t}$ and $K_{i t}$, that shift the production function of firm $i$ in period $\mathrm{t}$, while associating the movements along the production function with changes in the aggregate input ${ }^{4}, \mathrm{dlog}_{\mathrm{it}}$. However, to do that, technical progress must be Hicks neutral.

\footnotetext{
${ }^{3}$ Blundell and Powell (2000) discuss a solution to this endogenous regressors problem based on a generalized method of moments (GMM) approach, applied to persistent panel data. Olley and Pakes (1996), Levinsohn and Petrin (2003) and Akerberg and Caves 2003) suggest structural approaches to estimate production functions under the condition that there is a single source of simultaneity. Unfortunately, those procedures suffer similar simultaneous equation bias, as we will discuss in section 5.2. In this paper, we approach the simultaneous equation problem by estimating all the parameters in one step. Furthermore, to control for the endogeneity of the IC variables we use industry regional averages by country, complemented with an alternative structural approach inspired by the control function approach. (See Blundell and Powell 2003). This procedure allows for several sources of simultaneity associated with IC variables at the firm level, which are usually unobserved (fixed effects).

${ }^{4}$ Consider the extended production function $\mathrm{Y}_{\mathrm{it}}=\mathrm{F}\left(\mathrm{L}_{\mathrm{it}}, \mathrm{M}_{\mathrm{it}}, \mathrm{K}_{\mathrm{it}}, \mathrm{P}_{\mathrm{it}}\right)$, where $\mathrm{P}_{\mathrm{it}}$ is an aggregate productivity index which incorporates technological changes, recent innovations, etc., in the production of $Y_{i t}$. In this general specification, any improvement in $\mathrm{P}_{\text {it }}$, perhaps due to improvements in IC conditions, represents a movement along the production function as well as a shift of the production function.
} 


\section{Econometric Methodologies for Investment Climate Assessments on Productivity}

The next step is to discuss the advantages and disadvantages of using alternative measures of productivity for the evaluation of the impact of IC variables on productivity. From the above discussion is clear that we have two general approaches to measure productivity P:

a)

based on the rate of growth of P using equations (3a) and (3b); or

b) based on the level (or logs) of P obtained from equations (2a) and (2b).

Which of the two approaches is more general or more convenient to evaluate the impact of IC variables on productivity? To answer this question we must study the conditions (Hicks neutral technical change, competitive inputs markets, constant returns to scale, constant input elasticities, no measurement errors in the variables, time dimension of the sample, balanced panel data, etc.) that are behind each of the measures or estimations of $\mathrm{P}$ and to determine whether those conditions are satisfied in the cases of Guatemala, Honduras and Nicaragua. If some of them are not satisfied we should search for productivity measures that are robust to the impact of IC variables.

\section{Productivity Measures Based on Rates of Growth}

At first glance, the procedure based on rates of growth seems to be more general because it does not require us to specify a particular functional form of the production function $\mathrm{F}(\mathrm{L}, \mathrm{M}, \mathrm{K})$. However, it has serious drawbacks arising from the quality of the data

$d \log Y_{i t}=\frac{\partial \log F_{i t}}{\partial L_{i t}} d L_{i t}+\frac{\partial \log F_{i t}}{\partial M_{i t}} d M_{i t}+\frac{\partial \log F_{i t}}{\partial K_{i t}} d K_{i t}+\frac{\partial \log F_{i t}}{\partial P_{i t}} d P_{i t}$.

If the "residual" or the weighted rate of growth of $\mathrm{P}_{\mathrm{it}}$, which is $\frac{\partial \log F_{i t}}{\partial P_{i t}} d P_{i t}=\alpha_{P, i t} d \log P_{i t}$, has elasticity $\alpha_{P, i t}=1$ then $d \log \mathrm{P}_{\mathrm{it}}=\mathrm{d} \log \mathrm{TFP} \mathrm{P}_{\mathrm{it}}$, where TFP refers to the Total Factor Productivity. However, when the separability conditions (Hicks neutral technical, etc.) are not satisfied, see Jorgenson, Gollop and Fraumeni (1987), what we are measuring by the "residual" is the rate of growth of productivity as a time varying weighted rate of growth of $\mathrm{P}_{\mathrm{it}}$ and this might not be equal to the rate of growth of TFP. As we will see in the empirical section, those conditions are difficult to satisfy in most countries. So we call the "residual" productivity (P) and not TFP. Our productivity (P) concept is sometimes called multifactor productivity. 


\section{Econometric Methodologies for Investment Climate Assessments on Productivity}

(measurement errors and missing observations) and the goal of the analysis (long run versus short run), as will soon become clear.

Differentiating totally the expressions $d \log Q_{i t}=d \log F\left(L_{i t}, M_{i t}, K_{i t}\right)$ and $d \log G\left(\mathrm{IC}_{i t}, C_{i t}\right)$ from equations (3a) and (3b) we get:

$$
\begin{gathered}
d \log Y_{i t}=\frac{\partial \log F_{i t}}{\partial L_{i t}} d L_{i t}+\frac{\partial \log F_{i t}}{\partial M_{i t}} d M_{i t}+\frac{\partial \log F_{i t}}{\partial K_{i t}} d K_{i t}+d \log P_{i t} \\
d \log P_{i t}=\frac{\partial \log G_{i t}}{\partial I C_{i t}} d I C_{i t}+\frac{\partial \log G_{i t}}{\partial C_{i t}} d C_{i t}+d u_{i t}
\end{gathered}
$$

which can be written in term of their rates of growth ${ }^{5}$ as:

$$
\begin{gathered}
d \log Y_{i t}=\alpha_{L, i t} d \log L_{i t}+\alpha_{M, i t} d \log M_{i t}+\alpha_{K, i t} d \log K_{i t}+d \log P_{i t} \\
d \log P_{i t}=\alpha_{I C, i t} d \log I C_{i t}+\alpha_{C, i t} d \log C_{i t}+d u_{i t}
\end{gathered}
$$

where the coefficients of equation ${ }^{6}(5 a) \alpha_{j}$,it are the j-input-elasticities of the aggregate input $\mathrm{Q}, \mathrm{j}=\mathrm{L}, \mathrm{M}$, and $\mathrm{K}$, of firm (i) in period ( $\mathrm{t}$ ) defined as ${ }^{7}$ :

$$
\begin{aligned}
& \alpha_{L, i t}=\frac{L_{i t}}{F_{i t}} \frac{\partial F_{i t}}{\partial L_{i t}}=\frac{\partial \log Q_{i t}}{\partial \log L_{i t}}, \\
& \alpha_{M, i t}=\frac{M_{i t}}{F_{i t}} \frac{\partial F_{i t}}{\partial M_{i t}}=\frac{\partial \log Q_{i t}}{\partial \log M_{i t}} \\
& \alpha_{K, i t}=\frac{K_{i t}}{F_{i t}} \frac{\partial F_{i t}}{\partial K_{i t}}=\frac{\partial \log Q_{i t}}{\partial \log K_{i t}} .
\end{aligned}
$$

\footnotetext{
${ }^{5}$ Notice that we are assuming that IC and C variables are scalar and not vectors. This is done in this section to simplify the notation. In the empirical application we will consider that both are vectors.

${ }^{6}$ The coefficients of (5b) are also elasticities and are defined in a similar way.

${ }^{7}$ If the technical progress is not Hicks neutral (see footnote 3 ) then the residual from equation ( $\left.5 \mathrm{a}\right) \operatorname{dlog} \mathrm{P}_{\mathrm{it}}$ is not equal to dlogTFP it but equal to $\alpha_{\mathrm{P}, \mathrm{it}} \operatorname{dlog} \mathrm{P}_{\mathrm{it}}$.
} 


\section{Econometric Methodologies for Investment Climate Assessments on Productivity}

Comment: Equation (5a) is useful to isolate the types of variables that should be included if we want to explain the evolution of labor productivity growth, $d \log (\mathrm{Y} / \mathrm{L})=\mathrm{d} \log \mathrm{Y}-\mathrm{d} \log \mathrm{L}$ :

$$
d \log \left(Y_{i t} / L_{i t}\right)=\left(\alpha_{L, i t}-1\right) d \log L_{i t}+\alpha_{M, i t} d \log M_{i t}+\alpha_{K, i t} d \log K_{i t}+d \log P_{i t} .
$$

It is not uncommon to see regression equations estimating labor productivity that omit the variable capital stock $(\mathrm{K})$. The capital stock, or its rate of growth, should always be there (if available) and productivity (P) can be substituted by its determinants, say the variables (IC and $\mathrm{C}$ ) of equation (5b), to avoid the simultaneous equation bias.

Before proceeding to obtain empirical measures of productivity $(\mathrm{P})$, two problems must be faced:

First. We have to approximate the continuous transformation of the variables, say $\operatorname{dlog}\left(\mathrm{Y}_{\mathrm{it}}\right)$, by a discrete approximation based on first differences, say $\Delta \log \left(\mathrm{Y}_{\mathrm{it}}\right)=\log \left(\mathrm{Y}_{\mathrm{i}, \mathrm{t}}\right)-\log \left(\mathrm{Y}_{\mathrm{i}, \mathrm{t}-1}\right)$. This last approximation requires transforming (5a,) using the Tornqvist ${ }^{8}(1936)$ index:

$$
\Delta \log Y_{i t}=\bar{\alpha}_{L, i t} \Delta \log L_{i t}+\bar{\alpha}_{M, i t} \Delta \log M_{i t}+\bar{\alpha}_{K, i t} \Delta \log K_{i t}+\Delta \log P_{i t}
$$

where $\bar{\alpha}_{j, i, t}=\frac{1}{2}\left(\alpha_{j, i, t}+\alpha_{j, i, t-1}\right)$ is average input-output elasticity of input $\mathrm{j}$ of firm i during the last two years ( $t$ and $t-1$ ) where $j=L_{i t}, M_{i t}$ and $K_{i t}$.

Second. The input-output elasticities $\alpha_{\mathrm{j}, \text { it }}$ are unknown and therefore they have to be measured by nonparametric procedures, index number techniques (see Diewert and Nakamura 2002) or estimated by regression techniques, assuming that the elasticity parameters are constant in some sense (by industry, by country, etc.).

\footnotetext{
${ }^{8}$ Jorgenson and Griliches (1967), among others, suggested to use this Tornqvist index as an approximation to the continuous Divisia index.
} 
To understand the advantages and disadvantages of the several options available when measuring productivity or productivity growth, we should study the underlying conditions and restrictions behind each option. For the ease and clarity of the discussion we introduce now the complete list of assumptions. Later on, when discussing each option, we will explicitly indicate the particular assumptions required for each productivity measure.

\section{List of conditions for productivity growth measures}

Assumption 3.1: The elasticity parameters $\bar{\alpha}_{j, i, t}=\bar{\alpha}_{j, i}=\alpha_{j, i}$ are constant at time $\mathrm{t}$ (time invariant) and constant for some of the i-firms (say $\alpha_{j, i}=\alpha_{j}$ constant for those $\mathrm{i}$-firms that belong to the same industry $\mathrm{j}$, the same region of a country, or the same country, etc.). Assumption 3.2: The rates of growth of the inputs L, M and $\mathrm{K}$ are strictly exogenous ${ }^{9}$ in equation (8).

Assumption 3.3: The rates of growth of the IC and $\mathrm{C}$ are strictly exogenous in equation (9). Assumption 3.4: The rates of growth of the inputs L, M and $\mathrm{K}$ and the rates of growth of the IC, CU and C are strictly exogenous in equation (10).

Assumption 3.5: The technology of $\mathrm{F}(\mathrm{L}, \mathrm{M}, \mathrm{K})$ has constant returns to scale (CRS).

Assumption 3.6: The input markets are competitive.

Assumption 3.7: The product markets are competitive.

\section{Option 3.1: Two-step regression estimation approach}

Under assumptions 3.1 and 3.2, and other statistical regularity conditions, ordinary least squares (OLS) provides consistent and unbiased estimators of those constant elasticities based on a two-step regression approach.

\footnotetext{
${ }^{9}$ The rate of growth of the inputs $\left(\Delta \mathrm{L}_{\mathrm{i}}, \Delta \mathrm{M}_{\mathrm{i}}, \Delta \mathrm{K}_{\mathrm{i}}\right)$ of firm $\mathrm{i}$ are strictly exogenous if the actual rates of growth $\left(\Delta \mathrm{L}_{\mathrm{it}}, \Delta \mathrm{M}_{\mathrm{it}}, \Delta \mathrm{K}_{\mathrm{it}}\right)$ as well as the past $\left(\Delta \mathrm{L}_{\mathrm{it}-\mathrm{j}}, \Delta \mathrm{M}_{\mathrm{it}-\mathrm{j},}, \Delta \mathrm{K}_{\mathrm{it}-\mathrm{j}}\right)$ and future $\left(\Delta \mathrm{L}_{\mathrm{it} \mathrm{j}}, \Delta \mathrm{M}_{\mathrm{it}+\mathrm{j}}, \Delta \mathrm{K}_{\mathrm{it}+\mathrm{j}}\right)$ rates of growths are uncorrelated with the $\Delta \mathrm{P}_{\text {it }}$ for all $\mathrm{j}$.
} 
In the first step, the rate of growth of $\mathrm{P}$ is obtained as the residuals ( $\Delta \log P)$ from regression (8):

$$
\Delta \log Y_{i t}=\hat{\alpha}_{L, j} \Delta \log L_{i t}+\hat{\alpha}_{M, j} \Delta \log M_{i t}+\hat{\alpha}_{K, j} \Delta \log K_{i t}+\Delta \log P_{i t}
$$

In the second step, we estimate regression (9), under assumption 3.3:

$$
\Delta \log P_{i t}=\hat{\alpha}_{I C, j} \Delta \log I C_{i t}+\hat{\alpha}_{C, j} \Delta \log C_{i t}+\Delta \hat{u}_{i t}
$$

\section{Estimation issues that need to be addressed}

We will discuss now the problems found when estimating constant input-output elasticities and the impact of IC variables when productivity is in rates of growth:

i) Elasticity parameter estimates in levels (with integrated of order 1 variables, I(1)) and in differences (with $\mathrm{I}(0)$ variables) might give different parameter estimates since in growing economies the short run elasticities are different from the long-run elasticities, unless a common factor restriction is satisfied. (See for example Escribano and Granger 1998). This problem is also relevant in panel data when we have a panel which is long in the time dimension (T). (See Im, Pesaran and Shin 2003; Escribano and Pena 2004.) Obviously, this is not an issue here since we only have observations from two consecutive years.

ii) Equation (9) in differences implies that the errors $\left(\mathrm{u}_{i t}\right)$ of equation $(2 \mathrm{~b})$ in levels (or in $\operatorname{logs}$ ) are $\mathrm{I}(1)$. Otherwise, the error $\Delta \mathrm{u}_{\mathrm{it}}$ from (9) will be serially correlated.

iii) If the regression variables are measured with errors their impact is enhanced by taking first differences.

iv) Assumption 3.2 or the strictly exogenous condition of regressors in equation (8) is almost never satisfied in this case, since the explanatory variables of the production function 
$(\mathrm{L}, \mathrm{M}, \mathrm{K})$ in (8) are endogenous.(See Marshak and Andrews 1944.) This simultaneous equation problem implies that least square estimators are not consistent and are biased and usually require the use of instrumental variables (IV). However, equations with variables in differences suffer from the weak instruments problem which produces very poor parameter estimates. (Chamberlain 1982; Griliches and Mairesse 1995.) This problem is transferred to the second step when estimating the impact of the IC variables based on inconsistent and biased rates of growth of $\mathrm{P}$, which is the dependent variable of equation (9).

v) Another difficulty in applying this approach to our data set from Guatemala, Honduras and Nicaragua, is that we have information on the IC variables for only one year so we cannot compute the rates of growth of IC variables.

vi) Equation (9) assumes that the elasticities are constant through time. This problem is partially solved if we allow the variables to enter nonlinearly (as in the Translog production function, etc.) This option will be discussed later.

The following option 3.2, based on a one-step approach, solves under certain conditions problem iv) but still faces the other drawbacks.

\section{Option 3.2: One-step regression estimation approach}

If we have information on IC variables at the firm level for more than one year, we can mitigate problem iv) if equations (8) and (9) are jointly estimated. That is, when $\Delta \log P_{i t}$ is correlated with inputs $\Delta \log L_{i t}, \Delta \log M_{i t}, \Delta \log K_{i t}$, assumption 3.2 fails. However since this simultaneous equation bias comes from the IC and $\mathrm{C}$ variables at the firm level we can estimate all the parameters in regression (10), provided that the weaker assumption 3.4 is satisfied: 


$$
\begin{aligned}
\Delta \log Y_{i t}= & \hat{\alpha}_{L, j} \Delta \log L_{i t}+\hat{\alpha}_{M, j} \Delta \log M_{i t}+\hat{\alpha}_{K, j} \Delta \log K_{i t}+ \\
& +\hat{\alpha}_{I C, j} \Delta \log I C_{i t}+\hat{\alpha}_{C, j} \Delta \log C_{i t}+\Delta \hat{u}_{i t} .
\end{aligned}
$$

Under assumption 3.4, $\Delta \mathrm{u}_{\mathrm{it}}$ is uncorrelated with the regressors of (10) and OLS estimation provides consistent estimates of the unknown constant elasticities. The rate of growth of $\mathrm{P}$ is therefore generated from some of the estimated parameter values of equation (10)

$$
\Delta \log P_{i t}=\Delta \log Y_{i t}-\hat{\alpha}_{L, j} \Delta \log L_{i t}-\hat{\alpha}_{M, j} \Delta \log M_{i t}-\hat{\alpha}_{K, j} \Delta \log K_{i t} .
$$

We have seen that under the weaker assumption 3.4 we can solve the simultaneous equation bias of the two-step estimation procedure. However, we still have to face the other four drawbacks mentioned at the end of option 3.1.

In the following option, we discuss an alternative two-step approach that avoids the simultaneous equation bias, when the variables are not exogenous.

\section{Option 3.3: Nonparametric growth accounting procedures (Solow's residual)}

What options do we have if we are not willing to assume that the input-output elasticities are constant (assumption 3.1) or that they are strictly exogenous?

Under assumption 3.5 the marginal cost of the firm is equal to the average cost. Furthermore, this condition allows us to consider general functional forms of the production function $\mathrm{F}(\mathrm{L}, \mathrm{M}, \mathrm{K})$ like a Translog, but we have to impose certain parameter constraints to satisfy the CRS condition.

Under assumption 3.6, firms are price takers in the inputs markets because, say, input prices are determined by the market equilibrium. However, this condition allows some degree of 
product market imperfections and firms can have market power, which is a likely possibility in most industries of Guatemala, Honduras and Nicaragua given that the number of firms in some industries is small.

Under assumptions 3.5 and 3.6, we can use growth accounting techniques to estimate the rate of growth of TFP while allowing the input-output elasticities $\bar{\alpha}_{j, i, t}$ to be nonconstant (time varying and heterogeneous). The reason is that under those conditions, the elasticities $\alpha_{j, i, t}$ are equal to the observable $\mathrm{j}$-input shares $\left(\mathrm{s}_{\mathrm{j}, \mathrm{it}}\right)$ of the $\mathrm{i}$-firm in year $t$, relative to the total cost, where $\mathrm{j}=\mathrm{L}_{\mathrm{it}}, \mathrm{M}_{\mathrm{it}}$ and $\mathrm{K}_{\mathrm{it}}$ are the three inputs. That is,

$$
\begin{aligned}
& \alpha_{L, i t}=\frac{L_{i t}}{Q_{i t}} \frac{\partial F}{\partial L_{i t}}=\frac{w_{t} L_{i t}}{\left(w_{t} L_{i t}+c_{t} M_{i t}+r_{t} K_{i t}\right)}=s_{L, i t} \\
& \alpha_{M, i t}=\frac{M_{i t}}{Q_{i t}} \frac{\partial F}{\partial M_{i t}}=\frac{c_{t} M_{i t}}{\left(w_{t} L_{i t}+c_{t} M_{i t}+r_{t} K_{i t}\right)}=s_{M, i t} \\
& \alpha_{K, i t}=\frac{K_{i t}}{Q_{i t}} \frac{\partial F}{\partial K_{i t}}=\frac{r_{t} k_{i t}}{\left(w_{t} L_{i t}+c_{t} M_{i t}+r_{t} K_{i t}\right)}=s_{K, i t}
\end{aligned}
$$

Once we have a measure of the time varying input-output elasticities, $\mathrm{s}_{\mathrm{j}, \mathrm{i}, \mathrm{t}}$, we can obtain TFP from equation (7) as a residual from the following growth accounting exercise at the firm level:

$$
\Delta \log T F P_{i t}=\Delta \log Y_{i t}-\bar{s}_{L, i t} \Delta \log L_{i t}-\bar{s}_{M, i t} \Delta \log M_{i t}-\bar{s}_{K, i t} \Delta \log K_{i t}
$$

where the average cost shares from the last two periods are given by, $\bar{s}_{j, i, t}=\frac{1}{2}\left(s_{j, i, t}+s_{j, i, t-1}\right)$ for $\mathrm{j}=\mathrm{L}, \mathrm{M}$ and $\mathrm{K}$, following Tornqvist (1936).

This measure of the rate of growth of TFP is usually called the Solow residual (SR), and follows the approach suggested by Hall (1990). If assumptions 3.5 and 3.6 fail, for example there are no CRS, then what we get from using (13) is again a measure of productivity $\mathrm{P}$, 
which is the productivity not explained by L,M and K, but it is not equal to the rate of growth of TFP associated with shifts of the production function.

However Solow's original proposal, see Solow (1957), was based on assumptions 3.5, 3.6 and 3.7 and used an alternative growth accounting technique to estimate TFP where the inputoutput elasticities $\bar{\alpha}_{j, i, t} \alpha_{j, i, t}$ were equal to the $\mathrm{j}$-input shares relative to income ( $\left.\mathrm{ys}_{\mathrm{j}, \mathrm{it}}\right)$ where $\mathrm{j}$ $=\mathrm{L}, \mathrm{M}$ and $\mathrm{K}$.

Under assumptions 3.6 and 3.7, each input is paid the value of its marginal product and we have that $P_{i t} \frac{\partial F}{\partial L_{i t}}=w_{t}, P_{i t} \frac{\partial F}{\partial K_{i t}}=c_{t}$ and $P_{i t} \frac{\partial F}{\partial K_{i t}}=r_{t}$ where $P_{i t}$ is the competitive market price of output $\mathrm{i}$ at time t. From direct substitution in equation (6) we get a measure of the unknown elasticities with the $\mathrm{j}$-input share relative to income $\left(y s_{j, i t}\right)$ for $\mathrm{j}=\mathrm{L}, \mathrm{M}$ and $\mathrm{K}$,

$$
\alpha_{L, i t}=\frac{w_{t} L_{i t}}{P_{i t} Q_{i t}}=y s_{L, i t}, \alpha_{M, i t}=\frac{c_{t} M_{i t}}{P_{i t} Q_{i t}}=y s_{M, i t} \text { and } \alpha_{K, i t}=\frac{r_{t} K_{i t}}{P_{i t} Q_{i t}}=y s_{K, i t} \text {. }
$$

Substituting those new shares in equation (7) we get the Solow residual (SR): the residual growth rate of output not explained by the growth in inputs, measured as

$$
\Delta \log T F P_{i t}=\Delta \log Y_{i t}-y \bar{s}_{L, i t} \Delta \log L_{i t}-y \bar{s}_{M, i t} \Delta \log M_{i t}-y \bar{s}_{K, i t} \Delta \log K_{i t}
$$

but with the average income shares from the last two periods, using $y \bar{s}_{j, i, t}=\frac{1}{2}\left(y s_{j, i, t}+y s_{j, i, t-1}\right)$ for $\mathrm{j}=\mathrm{L}, \mathrm{M}$ and $\mathrm{K}$. Solow (1957) considered also assumption 3.5 on (CRS) to avoid having to compute the user cost of capital $\left(\mathrm{r}_{\mathrm{t}}\right)$ in each year. That is, under CRS, $y \bar{S}_{K, i t}=1-y \bar{S}_{L, i t}-y \bar{s}_{M, i t}$.

Notice that the Solow residuals of firm (i) in period (t), obtained either from (13) or (14), are true non-parametric index numbers since they are obtained directly from observed prices and 
quantities under some conditions on the existence of competitive markets. No statistical parameter estimation is required to obtain the Solow residuals and therefore we can measure nonparametrically time varying elasticities avoiding any possible simultaneous equation estimation bias.

The question of interest when comparing these two alternative measuring procedures is whether starting from (13) or (14) we get the true efficiency parameter $\left(\mathrm{TFP}_{\mathrm{it}}\right.$ ) of the production. (See footnote 3.) If any of the assumptions fails (say there is no CRS, no Hicks neutral technical change or there is no competitive inputs market) what we get from equations (13) and (14) is a measure of the rate of growth of productivity $\left(\Delta \log \mathrm{P}_{\text {it }}\right)$ but this is not equal to the rate of growth of TFP $\left(\triangle \log T F P_{i t}\right)$. Therefore, in the empirical applications, we should interpret the influence of IC variables on P and not the influence on TFP, unless all the assumption 3.5, 3.6 and 3.7 are satisfied, which is usually not the case in developing countries.

Once we have a measure of the rate of growth of productivity $\left(\mathrm{P}_{\mathrm{it}}\right)$ using (13) or (14), we could, in the second step, estimate regression (9) under assumptions 3.1 on the parameters of (9) and assumption 3.3, getting a consistent estimator of the impact of IC variables on the rate of growth of productivity $\left(\Delta \log P_{i t}\right)$.

In summary, the analysis based on productivity growth is more general since it does not require to specify the functional form of the production function, but for it to be appropriate the quality of the data should be very good (no weak instruments, no short time dimension nor unbalance panel data, more than one year of data on investment climate variables, etc). Given these remarks (see also comments iii to iv at the end of option 3.1) and the basic characteristics of our data base, we prefer to undertake the productivity analysis based on the levels or the logs of the variables, as discussed in the next section.

\section{Alternative Productivity Measures based on Variables in Levels}


The goal here is to estimate the input-output elasticities based on the levels of the variables and not on their rates of growth. Once we have the productivity growth obtained from equation (5a) we could obtain the levels (or logs), by integrating ${ }^{10}$ equation ( $\left.5 \mathrm{a}\right)$ to get:

$$
\sum_{t=1}^{T} \Delta \log Y_{i t}=\sum_{t=1}^{T} \alpha_{L, i t} \Delta \log L_{i t}+\sum_{t=1}^{T} \alpha_{M, i t} \Delta \log M_{i t}+\sum_{t=1}^{T} \alpha_{K, i t} \Delta \log K_{i t}+\sum_{t=1}^{T} \Delta \log P_{i t} .
$$

The last terms of (15), $\sum_{t=1}^{T} \Delta \log P_{i t}$, can be written as the constant of integration (that depends on the initial conditions of firm $\mathrm{i}$, say $\left.\log \mathrm{P}_{\mathrm{i} 0}\right)$ and $\log \tilde{P}_{\text {іт. }}$. A similar expression is obtained for the term on LHS of the equation, $\sum_{t=1}^{T} \Delta \log Y_{i t}$. The rest of the terms in (15) have weights, say $\sum_{t=1}^{T} \alpha_{L, i t} \Delta \log L_{i t}$. They can be decomposed as the constant of integration of firm i (say $\log \mathrm{L}_{i 0}$ ), the $\log \mathrm{L}_{\mathrm{iT}}$, and the extra terms $\sum_{t=2}^{T} \Delta \alpha_{L, t} \log L_{i t-1}$. Therefore, from equation (15) we have:

$$
\begin{aligned}
\log Y_{i T}= & \alpha_{L, i T} \log L_{i T}+\alpha_{M, i T} \log M_{i T}+\alpha_{K, i T} \log K_{i T}+\log \tilde{P}_{i T} \\
& +\log P_{i 0}-\sum_{t=1}^{T-1} \Delta \alpha_{L, i t} \log L_{i t-1}-\sum_{t=1}^{T-1} \Delta \alpha_{M, i t} \log M_{i t-1}-\sum_{t=1}^{T-1} \Delta \alpha_{K, i t} \log K_{i t-1} .
\end{aligned}
$$

From the elements of equation (16) it is clear that if we generate the broad concept of productivity $P_{i t}$ as the residual of equation (17),

$$
\log Y_{i t}=\alpha_{L, i t} \log L_{i t}+\alpha_{M, i t} \log M_{i t}+\alpha_{K, i t} \log K_{i t}+\log P_{i t}
$$

\footnotetext{
${ }^{10}$ See Escribano and Pena(2004) for a detailed derivation of these results and for an empirical robust analysis based on a long time dimension data set.
} 


\section{Econometric Methodologies for Investment Climate Assessments on Productivity}

$\log P_{\text {it }}$ includes $\log \tilde{P}_{\text {it }}$, a firm specific initial condition term $\left(\log P_{i 0}\right)$ but also the sum of the cross-product terms $-\Delta \alpha_{J, i t} \log J_{i t-1}$, for each of the three inputs $\mathrm{J}=\mathrm{L}, \mathrm{M}$ and $\mathrm{K}$. Therefore, in general we cannot associate the residual of (17) with $\log \mathrm{TFP}_{\text {it }}$ unless certain restrictive conditions from (16) and (5a) are satisfied and purpose of this section is to evaluate those conditions.

To understand the advantages and disadvantages of the several options available when measuring productivity in levels (logs), we should study the underlying conditions and restrictions that are behind each option. For the ease and clarity of the discussion we introduce now the complete list of assumptions. Later on, when discussing each option we will explicitly indicate the particular set of assumptions required for each productivity measure.

\section{List of conditions for productivity measures}

Assumption 4.1: The elasticity parameters $\bar{\alpha}_{j, i, t}=\bar{\alpha}_{j, i}=\alpha_{j, i}$ are constant in time $\mathrm{t}$ (time invariant) and constant for some of the i-firms (say $\alpha_{j, i}=\alpha_{j}$ constant for those i-firms that belong to the same industry $\mathrm{j}$, or the same region of a country, or the same country, etc.). Assumption 4.2: The levels or logs of the inputs L,M and $\mathrm{K}$ are strictly exogenous ${ }^{11}$ in equation (17).

Assumption 4.3: The levels or logs of the IC and $\mathrm{C}$ are strictly exogenous in equation (17b). Assumption 4.4: The levels or logs of the inputs L,M and $\mathrm{K}$ and the levels or logs of the IC and $\mathrm{C}$ are strictly exogenous in equation (26).

Assumption 4.5: The technology of $\mathrm{F}(\mathrm{L}, \mathrm{M}, \mathrm{K})$ has constant returns to scale (CRS).

Assumption 4.6: The input markets are competitive.

Assumption 4.7: The product markets are competitive.

Assumption 4.8

\footnotetext{
${ }^{11}$ The $\log$ of the inputs $\left(\log \mathrm{L}_{\mathrm{i}}, \log \mathrm{M}_{\mathrm{i}}, \log \mathrm{K}_{\mathrm{i}}\right)$ of firm $\mathrm{i}$ are strictly exogenous if the contemporaneous values $\left(\log \mathrm{L}_{\mathrm{it}}\right.$, $\left.\log \mathrm{M}_{\mathrm{it}}, \log \mathrm{K}_{\mathrm{it}}\right)$ as well as the past values $\left(\log \mathrm{L}_{\mathrm{it}-\mathrm{j}}, \log \mathrm{M}_{\mathrm{it}-\mathrm{j}}, \log \mathrm{K}_{\mathrm{it}-\mathrm{j}}\right)$ and future values $\left(\log \mathrm{L}_{\mathrm{it}+\mathrm{j}}, \log \mathrm{M}_{\mathrm{it}+\mathrm{j}}, \log \mathrm{K}_{\mathrm{it}+\mathrm{j}}\right)$ are uncorrelated with the $\mathrm{P}_{\mathrm{it}}$ for all $\mathrm{j}$.
} 


$$
\sum_{t=1}^{T-1} \Delta \alpha_{L, i t} \log L_{i t-1}+\sum_{t=1}^{T-1} \Delta \alpha_{M, i t} \log M_{i t-1}+\sum_{t=1}^{T-1} \Delta \alpha_{K, i t} \log K_{i t-1}=0 \text { in equation (16) }
$$

Assumption 4.9

$$
\sum_{t=1}^{T} \tilde{\alpha}_{L, i t} \Delta \log L_{i t}+\sum_{t=1}^{T} \tilde{\alpha}_{M, i t} \Delta \log M_{i t}+\sum_{t=1}^{T} \tilde{\alpha}_{K, i t} \Delta \log K_{i t}=0 \text { in equation (25). }
$$

Under assumption 4.1, the input-output elasticities are constant (time invariant) $\Delta \alpha_{r, i t}=0$ for all $\mathrm{r}=\mathrm{L}, \mathrm{M}$ and $\mathrm{K}$, and therefore, for any functional form of the production function $\mathrm{F}(\mathrm{L}, \mathrm{M}, \mathrm{K})$ in (1a) with constant elasticities, equation (16) is reduced to

$$
\log Y_{i t}=\alpha_{L, j} \log L_{i t}+\alpha_{M, j} \log M_{i t}+\alpha_{K, j} \log K_{i t}+\log P_{i 0}+\log \tilde{P}_{i t}
$$

Alternatively, under assumption 4.8, equation (16) is reduced to (19) with time-varying inputoutput elasticities:

$$
\log Y_{i t}=\alpha_{L, i t} \log L_{i t}+\alpha_{M, i t} \log M_{i t}+\alpha_{K, i t} \log K_{i t}+\log P_{i 0}+\log \tilde{P}_{i t} .
$$

Now, $\log P_{i t}=\log P_{i 0}+\log \tilde{P}_{i t}$ of equations (18) and (19) should be closer to $\log \mathrm{TFP}_{\text {it. }}$

However, estimating productivity $(\mathrm{P})$ in levels $(\operatorname{logs})$ it is common to specify a parametric functional form for $\mathrm{F}(\mathrm{L}, \mathrm{M}, \mathrm{K})$ which is usually of Cobb-Douglas type. It is clear that the Cobb-Douglas specification with constant input-output elasticities satisfies assumption 4.1. But we might have a Cobb-Douglas specification without constant elasticities, as in equations (20a), (20b) or (21a) and (21b) below. When both the production function F(L,M,K) and the nonlinear function G(IC, C) from (1a) and (1b) respectively, are Cobb-Douglas they can be written as:

$$
\begin{gathered}
Y_{i t}=\left(L_{L_{i t}}^{\alpha_{L, i t}} M_{M_{i t}}^{\alpha_{M, i t}} K_{K_{i t}}^{\alpha_{K, i t}}\right) P_{i t} \\
\mathrm{P}_{\mathrm{it}}=\left(A_{P} I C_{I C_{i t}, i t}^{\alpha_{I C}} C_{C_{i t}}^{\alpha_{C, i t}}\right) \exp \left(\mathrm{u}_{\mathrm{it}}\right) .
\end{gathered}
$$


Taking logarithms and calling $\log A_{p}=\alpha_{P}$. we can write (20a) and (20b) as:

$$
\begin{gathered}
\log Y_{i t}=\alpha_{L, i t} \log L_{i t}+\alpha_{M, i t} \log M_{i t}+\alpha_{K, i t} \log K_{i t}+\log P_{i t} \\
\log P_{i t}=\alpha_{I C, i t} \log I C_{i t}+\alpha_{C, i t} \log C_{i t}+\alpha_{P}+u_{i t} .
\end{gathered}
$$

Once again, the interpretation of the time variant coefficients is similar. For equation (21a) we have the time varying $\mathrm{j}$-input-output elasticities, $\alpha_{\mathrm{j}, \text { it }}$, where $\mathrm{j}=\mathrm{L}, \mathrm{M}$, and $\mathrm{K}$ for firm (i) in period $(\mathrm{t})$ defined as:

$$
\alpha_{L, i t}=\frac{\partial \log Y_{i t}}{\partial \log L_{i t}}, \alpha_{M, i t}=\frac{\partial \log Y_{i t}}{\partial \log M_{i t}} \text { and } \alpha_{K, i t}=\frac{\partial \log Y_{i t}}{\partial \log K_{i t}}
$$

and the coefficients of equation (21b) $\alpha_{j}$,it are the elasticities of $P$ with respect to the $j$ variable where $\mathrm{j}=\mathrm{IC}$ and $\mathrm{C}$ for firm (i) in period ( $\mathrm{t}$ ) defined as:

$$
\alpha_{I C, i t}=\frac{\partial \log P_{i t}}{\partial \log I C_{i t}}, \alpha_{C U, i t}=\frac{\partial \log P_{i t}}{\partial \log C U_{i t}} \text { and } \alpha_{K, i t}=\frac{\partial \log P_{i t}}{\partial \log C_{i t}} \text {. }
$$

If the parametric functional form of the production function $\mathrm{F}(\mathrm{L}, \mathrm{M}, \mathrm{K})$ is Translog, equation (21a) becomes:

$$
\begin{aligned}
& \log Y_{i t}=\alpha_{L, i t} \log L_{i t}+\alpha_{M, i t} \log M_{i t}+\alpha_{K, i t} \log K_{i t}+ \\
& \quad+\frac{1}{2} \alpha_{L L, i t}\left(\log L_{i t}\right)^{2}+\frac{1}{2} \alpha_{M M, i t}\left(\log M_{i t}\right)^{2}+\frac{1}{2} \alpha_{K K, i t}\left(\log K_{i t}\right)^{2}+ \\
& \quad+\alpha_{L M, i t}\left(\log L_{i t}\right)\left(\log M_{i t}\right)+\alpha_{L K, i t}\left(\log L_{i t}\right)\left(\log K_{i t}\right)+\alpha_{M K, i t}\left(\log M_{i t}\right)\left(\log K_{i t}\right)+ \\
& \quad+\log P_{i t} .
\end{aligned}
$$

Alternatively, from equation (15) we can get an expression inspired in Olley and Pakes' (1996) decomposition (see also section 4) with the summations running through time instead 
of across the i-firms in a particular year. Let $\bar{\alpha}_{J, i}=\frac{1}{T} \sum_{t=1}^{T} \alpha_{J, i t}$ and $\Delta \log J_{i}=\frac{1}{T} \sum_{t=1}^{T} \Delta \log J_{i t}$ for $\mathrm{J}=\mathrm{L}, \mathrm{M}$ and $\mathrm{K}$ be the corresponding sample averages. Then each of the first three elements of the RHS of equation (15) can be decomposed as:

$$
\sum_{t=1}^{T} \alpha_{J, i t} \Delta \log J_{i t}=\sum_{t=1}^{T}\left[\bar{\alpha}_{J, i}+\tilde{\alpha}_{J, i t}\right]\left[\Delta \log J_{i}+\Delta \log J_{i t}\right]
$$

where $\tilde{\alpha}_{J, i t}=\left(\alpha_{L, i t}-\bar{\alpha}_{J, i}\right)$ and $\Delta \log J_{i t}=\left(\Delta \log J_{i t}-\Delta \log J_{i}\right)$. Simplifying equation (15) using this decomposition we get

$$
\begin{aligned}
\log Y_{i T}= & \bar{\alpha}_{L, i} \log L_{i T}+\bar{\alpha}_{M, i} \log M_{i T}+\bar{\alpha}_{K, i} \log K_{i T}+\log P_{i T}+ \\
& + \text { const }_{i 0}+\sum_{t=1}^{T} \tilde{\alpha}_{L, i t} \Delta \log L_{i t}+\sum_{t=1}^{T} \tilde{\alpha}_{M, i t} \Delta \log M_{i t}+\sum_{t=1}^{T} \tilde{\alpha}_{K, i t} \Delta \log K_{i t} .
\end{aligned}
$$

Under assumption 4.1 the input-output elasticities are constant, and $\tilde{\alpha}_{J, i t}=\left(\alpha_{L, i t}-\bar{\alpha}_{J, i}\right)=0$ for $\mathrm{J}=\mathrm{L}, \mathrm{M}$ and $\mathrm{K}$ and equation (25) is reduced to equation (18).

Assumption 4.9 establishes the necessary condition for the productivity $\left(\mathrm{P}_{\mathrm{it}}\right)$ estimated as the residual from equation (18), to be equal to the one generated by (24). For example if the Cobb-Douglas specification is rejected in favor of a Translog specification we should expect assumption 4.8 and/or assumption 4.9 to fail. (See Escribano and Pena 2004). 


\section{Option 4.1: Two-step regression approach}

Under assumptions 4.1 and $4.2, \log \mathrm{P}_{\mathrm{it}}$ is uncorrelated with the inputs $\log \mathrm{L}_{\mathrm{it}}, \log \mathrm{M}_{\mathrm{it}}$ and $\log \mathrm{K}_{\mathrm{it}}$, in equation (2a), we can estimate (first step) those constant elasticity parameters in (18) by least squares regression techniques ${ }^{12}$ and the residuals will be the estimates of the logarithm of TFP, $\log T F P_{i t}$, see equation (25a). Under assumption 4.3, we can consistently estimate the impact of the IC variables on TFP by estimating (second-step) equation (21b) by least squares using as dependent variable loĝTFP $P_{i t}$, see equation $(25 \mathrm{~b})$,

$$
\begin{gathered}
\log Y_{i t}=\hat{\alpha}_{L, j} \log L_{i t}+\hat{\alpha}_{M, j} \log M_{i t}+\hat{\alpha}_{K, j} \log K_{i t}+\log T F P_{i t} \\
\log T F P_{i t}=\hat{\alpha}_{I C, j} \log I C_{i t}+\hat{\alpha}_{C, j} \log C_{i t}+\hat{\alpha}_{T F P}+\hat{u}_{i t} .
\end{gathered}
$$

If the constancy of the input-output elasticities in (21a) is not satisfied we could estimate a Translog production function, in the first step, and use those residual as the estimates of $\log$ TFP in the second step, equation (25b).

However, assumption 4.2 is almost never satisfied since the inputs are correlated with the IC variables and least squares estimators of (25a) are inconsistent and biased. Therefore, in the empirical section, we suggest using the following alternative option 4.2.

\section{Option 4.2: One-step regression approach}

If $\log P_{i t}$ is correlated with the inputs, $\mathrm{L}_{\mathrm{it}}, \mathrm{M}_{\mathrm{it}}$ and $\mathrm{K}_{\mathrm{it}}$, we can estimate the system (21a) and (21b) in a single step, as in equation (26), under assumptions 4.1, 4.3 and 4.4,

\footnotetext{
${ }^{12}$ Notice that the regressions in step one (25a) and step two (25b) should have a constant term and therefore the constant term is not identified. One possible solution is to include a constant in the first step regression and then add back the estimated coefficient to the residuals before you create $\log T F P_{i t}$. Therefore, the constant term should always be part of the TFP for consistency with the growth accounting measures (Solow residual) of TFP.
} 


$$
\begin{gathered}
\log Y_{i t}=\alpha_{L, j} \log L_{i t}+\alpha_{M, j} \log M_{i t}+\alpha_{K, j} \log K_{i t}+ \\
+\alpha_{I C, j} \log I C_{i t}+\alpha_{C, j} \log C_{i t}+\alpha_{P}+u_{i t} .
\end{gathered}
$$

Now, under assumption 4.4 on (26), and other regularity conditions, we can get consistent and unbiased estimators of the impact of IC variables on P by least squares. If assumption 4.4 is not satisfied because, for example, the IC variables are endogenous, we should use instrumental variables or other consistent estimation procedures of the parameters of equation (26). In the empirical section we discuss how to solve this problem using regional industry averages by country for the IC variables and, if needed, we could use the available information on IC perceptions given by the firms (control function approach), as will become clear later.

If the assumption 4.1 about the constancy of the input-output elasticity of $\mathrm{L}, \mathrm{M}$ and $\mathrm{K}$ is not satisfied, we could estimate by regression techniques a Translog specification for the production function, estimating equation (27) instead of (26),

$$
\begin{aligned}
& \log Y_{i t}=\alpha_{L, j} \log L_{i t}+\alpha_{M, j} \log M_{i t}+\alpha_{K, j} \log K_{i t}+ \\
& \quad+\frac{1}{2} \alpha_{L L, j}\left(\log L_{i t}\right)^{2}+\frac{1}{2} \alpha_{M M, j}\left(\log M_{i t}\right)^{2}+\frac{1}{2} \alpha_{K K, j}\left(\log K_{i t}\right)^{2}+ \\
& +\alpha_{L M, j}\left(\log L_{i t}\right)\left(\log M_{i t}\right)+\alpha_{L K, j}\left(\log L_{i t}\right)\left(\log K_{i t}\right)+\alpha_{M K, j}\left(\log M_{i t}\right)\left(\log K_{i t}\right)+ \\
& +\alpha_{I C, j} \log I C_{i t}+\alpha_{C, j} \log C_{i t}+\alpha_{P}+u_{i t} .
\end{aligned}
$$

The Translog specification allows us also to test if the technology is Cobb-Douglas. With both parametric specifications of the production function $\mathrm{F}(\mathrm{L}, \mathrm{M}, \mathrm{K})$, we could test the constant returns to scale (CRS) condition (assumption 4.5) usually used in growth accounting measures of TFP. (See options 3.3 and 4.3.) When we are not willing to make assumption 4.1, about the constancy of the input output elasticities, we can use the following growth accounting procedures to get a measure of $\log \mathrm{P}_{\text {it }}$ indicated in option 4.3. 


\section{Option 4.3: Nonparametric procedure based on cost-shares (Solow's residual in levels)}

If one believes that the more reliable measures of productivity are based on rates of growth, say $\Delta \log P_{j, i}$ based on equation (13), but on the other hand we want to do the productivity analysis in levels (or $\operatorname{logs}$ ), we can generate $\log P_{j, i}$ once we have a consistent cross-section estimate of the initial value, (say $\log P_{i 0}$ ). To generate the other values of $\log P_{j, i}$ we could use the recursive formula ${ }^{13} \log P_{i t}=\log P_{i, t-1}+\Delta \log P_{i t}$ for $\mathrm{t}=1,2, \ldots$, T. However, we will not pursue this procedure since it does not fit the characteristics of our data set, we have IC observations for only one year. Furthermore, our data set has many missing observations during the first of the two years. Therefore we will lose many observations if we took first differences.

For our purposes we can, under assumptions 4.5 and 4.6, generate productivity $(\mathrm{P}=\mathrm{TFP})$ while allowing the input elasticities $\alpha_{j, i, t}$ to be nonconstant. Say that $\alpha_{j, i, t}$ is equal to the cost share $\left(s_{j, i t}\right)$ for $j=L_{i t}, M_{i t}$ and $K_{i t}$, which are observable, see option 3.3 equations (12a)-(12c) for more details.

$$
\log T F P_{i t}=\log Y_{i t}-S_{L, i t} \log L_{i t}-s_{M, i t} \log M_{i t}-S_{K, i t} \log K_{i t} .
$$

Since now we do not have to approximate the continuous rate of growth (dlogTFP) by a discrete measure $(\Delta \log \mathrm{P})$, in equation (28) we can either use the cost shares $s_{j, i, t}$ of each year $\mathrm{t}$, or the average of the last two years $\bar{s}_{j, i, t}$ for consistency with option 3.3 and equation (13):

\footnotetext{
${ }^{13}$ In fact Solow(1967) considered that $P_{i 0}=1$ or that $\log \mathrm{P}_{\mathrm{i} 0}$ is 0 . This is not a good initial estimate of $\log \mathrm{P}$ and it has an important impact since $\log \mathrm{P}$ is an integrated process of $\Delta \log \mathrm{P}$. If $\Delta \log \mathrm{P}$ is $\mathrm{I}(0)$ then $\log \mathrm{P}$ is an $\mathrm{I}(1)$ process and the effect of $\log \mathrm{P}_{0}$ is permanent and not transitory. See Escribano and Pena (2004) for a further analysis of the initial conditions effect on the correlation between alternative productivity measures.
} 


\section{Econometric Methodologies for Investment Climate Assessments on Productivity}

$$
\log T F P_{i t}=\log Y_{i t}-\bar{s}_{L, i t} \log L_{i t}-\bar{s}_{M, i t} \log M_{i t}-\bar{s}_{K, i t} \log K_{i t}
$$

where $\bar{s}_{j, i, t}$ is the average cost shares from the last two years given by $\bar{s}_{j, i, t}=\frac{1}{2}\left(s_{j, i, t}+s_{j, i, t-1}\right)$ for $\mathrm{j}=\mathrm{L}_{\mathrm{it}}, \mathrm{M}_{\mathrm{it}}$ and $\mathrm{K}_{\mathrm{it}}$.

Alternatively, under assumptions 4.5, 4.6 and 4.7 we can measure $\log \mathrm{P}=\log$ TFP knowing that the input elasticities $\bar{\alpha}_{j, i, t} \alpha_{j, i, t}$ are equal to the income shares $\left(\mathrm{ys}_{\mathrm{j}, \mathrm{it}}\right)$ where $\mathrm{j}=\mathrm{L}_{\mathrm{it}}, \mathrm{M}_{\mathrm{it}}$ and $\mathrm{K}_{\mathrm{it}}$, which are observable. The original Solow residuals (SR) under CRS are the residuals from the output equation not explained by the inputs (L,M,K), using equation (30) with $y s_{K, i t}=1-y s_{L, i t}-y s_{M, i t}:$

$$
\log T F P_{i t}=\log Y_{i t}-y s_{L, i t} \log L_{i t}-y s_{M, i t} \log M_{i t}-y s_{K, i t} \log K_{i t} .
$$

Similarly, as we did with equation (29) we could use the average income share of the last two years, for consistency with option 3.4 .

$$
\log T F P_{i t}=\log Y_{i t}-y \bar{s}_{L, i t} \log L_{i t}-y \bar{s}_{M, i t} \log M_{i t}-y \bar{s}_{K, i t} \log K_{i t}
$$

where the average income shares from the last two years are given by $y \bar{s}_{j, i, t}=\frac{1}{2}\left(y s_{j, i, t}+y s_{j, i, t-1}\right)$ for $j=L_{i t}, M_{i t}$ and $K_{i t}$.

The advantage of option 4.3, based on the Solow residuals, is that it does not require the inputs $(\mathrm{L}, \mathrm{M}, \mathrm{K})$ to be exogenous or the inputs elasticities to be constant. The disadvantage is that it requires having constant returns to scale (CRS) and competitive input markets.

In summary, measuring productivity in levels (logs) is more restrictive than measuring productivity growth (requires specific functional forms of the production function, etc.) but it is less demanding in terms of data quality requirements (allows to have an unbalanced panel 
with short time dimension, some measurement errors, constant values of IC variables, etc). Therefore, we will concentrate on measures of productivity and not of productivity growth.

In the following section we describe the econometric methodology suggested for evaluating the impact of IC variables on several productivity measures in levels (logs) and we introduce the Olley and Pakes (1996) decomposition for studying the allocation efficiency of the firms by sector in each year.

\section{Proposed Econometric Methodology to Estimate the Productivity Impact of IC Variables in Guatemala, Honduras and Nicaragua}

We have seen in sections 3 and 4 , that there is no single measure of productivity $\left(\mathrm{P}_{\mathrm{it}}\right)$ and that in general they do not correspond to total factor productivity (TFP ${ }_{i t}$ ). Any empirical evaluation on the impact of IC variables is contingent on the way we measure productivity. Therefore, to get reliable results for policy analysis we suggest using econometric procedures that give consistent and robust conclusions and that do not depend on the particular measure of productivity used. This is the approach we follow in the rest of the paper.

For this purpose, we use the 10 productivity measures (see section 6) that best fit with the characteristics of our data set. We follow the procedures mentioned in options 4.2 and 4.3, under alternative levels of aggregation (country, industry, young and old firms, etc.) and we consider two parametric production functions, the Cobb-Douglas and the Translog. 


\section{Description of the Data}

The data base is a short unbalanced panel of three countries: Guatemala, Honduras and Nicaragua. We have temporal observations $(\mathrm{T}=2)$ for 2001 and 2002 for most variables. However, for the IC variables, which are listed in Tables A1 to A3 of the appendix, we have observations only for the year 2002.

This raises the first question: should we only use cross-section data (say only for 2002) or, should we also use the data for 2001, even if we do not have information on the IC variables for that year? To address this issue we assume that, unless there is a structural break, the IC variables do not change much from one year to the next. In fact, what can change from one year to the next is the reaction of the firm facing a certain investment climate, but that depends on the firm's perceptions of the impact of IC variables and on the time required for firm to implement the corresponding adjustments. Under these hypotheses, we could allow the coefficients of certain IC variables to change from one year to the next while maintaining the values of the IC variables constant during 2001 and 2002. In the empirical application we maintain constant the IC coefficients and add some temporal dummies affecting the constant term of the productivity equations in each year.

We are interested in using as many observations as possible to benefit from the law of large numbers. Hence, we suggest pooling the data from the three countries, and later analyze their differences and similarities. This is important because our observations are very unevenly distributed through time and across firms, precluding us from doing separate country analyses of each industry or sector. (See Table B1 of the appendix.) For example, if we conduct an industry analysis country by country, we will have a textile sector in Honduras with only nine observations, while if we pool the observations from the three countries we get at least 38 observations in that sector, giving more reliable statistical results. 
In 2001, after pooling the observations from the three countries, we only have 441 observations while for 2002 we have 1,020 observations. Therefore, if we measure productivity using rates of growth (see section 3 ) we will have at most 441 firms, which is a very small sample size to study differences by industry and by country. However, if we do the analysis in levels or logs (see section 4) we get 1,461 observations in total which will help us get more reliable statistical results. From Table B1 of the appendix it is clear that the three countries have similar number of observations for the two-year period: Guatemala has 468 firms, Honduras 472 and Nicaragua 521.

\section{Cobb-Douglas Extended Production Function (one-step estimation)}

Starting with the Cobb-Douglas, let us assume that the parameters are constant within each industry $\mathrm{j}$ :

$$
\begin{gathered}
\log Y_{i t}=\alpha_{L, j} \log L_{i t}+\alpha_{M, j} \log M_{i t}+\alpha_{K, j} \log K_{i t}+\log P_{i t} \\
\log P_{i t}=\alpha_{I C} \log I C_{i t}+\alpha_{C} \log C_{i t}+\alpha_{P}+u_{i t}
\end{gathered}
$$

where the inputs (L,M and $\mathrm{K}$ ) are correlated with productivity through the investment climate (IC) variables and maybe also through some plant control (C) characteristics.

We suggest a one-step procedure to estimate equations (32a) and (32b) that addresses the simultaneous equation bias, generated if we estimate first equation (32a) to get a measure of productivity. Secondly, we use this productivity measure to evaluate the impact of IC variables. To solve the endogeneity problem of some of the inputs, Olley and Pakes (1996), Levinsohn and Petrin (2003) and Akerberg and Caves (2003) proposed a structural approach. Dollar et al. (2004) following Levinsohn and Petrin (2003), study IC effects on TFP using a two-step estimation procedure. However, this approach does not fit well with the characteristics of our data base, since it requires to have a single unobserved source of simultaneity and a detailed sequential timing of the inputs decision which is too restrictive for 
annual data. One could argue that he timing of the inputs decision structure assumed in Olley and Pakes (1996) and Levinsohn and Petrin (2003), etc. is reasonable if we have daily, weekly, monthly or even quarterly observations, but it is unrealistic with annual data. We have annual data on several usually unobserved IC variables. Therefore, we must a priori consider the possibility that the three inputs (L, M and $\mathrm{K}$ ) are endogenous (correlated with some of the IC variables) and therefore correlated with productivity: $\mathrm{E}\left(\mathrm{L}_{\mathrm{it}}, \mathrm{P}_{\mathrm{it}-\mathrm{j}}\right) \neq 0, \mathrm{E}\left(\mathrm{M}_{\mathrm{it}}, \mathrm{P}_{\mathrm{it}-}\right.$ $\mathrm{j}) \neq 0$ and $\mathrm{E}\left(\mathrm{K}_{\mathrm{it}}, \mathrm{P}_{\mathrm{it}-\mathrm{j}}\right) \neq 0$, for any $\mathrm{j} \geq 0$ and any $\mathrm{j} \leq 0$.

To address the endogeneity problem of the inputs, we adopt the following structural simultaneous equation approach. Let the production function to be given by the following equation $^{14}$ :

$$
\log Y_{i t}=\alpha_{L, j} \log L_{i t}+\alpha_{M, j} \log M_{i t}+\alpha_{K, j} \log K_{i t}+\log P_{i t}
$$

Consider that the demand for each of the inputs (L, M and $\mathrm{K}$ ) is given by their corresponding competitive input price $\left(\mathrm{w}_{\mathrm{it}}\right)$, by $\mathrm{q}_{\mathrm{j}}$ investment climate (IC) variables, $\sum_{j=1}^{q_{j}} \gamma_{j, i} \log I C_{j i t}$, and by qinput firm characteristics given by $\sum_{r=1}^{q_{\text {input }}} \alpha_{C, i} \log C_{r, i t}$. That is,

$$
\text { input }_{i t}=\sum_{r=1}^{q_{\text {input }}} \gamma_{I C, r j} \log I C_{r, i t}+\sum_{r=1}^{q_{\text {input }}} \gamma_{C, r j} \log C_{r, i t}+\gamma_{w, j} \log w_{i t}+v_{i t}
$$

where the dependent variable represents each of the inputs demand ${ }^{15}$, input $t_{i t}=\mathrm{L}_{\mathrm{it}}, \mathrm{M}_{\mathrm{it}}$ and $\mathrm{K}_{\mathrm{it}}$.

\footnotetext{
${ }^{14}$ We could have as well considered the Translog production function specification.

${ }^{15}$ Notice that we are allowing the inputs' demand to be stochastic, while in Olley and Pakes (1996) these are deterministic.
} 
Consider that productivity $\mathrm{P}_{\mathrm{it}}$ is affected by $\mathrm{q}_{\mathrm{C}}$ of the firm's characteristics $\left(\mathrm{C}_{\mathrm{it}}\right)$ and by $\left(\mathrm{q}_{\mathrm{IC}}\right)$ of the usually unobserved characteristics which we consider to be related to the investment climate $\left(\mathrm{IC}_{\mathrm{it}}\right)$ variables affecting each firm,

$$
\log P_{i t}=\sum_{r=1}^{q_{I C}} \alpha_{I C, r j} \log I C_{r, i t}+\sum_{r=1}^{q_{C}} \alpha_{C, r j} \log C_{r, i t}+\alpha_{P}+u_{i t} .
$$

Notice that equation (33c) is a generalization of (32b) in the sense that we are allowing for multiple IC and $\mathrm{C}$ variables in the productivity equation. This is important now since we are assuming that Equation (33c) includes all the IC and C variables from (33b) and many other IC and $\mathrm{C}$ variables that affect productivity but not the inputs of (33b).

Assuming that the errors $v_{\mathrm{it}}$ and $\mathrm{u}_{\mathrm{it}}$ are mutually independent and uncorrelated with the explanatory variables in (33b) and (33c) and that all the correlation between inputs (L, M and $\mathrm{K})$ and productivity comes from the IC variables and the C characteristic of (33b), and not from the competitive input prices (w). After controlling for IC and C variables we can jointly estimate the parameters of the input-output elasticities from the following extended production function (34),

$$
\log Y_{i t}=\alpha_{L, j} \log L_{i t}+\alpha_{M, j} \log M_{i t}+\alpha_{K, j} \log K_{i t}+\sum_{r=1}^{q_{I C}} \alpha_{I C, r j} \log I C_{r, i t}+\sum_{r=1}^{q_{C}} \alpha_{C, r j} \log C_{r, i t}+\alpha_{P}+u_{i t} .
$$

\section{Translog Extended Production Function (one-step estimation)}

Using similar arguments, we estimate a Translog specification of the extended production function from 


$$
\begin{aligned}
& \log Y_{i t}=\alpha_{L, j} \log L_{i t}+\alpha_{M, j} \log M_{i t}+\alpha_{K, j} \log K_{i t}+ \\
& \quad+\frac{1}{2} \alpha_{L L, j}\left(\log L_{i t}\right)^{2}+\frac{1}{2} \alpha_{M M, j}\left(\log M_{i t}\right)^{2}+\frac{1}{2} \alpha_{K K, j}\left(\log K_{i t}\right)^{2}+ \\
& +\alpha_{L M, j}\left(\log L_{i t}\right)\left(\log M_{i t}\right)+\alpha_{L K, j}\left(\log L_{i t}\right)\left(\log K_{i t}\right)+\alpha_{M K, j}\left(\log M_{i t}\right)\left(\log K_{i t}\right)+ \\
& +\sum_{r=1}^{q_{I C}} \alpha_{I C} \log I C_{r, i t}+\sum_{r=1}^{q_{C}} \alpha_{C} \log C_{r, i t}+\alpha_{P}+u_{i t} .
\end{aligned}
$$

The Translog specification (35) allows us to find out whether the technology is CobbDouglas, by testing if the extended production function (35) can be reduced to (34) in which all the nonlinear terms of the production function have been eliminated. Furthermore, with both (34) and (35) parametric specifications of the production function $\mathrm{F}(\mathrm{L}, \mathrm{M}, \mathrm{K})$, we may test the assumption of constant returns to scale ${ }^{16}$ (CRS).

\section{Solow Residuals in Levels (two step estimation)}

A different measure of productivity is obtained by using the nonparametric procedure discussed in option 4.3. The advantage of this alternative procedure is that we do not have to face the previous simultaneous equation problem (endogeneity of inputs) since we are not estimating the input-elasticities by regression techniques but from the cost shares based on observable variables at the firm level and for each year. Therefore, this nonparametric procedure allows us to analyze the productivity $\left(\mathrm{P}_{\mathrm{it}}\right)$ effects of IC variables in two steps.

In the first step we generate $\log P_{i t}$ (Solow Residuals in levels) from equation (36a) where $s_{j, i, t}$ is the cost share of firm i during year $t$, or the average of the last two years $\left(\bar{s}_{j, i, t}\right)$ as explained in equation (29):

\footnotetext{
${ }^{16}$ For example, if the coefficients of the inputs (L,M and $\mathrm{K}$ ) in the Cobb-Douglas specification of the production function add up to one. Similar but more complicated coefficient restrictions apply for a CRS Translog production functions, see Table C.3.3 for an application.
} 


$$
\log Y_{i t}=\bar{s}_{L, i t} \log L_{i t}+\bar{s}_{M, i t} \log M_{i t}+\bar{s}_{K, i t} \log K_{i t}+\log P_{i t}
$$

where $\bar{s}_{j, i, t}$ is given by $\bar{s}_{j, i, t}=\frac{1}{2}\left(s_{j, i, t}+s_{j, i, t-1}\right)$ for $\mathrm{j}=\mathrm{L}_{\mathrm{it}}, \mathrm{M}_{\mathrm{it}}$ and $\mathrm{K}_{\mathrm{it}}$.

In the second step, we estimate the IC elasticities and semi-elasticities through regression techniques from equation

$$
\log P_{i t}=\sum_{r=1}^{q_{I C}} \alpha_{I C, r} \log I C_{r, i t}+\sum_{r=1}^{q_{C}} \alpha_{C, r} \log C_{r, i t}+\alpha_{P}+u_{i t}
$$

Once we have estimated those elasticities by pooling the data from the three countries (Guatemala, Honduras and Nicaragua) we want to evaluate the productivity contribution of each IC variable country by country.

\section{Evaluation of the Average Productivity Contribution of each IC Variable}

This equation, estimated by least squares with a constant term, implies that the mean of the residuals is zero and therefore that we can evaluate (36b) at the mean values without an error term:

$\log \bar{P}_{i t}=\sum_{r=1}^{q_{I C}} \hat{\alpha}_{I C, r} \log \overline{I C}_{i t}+\sum_{r=1}^{q_{C}} \hat{\alpha}_{C, r} \log \bar{C}_{i t}+\hat{\alpha}_{P}$. Dividing the whole expression by the dependent variable and multiplying by 100 , we get

$100=\sum_{r=1}^{q_{I C}}\left(\frac{\hat{\alpha}_{I C, r} \log \overline{I C}_{i t}}{\log \bar{P}_{i t}} 100\right)+\sum_{r=1}^{q_{C}}\left(\frac{\hat{\alpha}_{C, r} \log \bar{C}_{i t}}{\log \bar{P}_{i t}} 100\right)+\left(\frac{\hat{\alpha}_{P}}{\log \bar{P}_{i t}} 100\right)$, which represents the sum of the percentage productivity gains and losses from all the explanatory variables of the regression, relative to the average log productivity. In particular, the contribution of each IC 
variable to average $(\log )$ productivity is given by the term $\left(\frac{\hat{\alpha}_{I C, r} \log \overline{I C}_{i t}}{\log \bar{P}_{i t}} 100\right)$. Applying this analysis country by country ${ }^{17}$ we obtain the results of Tables E. 1 to E.3 of the appendix that will be discussed later on.

In the empirical section, we also consider the possibility of having nonlinear impacts of IC variables on productivity in equations (34), (35) and (36b) by including linear terms as well as the square and cubic terms of the $\log \mathrm{IC}$ and $\log \mathrm{C}$ variables that appear in those equations.

\section{Estimation of Extended Production Functions}

Controlling for the largest set of IC variables and firm characteristics, as in (34), we can get under standard regularity conditions, consistent and unbiased least squares estimators of the parameters of the production function and of the productivity equation. That is, we can run OLS from a one-step regression ${ }^{18}$ based on the extended production function (34). In the empirical section we allow the errors $\left(\mathrm{u}_{\mathrm{it}}\right)$ from (34) and (35) to be heteroskedastic and therefore we will be using pooling OLS with robust standard errors and also random effects (RE) estimators.

We initially tried to compare the results from the three most common panel data estimators: pooling OLS, random effects and fixed effects. However, we discarded fixed effects estimators for three reasons: First, because not many important unobserved factors are left, after adding many of the usually unobserved ${ }^{19}$ variables in previous regression studies. Second, because we have information about 2001 and 2002 and therefore running fixed effects is equivalent to running OLS in a regression with the variables in first differences.

\footnotetext{
${ }^{17}$ Notice that the mean of the residuals of each country might not now be equal to zero, although it will be a small term.

${ }^{18}$ Alternatively, we could have used an equivalent two-step control function approach procedure where we first estimate by OLS a regression of each of the inputs on all the IC and C variables (partialling out) and then include the residuals of each estimated input equation, instead of the observed inputs, in the production function (32a).

${ }^{19}$ The ICA surveys by the World Bank provide much information about individual firms that is usually not observed by the econometrician.
} 


\section{Econometric Methodologies for Investment Climate Assessments on Productivity}

However, we will lose a great deal of information by doing the analysis in first differences since the sample size is reduced from 1,461 observations to 441, as mentioned above. Third, most of the plant-level variables might be subject to measurement errors and by taking first differences on those variables we enhance the undesired estimation impact of those measurement errors. Therefore, for those reasons, we do not use the fixed effect estimators and we estimate the contribution of IC variables to productivity in levels (logs), and not to productivity growth, by pooling OLS with robust standard errors and by fixed effects.

\section{Endogeneity of the IC Variables}

Another econometric problem that we have to face in estimating (34), (35) and (36b) is the possible endogeneity of IC variables and some $\mathrm{C}$ variables. The traditional instrumental variable (IV) approach is difficult to implement in this context, given that we only have IC variables for one year and therefore we cannot use the natural instruments like those provided by their on lags, etc. As alternative estimation procedures to correct for the endogeneity of the IC variables, we apply the following two complementary procedures:

First, we use the region-industry average of the plant level investment climate variables $(\overline{I C})$ instead of the crude IC variables, to reduces the degree of endogeneity of the IC variables. We have, in total, 13 regions for the three countries and nine industries for each country. Furthermore, taking region and industry averages also helped us to mitigate the effect of missing IC observations for some firms.

Second, we follow a complementary approach based on the information provided by perception variables ${ }^{20}$ which are related to the IC information. The perception variables (PE) incorporate firms' answers to several questions related to difficulties they face for operation and growth, ranked from "no problem" through "minor", "moderate", "major" and "very

\footnotetext{
${ }^{20} \mathrm{We}$ could have considered the use of perception variables as instruments for IC variables. However, those perception variables are endogenous and not highly correlated with the IC variables (weak instruments for IC variables in the best case). Therefore, we prefer to use perception variables for partialling out the endogenous effects of IC variables.
} 
severe" problems. (See Table A4 of the appendix.) We assume that in the survey the IC variables are endogenous because when filling the quantitative answers to the IC questions, firms are influenced by their own perception on the productivity of the firm. In formal terms, we can say that

$$
\begin{aligned}
& \log I C_{i t}=\sum_{r=1}^{q_{P E_{i}}} \beta_{P E, i r} \log P E_{r, i t}+\sum_{r=1}^{q_{I C, P E_{i}}} \beta_{C, i r} \log C_{r, i t}+\zeta_{i t} \\
& \log P_{i t}=\sum_{r=1}^{q_{I C}} \alpha_{I C, r} \log I C_{r, i t}+\sum_{r=1}^{q_{C}} \alpha_{C, r} \log C_{r, i t}+\alpha_{P}+\alpha_{P i}+v_{i t} .
\end{aligned}
$$

where the error $u_{i t}$ in (36b) is related to the error in (37b) by the following expression $u_{i t}=\alpha_{P i}+v_{i t}$. That is, $\mathrm{u}_{\mathrm{it}}$ is correlated with the $\mathrm{IC}$ variables, $\mathrm{E}\left(\mathrm{IC}_{\mathrm{it}}, \mathrm{u}_{\mathrm{it}}\right)=\mathrm{E}\left(\mathrm{IC}_{\mathrm{it}}, \alpha_{P i}\right) \neq 0$ because the perception variables (PE) of each firm are correlated with the unobserved fixed effect term $\left(\alpha_{P i}\right)$. If the random error terms in (37a) and (37b) are uncorrelated, $\mathrm{E}\left(\zeta_{\mathrm{it}}, v_{\mathrm{it}}\right)=$ 0 , we can solve the endogeneity problem by controlling ${ }^{21}$ for the perception variables (PE) of (37a) forming the new extended production function equation:

$$
\log P_{i t}=\sum_{r=1}^{q_{I C}} \alpha_{I C, r} \log I C_{r, i t}+\sum_{r=1}^{q_{C}} \alpha_{C, r} \log C_{r, i t}+\sum_{r=1}^{q_{P E_{i}}} \alpha_{P E, r} \log P E_{r, i t}+\alpha_{P}+\eta_{i t}
$$

Since, after controlling for PE, the new error term from (38) is now uncorrelated with the IC variables, pooling (OLS) in (38) provides consistent and unbiased elasticity parameter estimates. Similar procedures could be applied to equations (34) and (35) by simply adding the necessary PE variables.

\section{Strategy for IC Variables’ Selection}

\footnotetext{
${ }^{21}$ This is equivalent to the linear version of the control function approach discussed in Blundell and Powel (2003).
} 
The econometric methodology applied for the selection of the variables (IC, C and PE) goes from the general to the specific. The omitted variables problem that we encounter, starting from a too simple model generates biased and inconsistent parameter estimates. Therefore we should not estimate a simple model and add one by one IC variables and checking if they are individually significant. On the contrary, adding irrelevant variables (meaning starting from a very general model with some variables that are irrelevant) gives unbiased and consistent, but inefficient, estimates. Therefore, we should start from a general model, such as equations (35) and (36), with all the variables of Tables A1 to A3 included at once, and reduce this general model to a simple one with relevant (significant) variables ${ }^{22}$. Note that the final estimated model is efficiently estimated once we have deleted insignificant or irrelevant variables.

In the reduction process we should not delete all insignificant variables at once. Due to multicolinearity, if we drop one variable that is highly correlated with others, some of the insignificant variables might become significant. An informative statistic for this purpose is the variation of the $\mathrm{R}^{2}$ of the regression (or the standard error of the regression). The $\mathrm{R}^{2}$ of the simplified model (with only significant or relevant variables) should be smaller but close to the $\mathrm{R}^{2}$ of the most general model. We applied this iterative procedure, eliminating the less significant variables one by one, leaving, for interpretive purposes at least one IC variable from each broad category (infrastructure, bureaucracy/corruption, crime, technology and quality, human capital, corporate governance, etc.). The estimated explanatory variables of the regression models of Tables $\mathrm{C} 2$ to $\mathrm{C} 7$ of the appendix, were selected in this way. We include in those tables the set of IC variables that were significant in at least one of the specifications or estimating procedures considered (pooling OLS or random effects). These regression results are consistent (with equal signs and a reasonable range of parameter values) and allow us to interpret the estimated coefficients and their signs with confidence.

\footnotetext{
${ }^{22}$ Sometimes, in the final regression model, we leave IC variables that are not individually significant but are relevant for the model (jointly significant, affect the significance of other variables, etc.). When this happens it could be due to the presence of multicolinearity among some of the explanatory variables.
} 


\section{Allocative Efficiency: The Olley and Pakes Decomposition}

We now want to discuss the Olley and Pakes (1996) decomposition of productivity because it is useful to evaluate the allocation efficiency of the firms. These decomposition tell us if the most productive firms are the ones with larger market share or not.

Let $P_{j t}=\sum_{i=1}^{N_{j t}} s_{i t} P_{j, i t}$ be the aggregate productivity of industry $j$ at time $t$ obtained as the weighted average of $i$-plant-level productivity in industry $j$ at year $t$, where $N_{j t}$ is the number of firms in industry $\mathrm{j}$ and $\mathrm{j}=1, \ldots, 9$ industries. The weights $\left(\mathrm{s}_{\mathrm{it}}\right)$ indicate the share of the sales of firm $\mathrm{i}$ in year $\mathrm{t}$ over the total sales of industry $\mathrm{j}$ of that year. Let $\bar{P}_{j t}=\frac{1}{T} \sum_{i=1}^{N_{j t}} p_{j, i t}$ be the sample average productivity of the firms of industry $\mathrm{j}$ in year $\mathrm{t}$. Then the annual aggregate productivity of industry $\mathrm{j}$ can be decomposed as:

$$
P_{j t}=\sum_{i=1}^{N_{j t}} s_{j, i t} P_{j, i t}=\sum_{i=1}^{N_{j t}}\left[\bar{S}_{j, t}+\tilde{S}_{j, i t}\right]\left[\bar{P}_{j, t}+\tilde{P}_{j, i t}\right]
$$

where $\tilde{s}_{j, i t}=\left(s_{j, i t}-\bar{s}_{j, i}\right)$ and $\tilde{P}_{j, i t}=\left(P_{j, i t}-\bar{P}_{j, t}\right)$ are in deviations to the mean. Simplifying equation (39) we get the Olley and Pakes (1996) decomposition:

$$
P_{j t}=\bar{P}_{j t}+\sum_{i=1}^{N_{j t}} \tilde{s}_{j, i t} \tilde{P}_{j, i t}
$$

The first term $\left(\bar{P}_{j t}\right)$ is the average productivity of industry $\mathrm{j}$ in year $\mathrm{t}$ and the second term $\left(\sum_{i=1}^{N_{j t}} \tilde{s}_{j, i t} \tilde{P}_{j, i t}\right)=\operatorname{cov}\left(s_{j, i t}, P_{j, i t}\right) \quad$ "measures" the covariance between output shares and productivity, $\operatorname{cov}\left(\mathrm{s}_{\mathrm{j}, \mathrm{it}}, \mathrm{P}_{\mathrm{j}, \mathrm{it}}\right)$, of the firms that belong to industry $\mathrm{j}$. If the covariance is positive, 
then the larger it is, the higher will be the share of sales that goes to more productive firms, allocation efficiency is increased and industry productivity is enhanced. If the covariance is negative, we can interpret that as an allocation inefficiency since the more negative the covariance is, the higher will be the share of output that goes to less productive firms, reducing industry productivity.

In terms of differences, we have that $\Delta P_{j t}=\Delta \bar{P}_{j t}+\Delta \operatorname{cov}\left(s_{j, i t}, P_{j, i t}\right)$. This decomposition tells us that if there is an increase in the productivity of industry $\mathrm{j}$, it must be due to an increase in average productivity of the industry or to an increase in the reallocation of production $\left(\mathrm{s}_{\mathrm{it}}\right)$ toward more productive firms (higher $\mathrm{P}_{\mathrm{it}}$ ).

In section 6 we produce an empirical application at the different aggregation levels of industry and country, and in section 7 we also distinguish between small and large firms and between young and old ones.

\section{Step-by-Step Implementation of this Productivity Methodology}

For policy implications we require the estimated elasticities of IC variables to be robust: 1) among different functional forms of the production functions; 2) among different consistent estimation procedures; 3) among different productivity measures; and 4) among different levels of aggregation (industry, country, pooling countries, etc).

In all the panel data regressions estimated with different productivity measures, 11 dummy variables $\left(D_{\mathrm{rt}}, \mathrm{r}=1,2, \ldots, 11\right)$ and a constant term were included. To control for a constant industry effect of the nine industries (apparel, beverages, chemicals/rubber, food/tobacco, furniture/wood, leather/shoes, nonmetallic minerals, textiles, metal), we include only eight dummy variables, leaving out apparel to avoid having perfect multicolinearity with the constant term. Similarly, we add only one yearly dummy variable leaving out the 
corresponding dummy for the year 2001. To control for a constant country effect we include two dummies, one for Honduras and the other for Nicaragua, with Guatemala omitted.

As mentioned in section 5, to reduce the simultaneous equation bias and the risk of getting reverse causality problems if the $\mathrm{IC}_{\mathrm{it}}$ variables are endogenous, we use their region-industry average $\left(\overline{I C}_{\mathrm{jt}}\right)$. The coefficients of investment climate $\left(\overline{I C}_{\mathrm{it}}\right)$ variables and other plantspecific control $\left(\mathrm{C}_{\mathrm{it}}\right)$ variables are maintained constant for the three countries while we allow the production function elasticities, and therefore the productivity measures, to change for each functional form (Cobb-Douglas and Translog) and for two different aggregation levels (industry and countries). Restricted estimation (equal input elasticities among industries for the three countries) and unrestricted estimation (different coefficients for each industry), are the two levels of aggregation considered in the input elasticities of each production function. Moreover, we consider two different estimators (pooling OLS and random effects). The following Table summarize the productivity measures and the corresponding IC elasticities:

\begin{tabular}{|c|c|c|c|c|}
\hline \multicolumn{5}{|c|}{$\begin{array}{l}\text { Summary of Productivity Measures and } \\
\text { Estimated Investment Climate (IC) Elasticities }\end{array}$} \\
\hline 1. Solow's Residual & $\begin{array}{l}\text { Two Step } \\
\text { Estimation }\end{array}$ & $\begin{array}{l}\text { 1.1 Restricted Coef } \\
\text { 1.2 Unrestricted Coef }\end{array}$ & $\begin{array}{l}\text { 1.1.a OLS } \\
\text { 1.1.b RE } \\
\text { 1.2.a OLS } \\
\text { 1.2.b RE }\end{array}$ & $\begin{array}{l}2\left(P_{\text {it }}\right) \text { measures } \\
4 \text { (IC) elasticities }\end{array}$ \\
\hline 2. Cobb-Douglas & $\begin{array}{l}\text { Single Step } \\
\text { Estimation }\end{array}$ & $\begin{array}{l}\text { 2.1 Restricted Coef } \\
\text { 2.2 Unrestricted Coef }\end{array}$ & $\begin{array}{l}\text { 2.1.a OLS } \\
\text { 2.1.b RE } \\
\text { 2.2.a OLS } \\
\text { 2.2.b RE }\end{array}$ & $\begin{array}{l}4\left(P_{\text {it }}\right) \text { measures } \\
4(\mathrm{IC}) \text { elasticities }\end{array}$ \\
\hline 3. Translog & $\begin{array}{l}\text { Single Step } \\
\text { Estimation }\end{array}$ & 3.1 Restricted Coef & $\begin{array}{l}\text { 3.1.a OLS } \\
\text { 3.1.b RE } \\
\text { 3.2.a OLS }\end{array}$ & $\begin{array}{l}4\left(P_{i t}\right) \text { measures } \\
4(\mathrm{IC}) \text { elasticities }\end{array}$ \\
\hline
\end{tabular}




\section{2.b RE}

$10\left(\mathbf{P}_{\mathrm{it}}\right)$ measures

Total

12 (IC) elasticities

Restricted Coef.= Equal input-output elasticities in all industries of the three countries

Unrestricted Coef. = Different input output elasticities by industry of the three countries

OLS = Pooling Ordinary Least Squares estimation (with robust standard errors)

$R E=$ Random Effects estimation

Thus we obtain 10 different productivity measures $\left(\mathrm{P}_{\mathrm{it}}\right)$ and we evaluate the impact of IC variables on each of them based on two estimation procedures pooling OLS and RE. If the sign of the impact of certain IC variables on productivity changes, contingent on the productivity measure used, we do not have a robust or solid empirical result for policy implementation. However, as we will see later, it is possible to obtain robust and consistent results even when the correlations between the alternative measures of productivity differ dramatically. This basic result allows us to implement reliable policy recommendations. Table $\mathrm{C} 1$ of the appendix reports eight correlations between the log productivity measures obtained from the four single-step production function estimates and from the two Solow residuals.

The results are as follows: when we consider the correlations between the Solow residuals and the productivity measures that comes from estimating restricted production functions, the correlations are very similar in all the cases, ranging from 0.91 to 0.98 . However, the unrestricted production functions differ by industry and therefore we get smaller correlations between those productivity measures, ranging from 0.75 in the Cobb-Douglas case to a correlation of 0.19 in the Translog case.

The econometric analysis based on the 10 different productivity $(\mathrm{P})$ measures is explained in the following subsections. The units of measurement of each explanatory variable are included in Table B.3 of the appendix. Units of measurement are very important for the correct economic interpretation of each coefficient. 


\subsection{Restricted Coefficient Estimates (equal input-output elasticities)}

\section{i) Solow's Residual (Two-step restricted estimation)}

We can estimate the elasticity parameters of the IC variables once we have a measure of productivity $\left(\mathrm{P}_{\mathrm{it}}\right)$. For that we could first obtain the Solow residuals $\left(\mathrm{P}_{\mathrm{it}}\right)$ as in equation (36a) and then estimate the impact of IC variables on $\mathrm{P}_{\text {it }}$ through regression techniques. This twostep approach overcomes the endogeneity problem for the inputs.

First, we take the Solow residuals from (41a), as in Solow (1967) and Hall (1990.) In the restricted case, we obtain the aggregate share $\left(\bar{s}_{r t}\right)$ of each input $r$ of the whole manufacturing sector of the three countries for year $t$.

$$
\log Y_{i t}=\bar{S}_{L, t} \log L_{i t}+\bar{S}_{M, t} \log M_{i t}+\bar{S}_{K, t} \log K_{i t}+\log P_{i t}
$$

where $\bar{s}_{r, t}$ is the average cost shares from all firms during the last two years and is given by $\bar{s}_{r, t}=\frac{1}{2}\left(\underline{s}_{r, t}+\underline{s}_{r, t-1}\right)$, as in equation (36a), and $\underline{s}_{r t}$ is the average of the cost shares of input $\mathrm{r}$, $\mathrm{r}=\mathrm{L}, \mathrm{M}$ and $\mathrm{K}$ across the entire sample of plants from the three countries (restricted case) in year t. From Table C 3.3 of the appendix we have the cost share of labor at 0.36 , the cost share of intermediate materials at 0.53 and that of capital at 0.11 . Note that the elasticities add up to one since we are imposing constant returns to scale (CRS).

Second, we estimate equation (41b) by regression techniques:

$$
\log P_{i t}=\sum_{r=1}^{q_{I C}} \alpha_{I C, r} \log \overline{I C}_{i t,}+\sum_{r=1}^{q_{C}} \alpha_{C, r} \log C_{r, i t}+\alpha_{P}+\sum_{r=1}^{11} \alpha_{D, r} D_{r, t}+u_{i t}
$$

The empirical results of estimating equation (41b) by pooling the observations from the three countries and running OLS and random effects (RE) are in Table C2 of the appendix. Notice 
that none of the IC variables enter nonlinearly. The remaining endogeneity of the $\overline{I C}$ and $\mathrm{C}$ variables is addressed in equations (44b) and (44c) below.

\section{ii) Cobb-Douglas and Translog Productivities (Single-step restricted estimation)}

Consider that the coefficients of the three inputs $(\mathrm{L}, \mathrm{M}, \mathrm{K})$ of the Cobb-Douglas (42) and Translog (43) production functions are constant (see assumption 4.1) for the whole manufacturing sector after pooling the observations from the three countries. That is, $\alpha_{L, i}=$ $\alpha_{L}, \alpha_{M, i}=\alpha_{M}$ and $\alpha_{K, i}=\alpha_{K}$ and therefore equations (34) and (35) become (42) and (43) respectively. Each of the two equations is estimated in a single step, meaning that the parameters of the production function are estimated jointly with the parameters of the IC, C and $\mathrm{D}$ variables. However, to make the empirical results more readable we present them in separate tables in the appendix, see Tables C3.1, C3.2 and C3.3.

In particular, for the Cobb-Douglas production function the specification is:

$$
\begin{aligned}
& \log Y_{i t}=\alpha_{L} \log L_{i t}+\alpha_{M} \log M_{i t}+\alpha_{K} \log K_{i t}+ \\
& \quad+\sum_{r=1}^{q_{I C}} \alpha_{I C, r} \log \overline{I C}_{r, i t}+\sum_{r=1}^{q_{C}} \alpha_{C, r} \log C_{r, i t}+\alpha_{P}+\sum_{r=1}^{11} \alpha_{D, r} D_{r, t}+u_{i t}
\end{aligned}
$$

The empirical results from pooling OLS and random effects (RE) estimators are included in Tables C3.1 and C3.3. Table C3.1 has the estimated elasticities of IC variables on productivity and Table C3.3 has the input-output elasticities of the Cobb-Douglas production function, which for labor is between 0.42 (OLS) and 0.49 (RE), for intermediate materials is between 0.54 (OLS) and 0.45 (RE) and for capital is 0.06 for both. With both estimation procedures, the constant returns to scale (CRS) condition is rejected by the data with a p-value equal to 0 . 
The estimated impacts of IC variables on productivity (P) from Table C3.1 are very similar to those obtained with the Solow residuals in Table $\mathrm{C} 2$ and all the signs of the elasticities are the same.

For the Translog production function,

$$
\begin{aligned}
& \log Y_{i t}=\alpha_{L} \log L_{i t}+\alpha_{M} \log M_{i t}+\alpha_{K} \log K_{i t}+ \\
& \quad+\frac{1}{2} \alpha_{L L}\left(\log L_{i t}\right)^{2}+\frac{1}{2} \alpha_{M M}\left(\log M_{i t}\right)^{2}+\frac{1}{2} \alpha_{K K}\left(\log K_{i t}\right)^{2}+ \\
& +\alpha_{L M}\left(\log L_{i t}\right)\left(\log M_{i t}\right)+\alpha_{L K}\left(\log L_{i t}\right)\left(\log K_{i t}\right)+\alpha_{M K}\left(\log M_{i t}\right)\left(\log K_{i t}\right)+ \\
& \quad+\sum_{r=1}^{q_{I C}} \alpha_{I C, r} \log \overline{I C}_{r, i t}+\sum_{r=1}^{q_{C}} \alpha_{C, r} \log C_{r, i t}+\alpha_{P}+\sum_{r=1}^{11} \alpha_{D, r} D_{r, t}+u_{i t} .
\end{aligned}
$$

The empirical results obtained from the estimation by OLS and random effects (RE) are presented in Tables C3.2 and C3.3 of appendix, even though the parameters were estimated in one step (jointly estimated) from (43). In particular, the elasticities of the IC variables on productivity are in Table $\mathrm{C} 3.2$ and the input-output elasticities are in Table $\mathrm{C} 3.3$.

The estimated elasticities reported in Table C3.2 are again very similar to the ones of Table $\mathrm{C} 2$ and Table $\mathrm{C} 3.1$ and all the signs of the impacts of IC variables are maintained.

With the Translog functional form, the hypothesis that the Cobb-Douglas specification was supported by the data (null hypothesis) was rejected with a p-value of 0 , as shown in Table C3.3. We then tested for CRS in the Translog specification and it was also rejected with the same p-value. 


\subsection{Unrestricted Production Function Coefficients Estimated by Industry}

In the unrestricted case we allow the coefficients of the inputs ( $\mathrm{L}, \mathrm{M}$ and $\mathrm{K}$ ) of the production function to vary by industry. That is, $\alpha_{L, i}=\alpha_{L, j}, \alpha_{M, i}=\alpha_{M, j}$ and $\alpha_{K, i}=\alpha_{K, j}$ for all plants i of the three countries in industry $j$, where $j=1,2, \ldots, 9$. The definitions of the nine $\mathrm{j}$ industries are included in Table A1 of the appendix.

\section{i) Solow's Residuals (Two-step unrestricted estimation)}

For this unrestricted case we first obtain the share $\left(\bar{s}_{r t}\right)$ of each input $r$, where $r=L, M$ and $\mathrm{K}$, for each of the nine manufacturing industries of the three countries for year $t$, to get the Solow residuals (Solow 1967; Hall 1990) from (44a)

$$
\log Y_{i t}=\bar{S}_{L, j t} \log L_{i t}+\bar{S}_{M, j t} \log M_{i t}+\bar{s}_{K, j t} \log K_{i t}+\log P_{i t}
$$

where $\bar{s}_{r, j t}$ is the average industry $\mathrm{j}$ cost shares from the last two years given by $\bar{s}_{r, j t}=\frac{1}{2}\left(\underline{s}_{r, j t}+\underline{s}_{r, j t-1}\right)$, see equation (36a), and $\underline{s}_{j t}$ is the average of the cost shares of input $\mathrm{r}$, $\mathrm{r}=\mathrm{L}, \mathrm{M}$ and $\mathrm{K}$, across the i-plants that belongs to industry $\mathrm{j}$ in year $\mathrm{t}$ from the three countries (restricted case).

The costs shares of each industry are reported in Table C5.3. We can see that there is a certain homogeneity among the nine sectors. Intermediate materials always has the highest share, with almost $50 \%$, followed by the cost share of labor, at nearly $40 \%$ and capital, around $10 \%$.

Second, estimate equation (44b) by regression techniques: 


$$
\log P_{i t}=\sum_{r=1}^{q_{I C}} \alpha_{I C, r} \log \overline{I C}_{i t \zeta}+\sum_{r=1}^{q_{C}} \alpha_{C, r} \log C_{r, i t}+\alpha_{P}+\sum_{r=1}^{11} \alpha_{D, r} D_{r, t}+u_{i t}
$$

The empirical results from the OLS and the random effects estimates of equation (44b) are included in Table C4.1 of appendix. The results are very similar to those previously analyzed in the restricted case of Table $\mathrm{C} 2$.

The endogeneity of IC variables creates a correlation between the IC variables and the errors $\left(\mathrm{u}_{\mathrm{it}}\right)$ in equation (44b). This correlation is mitigated by substituting the plant level IC variables by a region industry average $(\overline{I C})$. If we believe that there is some remaining endogeneity in the $\overline{I C}$ variables, due to the correlation with the perception variables (PE), we can use the information from the survey, to correct for it. As explained in the paragraph preceding equation (38), we could add those variables ${ }^{23}$ into model (44c),

$$
\log P_{i t}=\sum_{r=1}^{q_{I C}} \alpha_{I C, r} \log \overline{I C}_{i t,}+\sum_{r=1}^{q_{C}} \alpha_{C, r} \log C_{r, i t}+\sum_{r=1}^{q_{D}} \alpha_{D, r} D_{r, t}+\sum_{r=1}^{q_{P E_{i}}} \alpha_{P E, r} \log P E_{r, i t}+\alpha_{P}+\eta_{i t} .
$$

The list of (PE) variables used in (44c) are in Table A.4 of the appendix. However, out of the whole set of variables that we have considered, only one of them became significant; the perception the firm has about export experience, as seen in Table C4.2 of the appendix. Notice, however, that most of the previous empirical results about IC variables are

${ }^{23}$ This control function approach is based on the partialling out interpretation of OLS estimators in multiple regression.

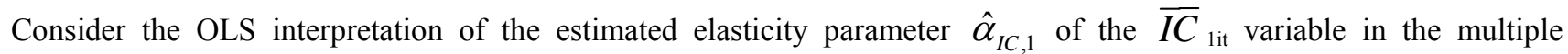
regression equation (44b). When the $\overline{I C}_{1 \text { it }}$ variable is correlated with the error term in (44b), due to the effect of the perception variables (PE) variables, the OLS estimator is biased and inconsistent. On the other hand, the OLS estimator of $\alpha_{I C, r}$ in (44c) is unbiased and consistent. The intuition of the result is the following: the estimated OLS coefficient of $\overline{I C}_{1 \text { it }}$ in (44c) measures the relationship between productivity $\left(\mathrm{P}_{\mathrm{it}}\right)$ and $\overline{I C}_{1 \mathrm{it}}$, after partialling out from $\overline{I C}_{1 \mathrm{it}}$ the effect of all the other explanatory variables of (44c) including PE. 
maintained. Therefore we can interpret the results obtained by estimating equation (44b) with confidence.

ii) Cobb-Douglas and Translog Productivities (Single-step unrestricted estimation by industry)

In this unrestricted case, the production functions specifications derived in equations (34) and (35) become the production functions for each industry $\mathrm{j}$ and are given by equations (45) and (46) respectively. Each equation is estimated by OLS and by random effects (RE) and the parameter estimates are reported in Tables C5.1 to C5.4 in the appendix. Once again, we separate the information on the production function elasticities from the information on the IC elasticities to make the tables more readable although all the parameters were jointly estimated.

Equation (45) is the Cobb-Douglas specification used to estimate, in a single step, the productivity $\left(\mathrm{P}_{\mathrm{it}}\right)$ at the industry level and the IC elasticities and semi-elasticities at the aggregate level. The results are reported in Table C5.1 and C5.3 of the appendix.

$$
\begin{aligned}
\log Y_{i t}= & \alpha_{L, j} \log L_{i t}+\alpha_{M, j} \log M_{i t}+\alpha_{K, j} \log K_{i t}+\sum_{r=1}^{q_{I C}} \alpha_{I C, r} \log \overline{I C}_{r, j t}+\sum_{r=1}^{q_{C}} \alpha_{C, r} \log C_{r, t}+ \\
& +\alpha_{P}+\sum_{r=1}^{q_{D}} \alpha_{D, r} D_{r, t}+u_{i t}
\end{aligned}
$$

Again, pooling the observations from the three countries and estimating by OLS and random effects (RE) give similar results. The constant returns to scale (CRS) condition is only rejected in three of the nine sectors, chemicals/rubber, food/tobacco and leather/shoes with pvalues lower than 0.05. Apparel, beverages, furniture/wood, nonmetallic minerals and textiles fail to reject CRS, as the values of the last column of Table C5.3 of the appendix illustrate. 
For some sectors like leather/shoes, the estimated input-output elasticities are very different from the values obtained from the cost shares given by the two-step procedure with Solow residuals, meaning that the industries have certain heterogeneity in their input-output elasticities. Therefore, the corresponding productivity measures should differ in a significant way. (See the unrestricted cross-correlations by industry given in Table C1.)

The question of interest now is whether these new productivity measures yield similar elasticity and semi-elasticity estimates for the IC effects on P. The results are included in Table C5.1. The results are robust since the signs of the explanatory variables are equal and the range of values reasonable.

Similar single-step procedures are used to estimate the following Translog specification at the industry level. The results are included in Table C5.2 and C5.3.

$$
\begin{aligned}
& \log Y_{i t}=\alpha_{L, j} \log L_{i t}+\alpha_{M, j} \log M_{i t}+\alpha_{K, j} \log K_{i t}+ \\
& \quad+\frac{1}{2} \alpha_{L L, j}\left(\log L_{i t}\right)^{2}+\frac{1}{2} \alpha_{M M, j}\left(\log M_{i t}\right)^{2}+\frac{1}{2} \alpha_{K K, j}\left(\log K_{i t}\right)^{2}+ \\
& +\alpha_{L M, j}\left(\log L_{i t}\right)\left(\log M_{i t}\right)+\alpha_{L K, j}\left(\log L_{i t}\right)\left(\log K_{i t}\right)+\alpha_{M K, i}\left(\log M_{i t}\right)\left(\log K_{i t}\right)+ \\
& +\sum_{r=1}^{q_{I C}} \alpha_{I C, r} \log \overline{I C}_{r, j t}+\sum_{r=1}^{q_{C}} \alpha_{C, r} \log C_{r, i t}+\alpha_{P}+\sum_{r=1}^{q_{D}} \alpha_{D, r} D_{r, t}+u_{i t}
\end{aligned}
$$

The empirical results of the Translog production function parameters are included in Table C5.4. We tested the null hypothesis of constant returns to scale (CRS) in each industry and generated different results from those obtained with the Cobb-Douglas specification. Six out of nine sectors or industries rejected CRS, either by OLS or by random effects. The three sectors that failed to reject CRS are beverages, furniture/wood and textiles. Furthermore, we tested the Cobb-Douglas specification using equation (46) and in five out of nine sectors it was rejected. The industries that failed to reject the Cobb-Douglas specification also failed to reject CRS. 
The Translog results on the empirical estimates of the IC elasticities are the same in terms of signs but fewer number of parameters become significant now, see Table C5.2. Again, the reason is clear: the Translog specification includes many nonlinear terms of the inputs variables of each sector and they compete with the explanatory power of IC variables or C characteristics. The important point is that all the signs of the coefficients of the IC and C variables are maintained. Therefore, the results on the impact of IC variables on productivity are very consistent and robust to different productivity measures, suggesting that we can use the signs and the range of estimated elasticities for policy analysis.

\subsection{Further Productivity Analysis of IC Determinants by Age and Size of the Firms}

The purpose of this section is to evaluate the productivity impact of investment climate (IC) variables at different levels of aggregation of firms' characteristics. In particular, we suggest distinguishing the impact by age and by size of the firm. Since the previous section shows that the analysis is robust to different productivity measures, we will only do the regression analysis for the Solow residuals in levels (or logs), that is, the two-step approach using an extension of equation (44b) estimated by pooling the observations coming from the three countries and estimating the parameters by OLS.

We first start by analyzing in more detail the age of the firm effect. For that we distinguish plants with less than five years of operation (young) from the others (old) in equation (44b). The results of Table C6.1 give a clear message: old firms are more affected by IC variables than young firms. However, when the IC variable is significant for both young and old firms, the difference is not significantly different from 0 .

A different behavior is also observed in Table C6.2 when we distinguish between small (less than 25 workers) and large (26 or more workers) firms. The negative impact of IC variables (mainly those related to transport/logistics) is more relevant for small firms than for large 
ones. For large firms the only IC variable with significant negative elasticity is the one related to crime (number of criminal attempts suffered and the square losses due to crime) which is not significant for small firms. About the positive effects that affect only small firms we should mention the fraction of total staff engaged in R\&D activities, the training provided by the firm beyond "on the job training" and the share of imported inputs. The positive IC variables that affect only large firms are the fraction of computer-controlled machinery and ISO quality certification. When the IC variables affect both small and large firms the difference is not significantly different from zero.

\section{Production Allocation Efficiency by Country, Firm Size and Industry}

To complement the productivity analysis based on regression techniques we perform the allocation efficiency decomposition suggested by Olley and Pakes (1996). This analysis is especially interesting when the industries of some countries have few observations on IC variables. In those cases, we cannot give much credibility to the country-by-country or industry-by-industry regression estimates of the impact of IC variables on productivity since they are based on very small samples. This decomposition provides aditional information which is useful for analyzing the industry efficiency allocation within each country.

Remember from equation (40) that the first term $\left(\bar{P}_{k t}\right)$ of the decomposition is the sample average productivity of firms from industry $\mathrm{k}$ in year $\mathrm{t}$ and the second term $\left(\sum_{i=1}^{N_{k}} \tilde{s}_{k, t} \tilde{P}_{k, i t}\right)$ measures the covariance between productivity and output shares of those firms.

We performed first the Olley and Pakes decompositions on the Solow residual productivity estimates at three different level of aggregation:

\section{- $\quad$ By Country}


First, we constructed a measure of productivity for each of country and decompose it into the average productivity term and the covariance term. The results in Figure 1 show that more productive plants have higher market shares only in Guatemala, i.e. there is an efficient allocation of resources in Guatemala but this is not the case in Honduras and Nicaragua.

- $\quad$ By Size

Second, we construct a measure of productivity for each group of plants - small and large - in each country and we apply the Olley and Pakes decomposition. The results are shown in Figure 2. In Guatemala, resources are again efficiently allocated for small and large plants. In Honduras, the less-productive firms have higher market shares and this negative impact is larger (in absolute value) for small firms. In Nicaragua the results are mixed. Small firm are efficiently allocated while large firms are not.

\section{By Industry and Country}

Third, we construct a measure of productivity for each industry in each country and perform the decomposition. The results are shown in the three panels of Figure 3 of the appendix. In Guatemala, we find an efficient allocation of resources of different intensities in all industries. In Honduras, the allocation of resources is inefficient in all sectors apart from apparel, nonmetallic minerals and metal products. In Nicaragua, there is an efficient allocation of resources in four of the nine industries: chemical/rubber/plastics, food/tobacco, furniture and wood and metal products. These industry-level productivity decompositions should be interpreted with care since in some sectors there are very few observations.

For the first two types of productivity decomposition we extend the analysis to six different productivity measures, to see if the conclusions are robust. The results are in Table C7.1 and C7.2 of the appendix. The signs of the covariance terms of Figure 1 are maintained in each country for the restricted model in all cases but one corresponding to Nicaragua, as Table C7.1 shows. The results of Figure 2 are also maintained when we split the different productivity measures of each country into large and small firms, as Table C7.2 illustrates. 
However, the efficiency results are not robust to alternative productivity measures in the unrestricted models of Honduras and Nicaragua, when we allow the input elasticities to vary by sector in the Cobb-Douglas and Translog specifications, as the last two rows of Tables C7.1 and the last three rows of Tables C7.2 show.

\section{Empirical Results on Investment Climate (IC) Determinants of Productivity in Guatemala, Honduras and Nicaragua}

Before discussing the effects of different IC variables on productivity, it is important to take into account that the economic interpretation of each investment climate coefficient is contingent on the units of measurement of each IC variable and on the transformations performed on them (logs, fractions, percentages, qualitative constructions, etc.). Since productivity variables are always in logs, when the IC variable is expressed in log terms, the estimated coefficient is a constant productivity-IC elasticity; and when the IC variable is not expressed in log form, the estimated coefficient is generally described as a productivity-IC semi-elasticity ${ }^{24}$. While the constant productivity-IC elasticity measures the percentage change in productivity induced by a percentage change in the IC variable, the semi-elasticity coefficient multiplied by 100 , measures the percentage change in productivity induced by a unitary change in the IC variable. A detailed explanation of the units of measurement of each variable is given Table B.3.

\footnotetext{
${ }^{24}$ While it is sometimes natural to express an IC variable in log form, for some types of IC variables it is more appropriate not to do so. For example, when an IC variables is a fraction or a percentage number with some data equal to 0 or close to 0 . Notice however that expressing IC variables in fractions allow us to interpret also their coefficients as constant elasticities and not as semi-elasticities.
} 
Investment climate (IC) variables were classified into key broad categories: (a) Red Tape, Corruption and Crime, (b) Infrastructure, (c) Quality, Innovation and Labor Skills, (d) Finance and Corporate Governance. Within each group, all IC variables have the expected signs and the estimated elasticities or semi-elasticities were always within a reasonable range of values for the 10 productivity measures considered. In absolute terms, the higher elasticity values correspond to the Solow residual or to the Cobb-Douglas specification, while the lowest usually correspond to the Translog production function. Therefore, we observe a tradeoff between the role played by inputs (labor, intermediate materials and capital) and the role played by the IC variables and other control variables. The robustness of these empirical results across productivity measures allows us to obtain consistent evaluations of the IC determinants of productivity.

The main empirical results are presented in three sections that discuss the:

- Productivity elasticities or semi-elasticities of IC variables for the pool of three countries (Guatemala, Honduras and Nicaragua); the

- Country specific percent productivity gains or losses of each IC variable, relative to log productivity; and the

- Olley and Pakes productivity decomposition for each country.

\subsection{Productivity Elasticities or Semi-elasticities of Each IC Variable}

Here we present the individual estimates and interpretation of the elasticities or semielasticities of IC variables on productivity and $\% \mathrm{R}^{2}$ contribution of each IC variable to productivity for the pool of three countries. (See Table D and Figure 1.) For each group of IC variables we give the range of values of productivity impact obtained for the elasticities (minimum and maximum values ) coming from the different productivity measures used. Figure 1 shows the average levels of the elasticities or semi-elasticities of each IC variable, 
listed under the four thematic categories of IC variables. Additional grouping of other control variables is also included.

\section{A. Red Tape, Corruption and Crime}

a.

Number of days spent in inspection and regulation related controls. The semielasticities range from -0.058 to -0.107 . Therefore, if plants dedicate one more day to inspection and regulation control activities, the productivity will decrease between $5.8 \%$ and $10.7 \%$. This is most relevant for old firms.

b. Fraction of sales undeclared to Internal Revenue Service (IRS) for tax purposes. The elasticities are between -0.42 and -0.77 . Meaning that a one percent increase in the fraction of undeclared sales to IRS will decrease productivity between 0.42 and 0.77 percent. The impact is specially important in small plants.

c. $\quad$ Payments to speed bureaucracy "faster" as a \% of sales. Those firms that win a competitive advantage by making payments of $1 \%$ of the sales to "speed up" bureaucratic issues will have an increases in productivity ranging from 1.3 to 3.3 percent. Therefore elasticity ranges from 1.3 to 3.3. In terms of policy recommendations, it is clear that there is room for improvement in the administrative procedures followed in the three countries (Guatemala, Honduras and Nicaragua), so that no more arbitrary administrative gains in productivity arises from bribes of firms.

d. Crime. Number of criminal attempts suffered by the plants. The semi-elasticity on productivity is between -0.018 to -0.032 . For every new criminal attempt suffered by the firm the productivity is reduced between 1.8 and 3.2 percent. This is most relevant in old and large firms.

\section{B. Infrastructure}




\section{Econometric Methodologies for Investment Climate Assessments on Productivity}

e. Power (average duration of power outages). The range of values of the constant elasticities is between -0.024 and -0.095 . The interpretation is the following: a one percent increase in the average duration (hours per day) of power outages decreases productivity between 0.02 and 0.1 percent, depending on the productivity measure used. It mainly affects old plants.

f.

Transportation. Several measures a re considered. First, the average number of days to clear customs for imports. The range of values of the constant elasticities is between -0.097 and -0.125 . Therefore, a one percent increase in the average number of days to clear customs will decrease productivity by a 0.1 percent. It specially affects young and small plants. Second, shipment losses (fraction of sales lost) due to breakage, theft, spoilage or other deficiencies of the transport mean used. The range of the elasticities is between -1.23 and -2.53 , meaning that a one percent increase in the fraction of shipment losses will decrease productivity between 1.23 and 2.53 per cent. This is most important in old and small firms.

g.

Telecommunications (dummy for internet access). Having access to internet has an impact (semi-elasticity) on productivity between 0.11 and 0.15 , meaning that those firms with access to internet are between $11 \%$ and 15\% more productive that those firms without it. The impact is especially relevant in old firms.

\section{Quality, Innovation and Labor Skills}

h. Fraction of computer controlled machinery. The constant elasticities range from 0.084 to 0.132 . Therefore, if the plants increase by one percent their fraction of computer controlled machinery the productivity increase will be 0.1 percent. This is relevant in old and large firms. 


\section{Econometric Methodologies for Investment Climate Assessments on Productivity}

i.

Fraction of total staff engaged in R\&D activities. The elasticities vary from 0.580 to 0.667 . The interpretation is the following, if the plants increase the fraction of total staff dedicated to R\&D activities by $1 \%$ the productivity will increase between 0.6 and $0.7 \%$. The most important impact is on old and small firms.

j. Dummy for ISO quality certification. When the firm is engaged in a process of ISO quality certification its productivity will increase between 2.4 and 17.6 percent (semielasticity). This is especially relevant for large firms.

k. Fraction of total staff (including management) with secondary education or more. The constant elasticities range from 0.03 to 0.06 . That is, a one percent increase in the fraction of total staff with secondary education of the firm implies an increase in productivity between 0.03 and 0.06 percent.

1. Dummy for training by the firm other than on the job training. If a firm engages in a training program for their workers, other than on the job training, they will experience an increase in productivity ranging from 8.9 to 11.7 percent (semi-elasticity). This is especially relevant for small plants.

\section{Finance and Corporate Governance}

m. Dummy for incorporated company. By becoming publicly listed a firm will increase its productivity between 11.5 and 15 percent (semi-elasticity).

n. Dummy for external audit of the financial statements. A firm, by engaging in an external audit of its financial statements, can increase its productivity between 11.6 and 17 percent (semi-elasticity).

\section{E. Other Control Variables}




\section{Econometric Methodologies for Investment Climate Assessments on Productivity}

o.

Age of the firm (in logs). If the experience of a firm in the market, measured

by age, increases by one percent then productivity will increase between 0.03 and 0.05 percent.

p. Share (fraction) of imported inputs. If the fraction of imported inputs of production is increased by one percent then productivity will increase $0.1 \%$. This is most relevant for old and small firms. 


\section{Figure 1}

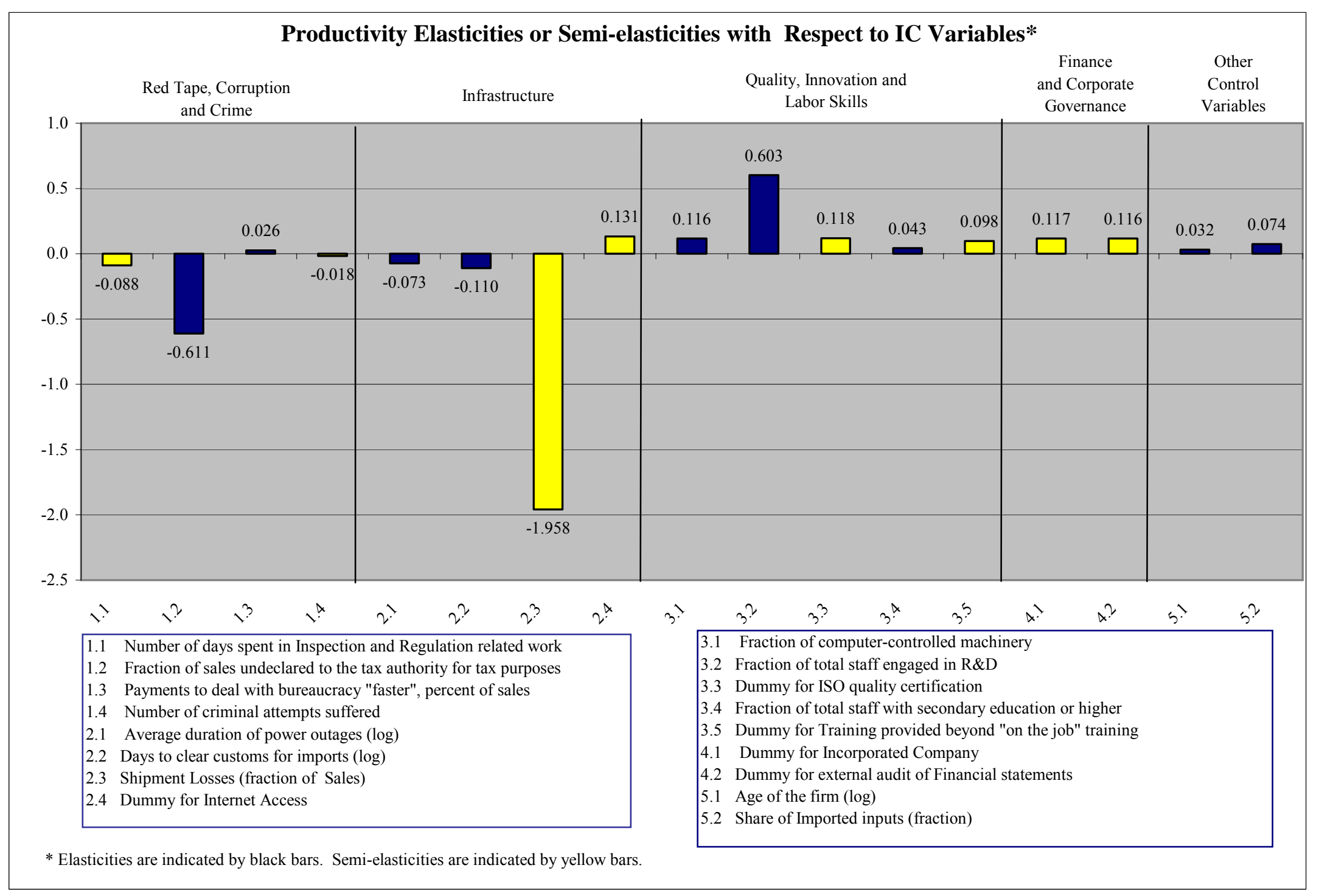


The previously reported elasticities were common to the three countries. To provide country specific estimates of the impact of each IC variable on productivity, we decompose the average productivity of each country into the contribution of the country's average IC variables. We calculate this contribution for different productivity measures and report the minimum and maximum values (range) obtained. ${ }^{25}$ Country specific productivity impacts (gains or losses), in percentage terms, of each IC variable relative to log-productivity, are presented in Tables E1 to E3. Figures 2, 3 and 4, show the average contribution of each IC variable to the average log-productivity for each country (in percentage terms). Figures 5 and 6 show the cumulative productivity effect of the IC variables for each one of the four broad categories plus the control variables. Figure 5 shows the simple cumulative effect and Figure 6 the absolute cumulative effect.

\section{A. Red Tape, Corruption and Crime}

a. Number of days spent in inspection and regulation related controls. For each country, the contribution to the average productivity of the average number of days spent in inspection and regulation related work is:

Guatemala: between -2.0 and -6.2 percent

Honduras: between -2.2 and -6.7 percent

Nicaragua: between -2.6 and -8.4 percent.

The negative contribution of the average number of days spent in inspection and regulation related work is larger, in absolute value, in Nicaragua than in Guatemala and Honduras.

b. Fraction of sales undeclared to IRS for tax purposes. For each country, the contribution to the average productivity of the average fraction of sales undeclared to IRS for tax purposes in each country is:

\footnotetext{
${ }^{25}$ To understand how those IC productivity contributions are calculated, see comments after equation (36b).
} 
Guatemala: between -1.7 and -4.0 percent

Honduras: between -2.4 and -5.5 percent

Nicaragua: between -2.8 and -6.7 percent.

The negative contribution of the average fraction of sales undeclared to IRS for tax purposes is smaller, in absolute value, in Guatemala than in Honduras and Nicaragua.

c.

Payments to deal with bureaucracy "faster" as a \% of sales. Those firms that win a competitive advantage by making payments to "speed up" bureaucratic issues will have a contribution to the country's average productivity:

Guatemala: between 0.8 and 2.8 percent

Honduras: between 0.5 and 1.8 percent

Nicaragua: between 0.4 and 1.5 percent.

The firms from Guatemala that win a competitive advantage by making payments to "speed up" bureaucratic issues have a larger contribution to the average productivity than those of Honduras and Nicaragua

d. Crime. Number of criminal attempts suffered by the plants. For each country, the contribution to the average productivity of the average number of criminal attempts is:

Guatemala: between -0.7 and -2.3 percent

Honduras: between -0.3 and -0.9 percent

Nicaragua: between -0.2 and -0.7 percent.

The negative productivity contribution of the average number of criminal attempts is larger, in absolute value, in Guatemala than in Honduras and Nicaragua.

\section{B. Infrastructure}

e. Power (average duration of power outages). The negative contribution of the average duration of power outages to the average productivity is similar for Honduras and Guatemala and is smaller in absolute value for Guatemala. For each country, the contribution to the average productivity of the average duration of power outages is:

Guatemala: between -0.3 and -1.7 percent 
Honduras: between -0.5 and -2.9 percent

Nicaragua: between -0.5 and -2.8 percent.

The negative contribution of the average duration of power outages is similar for Honduras and Nicaragua and is smaller, in absolute value, for Guatemala.

f. Transportation. First, the average number of days to clear customs for imports.

The contribution to the country's average productivity of the average number of days to clear customs for imports is:

Guatemala: between -4.4 and -5.8 percent

Honduras: between -3.0 and -4.0 percent

Nicaragua: between -3.2 and -4.3 percent.

The negative contribution of the average number of days to clear customs for imports is larger, in absolute value, for Guatemala than for Honduras and Nicaragua.

g.

Transportation. Second, shipment losses (fraction of sales lost) due to breakage, theft, spoilage or other deficiencies of the transport mean used. For each country, the contribution to the average productivity of the average fraction of shipment losses is:

Guatemala: between -0.4 and -1.0 percent

Honduras: between -0.4 and -1.0 percent

Nicaragua: between -0.5 and -1.1 percent.

The negative contribution to the average productivity of the average fraction of shipment losses is similar for the three countries.

h. Telecommunications (dummy for internet access). For each country, the contribution to the average productivity of the probability that a firm has access to internet is:

Guatemala: between 1.3 and 2.7 percent

Honduras: between 0.9 and 1.9 percent

Nicaragua: between 0.8 and 1.6 percent.

The positive contribution of the probability that a firm has access to internet is larger for Guatemala than for Honduras and Nicaragua. 


\section{Quality, Innovation and Labor Skills}

i. Fraction of computer controlled machinery. The contribution to the country's average productivity of the country's average fraction of computer controlled machinery is:

Guatemala: between 0.1 and 0.2 percent

Honduras: between 0.1 and 0.2 percent

Nicaragua: 0.1 percent.

The positive contribution of the average fraction of computer controlled machinery is similar in all countries.

j. Fraction of total staff engaged in R\&D activities. For each country, the contribution to the average productivity of the average fraction of total staff in R\&D activities is:

Guatemala: between 0.1 and 0.7 percent

Honduras: between 0.3 and 0.4 percent

Nicaragua: between 0.4 and 0.6 percent.

The positive contribution of the average fraction of total staff in $R \& D$ activities is similar for the three countries.

k. Dummy for ISO quality certification. For each country, the contribution to the average productivity of the probability of the firm engaging in a process of ISO quality certification is:

Guatemala: between 0.0 and 0.1 percent

Honduras: between 0.1 and 0.2 percent

Nicaragua: between 0.1 and 0.2 percent.

The positive contribution of the probability of the firm engaging in a process of ISO quality certification is similar for the three countries.

1. Fraction of total staff (including management) with secondary education or more. The contribution to the country's average productivity of the country's average fraction of total staff with secondary education or more is: 
Guatemala: between 0.1 and 0.5 percent

Honduras: between 0.1 and 0.4 percent

Nicaragua: between 0.2 and 0.5 percent.

The positive contribution of the average fraction of total staff with secondary education or more is similar for the three countries.

m. Dummy for training by the firm other that on the job. For each country, the contribution to the average productivity of the probability of a firm engaging in a training program for their workers other than on the job training is:

Guatemala: between 0.9 and 1.6 percent

Honduras: between 0.8 and 1.8 percent

Nicaragua: between 0.7 and 1.2 percent.

The positive contribution of the probability of a firm engaging in a training program for their workers, other than on the job training is similar for the three countries.

\section{Finance and Corporate Governance}

n. Dummy for Incorporated Company. The contribution to the country's average productivity of the probability of firms becoming publicly listed is:

Guatemala: between 1.1 and 2.3 percent

Honduras: between 0.5 and 1.0 percent

Nicaragua: between 0.7 and 1.5 percent.

The positive contribution of the probability of firms becoming publicly listed is larger for Guatemala than for Honduras and Nicaragua.

o.

Dummy for external audit of the financial statements. The contribution to the country's average productivity of the probability that the firms engage in an external auditing of its financial statements is:

Guatemala: between 0.7 and 1.5 percent

Honduras: between 0.8 and 1.8 percent

Nicaragua: between 0.6 and 1.3 percent. 
The contribution of the probability that the firms engage in an external auditing of its financial statements is similar for the three countries.

\section{E. Other Control variables}

p. $\quad$ Age of the firm (in logs). Let firm's experience in the market be measured by its age. Then, the contribution to the country's average productivity of the average age of the firm (in logs) is:

Guatemala: between 1.4 and 3.4 percent

Honduras: between 1.2 and 3.1 percent

Nicaragua: between 1.5 and 3.6 percent.

The experience of the firm in the market, measured by age, has a positive contribution to the country's average productivity and is of similar magnitude in the three countries.

q. Share (fraction) of imported inputs. For each country, the contribution to the average productivity of the average fraction of imported inputs for production is:

Guatemala: between 0.6 and 1.1 percent

Honduras: between 0.5 and 0.9 percent

Nicaragua: between 0.7 and 1.2 percent.

The positive contribution of the average fraction of imported inputs for production is similar for the three countries.

A summary of the estimated values of the elasticities and semi-elasticities of productivity with respect to investment climate variables is provided in Figure 1. It represents the average values of the six elasticity estimates given in Table $\mathrm{D}$ of the appendix. 
Figure 2

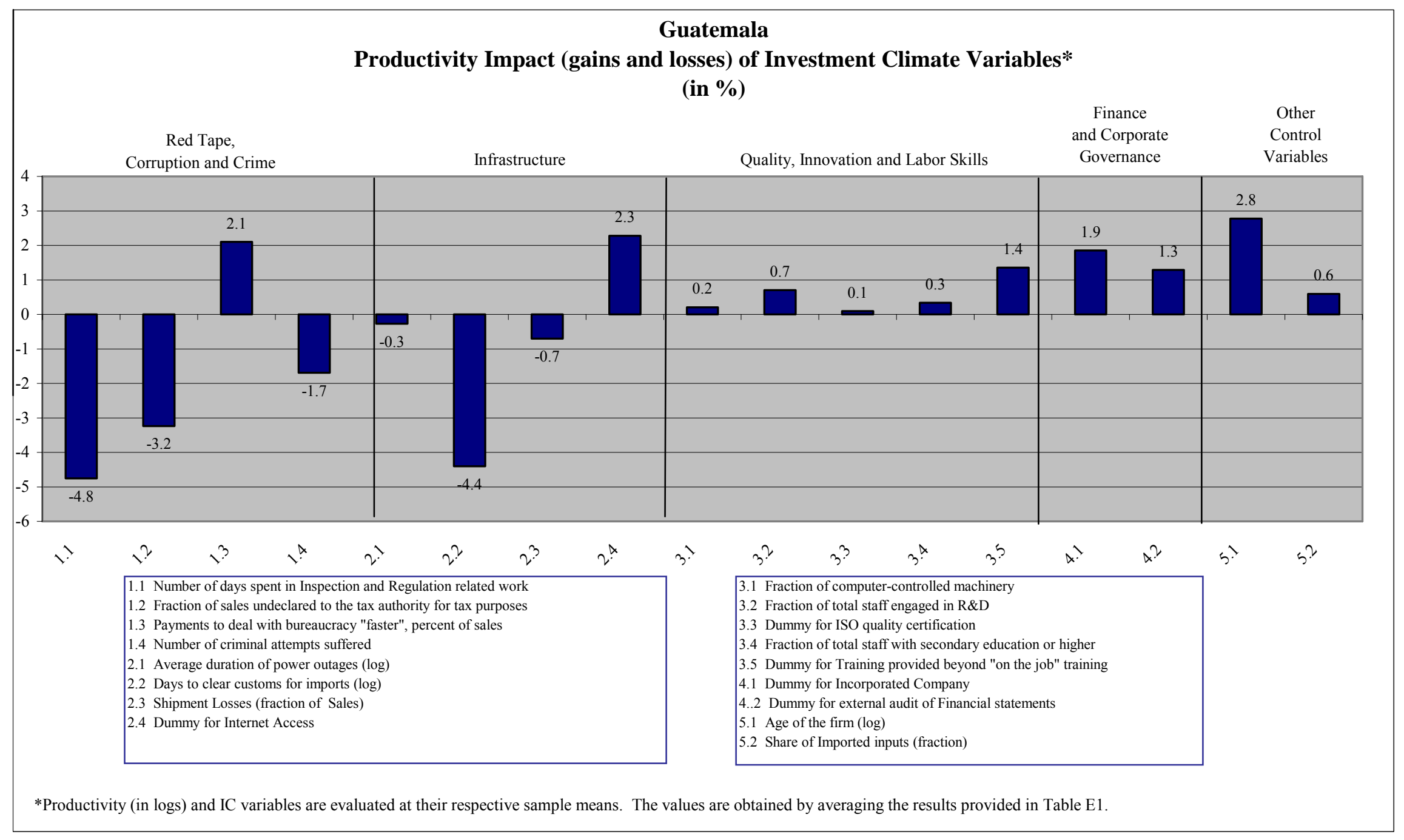


Figure 3

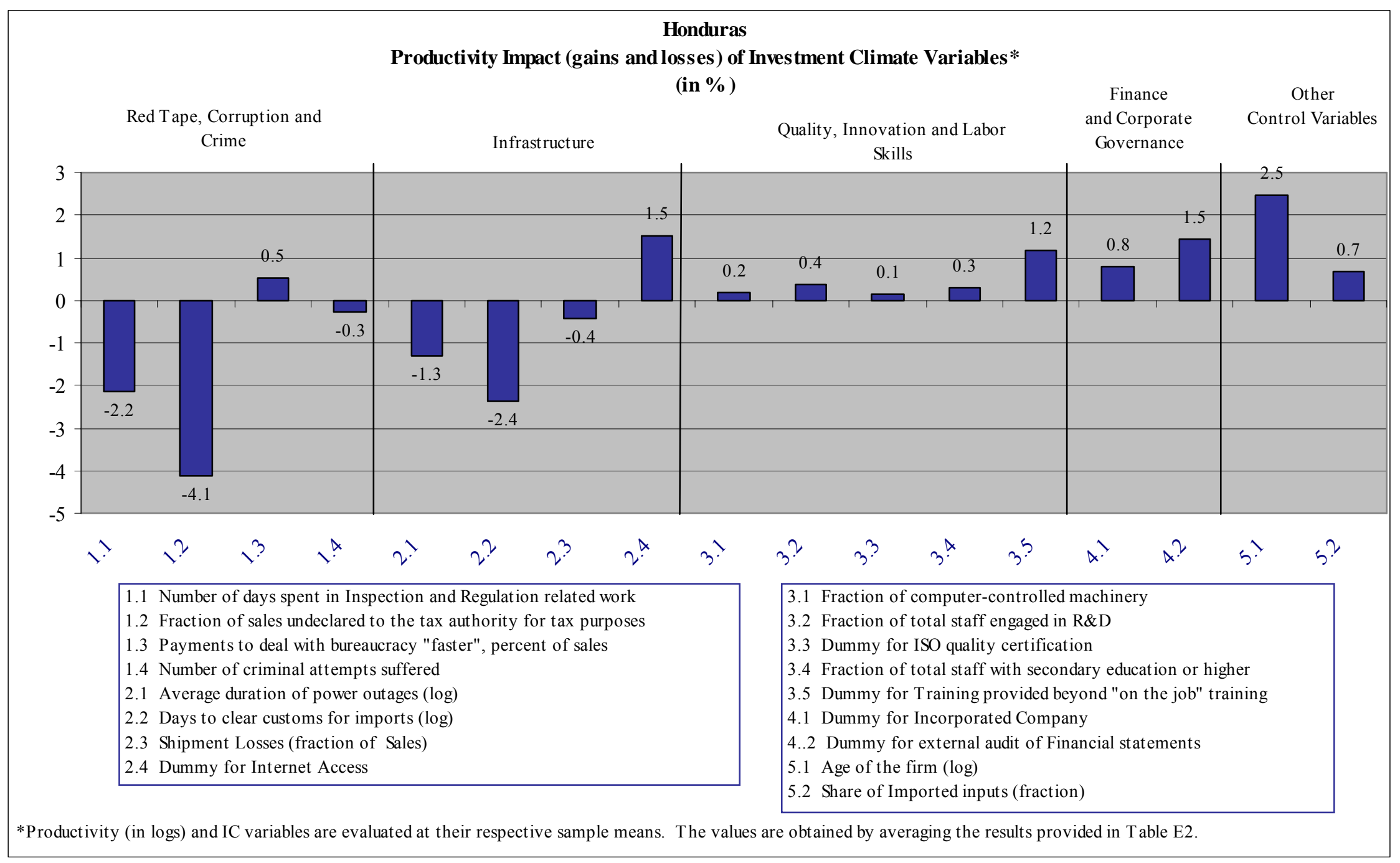




\section{Figure 4}

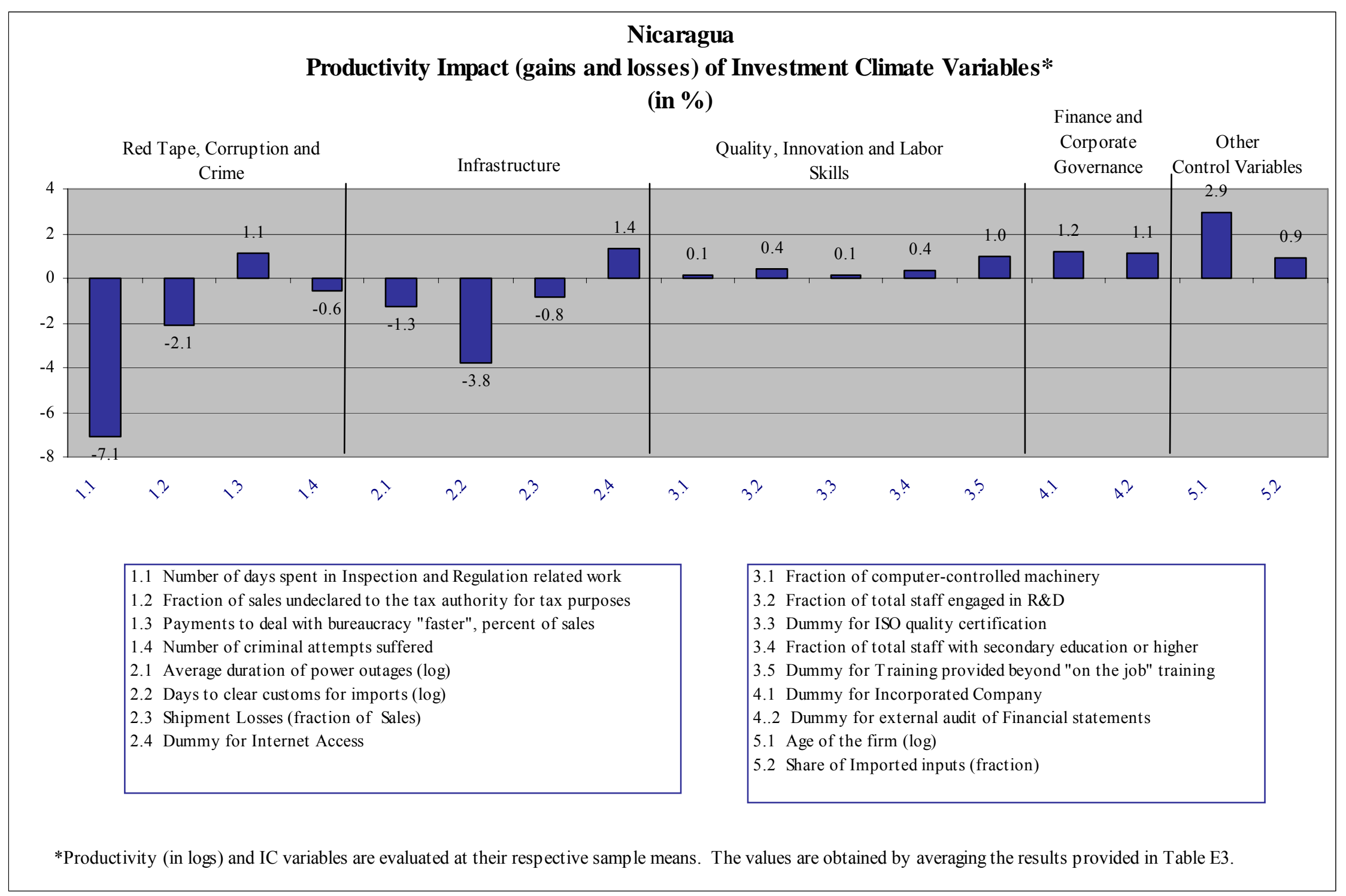


Figure 5

Productivity Impact in Guatemala, Honduras and Nicaragua due to Investment Climate Variables (in \%)

(Cummulative Contribution)

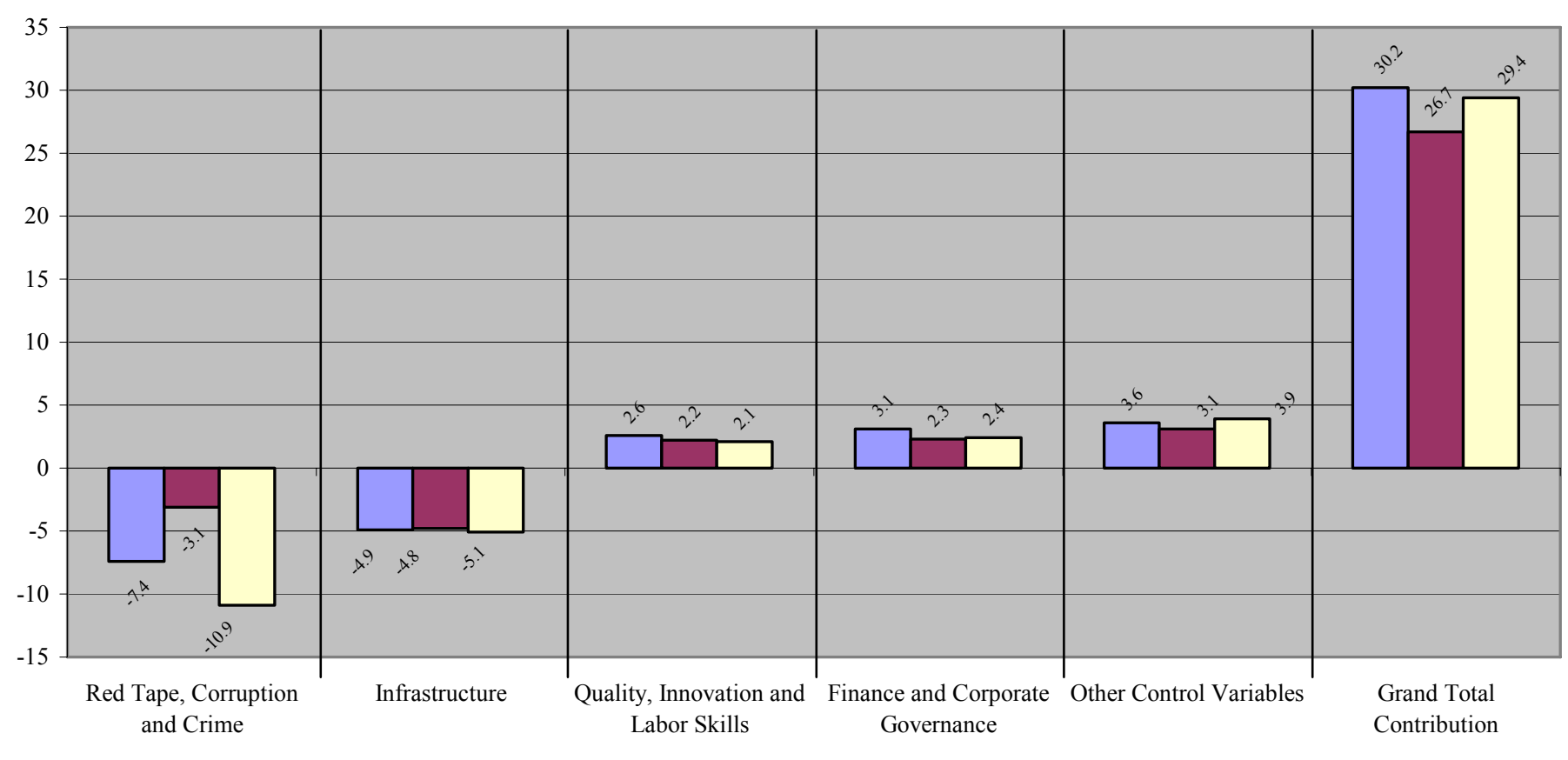


Figure 6

\section{Productivity Impact in Guatemala, Honduras and Nicaragua due to Investment Climate Variables (in \%) \\ (Cummulative Absolute Contribution)}

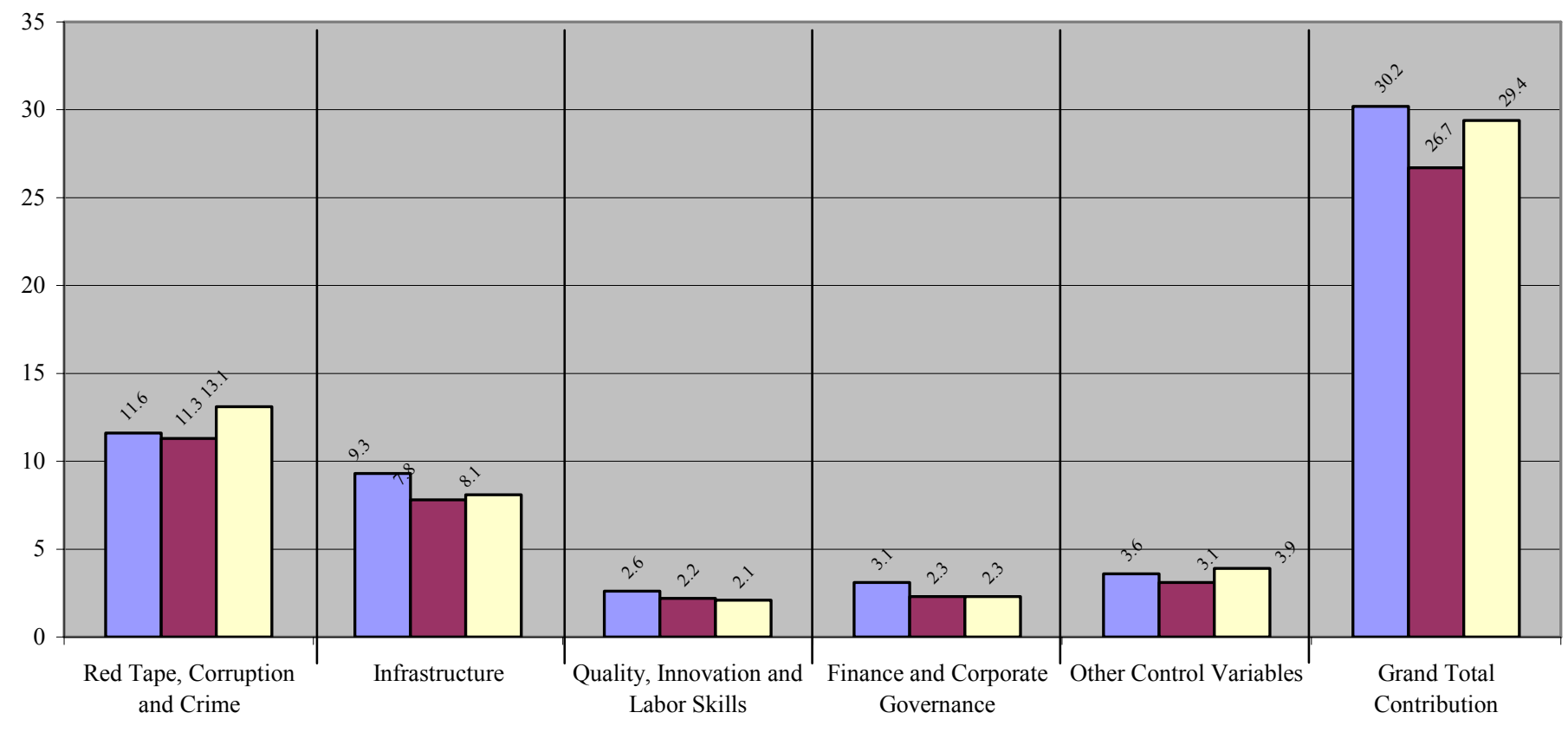




\subsection{Olley and Pakes (1996) Productivity Decomposition for Each Country}

Olley and Pakes (1996) productivity decomposition for each country, see Figure 7 to Figure 9 and Tables C7.1 and C7.2 in the Annex.

The Olley and Pakes decomposition provides additional insights on the efficiency of the allocation of resources in each country. The country's aggregate productivity (weighted by the share of sales of each firm) is decomposed as the (unweighted) average productivity term and the covariance productivity term. The larger is the positive covariance term, the higher is the share of sales made by more productive plants, thus increasing the industry's productivity (efficiency). The more negative is the covariance term, the higher is the share of sales made by less productive plants, reducing industry productivity (inefficiency).

Figure 7 shows the decomposition for the three countries for the case where productivity is obtained as the Solow residual. Guatemala has a positive covariance productivity term while Honduras and Nicaragua have a negative covariance. Therefore, in Guatemala the most productive firms have the highest share of sales while in Honduras and Nicaragua the less productive firms have the largest share of the market. The efficiency picture is maintained for Guatemala when we split the sample into small and large firms, but it changes for Honduras and Nicaragua. In the case of Honduras, the aggregate negative productivity covariance is mainly obtained because of small firms. Therefore, in Honduras small firms allocate resources more inefficiently than large firms. For Nicaragua, the negative aggregate productivity covariance comes from the dominant negative covariance of large firms. Therefore, in Nicaragua small firms allocate resources more efficiently than large firms.

The analysis can be applied to other productivity measures to check the robustness of the covariance results. The signs of the covariance terms of Figure 7 are maintained in each country for the restricted model, except for one of the productivity measures in Nicaragua, see Table C7.1. The results of Figure 8 are also maintained when we consider large and small firms, see Table C7.2. However, the efficiency results are not robust to alternative productivity measures in the unrestricted models of Honduras and Nicaragua, when we allow 
the input elasticity to vary across sectors in the Cobb-Douglas and Translog specifications, see the last two rows of Tables C7.1 and the last three rows of Tables C7.2. This is because we have very few observations in some of the industries.

\section{Conclusion}

There is not a single salient measure of productivity. For the analysis of the investment climate (IC) determinants of productivity in Guatemala, Honduras and Nicaragua, productivity is considered to be that part of the production of goods (sales) that is not explained by the main inputs (labor, intermediate materials and capital). This productivity concept is sometimes called total factor productivity (TFP) or multifactor productivity (MFP).

Several measures are used to evaluate what is broadly understood as productivity and a methodology is developed that produces robust estimates regardless of the measure used. We show that it is possible to get consistent and robust estimates (elasticities) of investment climate determinants of productivity. This is so no matter whether we use productivity measures with a low correlation coefficient, such as 0.19 (very different), or a high one, such as 0.98 (similar).

The main requirement of this econometric methodology for internal consistency is that the policy implications must be robust: 1) among different functional forms of the production functions, 2) among different consistent estimation procedures, 3) among different productivity measures and 4) among different levels of aggregation (industry, country, pooling countries, etc.). In our case, all the signs of the estimated coefficients are as expected. Obviously, the numerical values of those elasticity parameters vary from one productivity measure to the next, but the range of values is reasonable and significant in most cases.

The analysis is undertaken without transforming the variables into rates of growth. There are good reasons explaining that decision: (a) the IC variables are available for only one year; (b) the panel data are very unbalanced with many more observations in 2002 than in 2001, hence computing rates of growth for the non IC variables implies losing many observations; and (c) measurement errors are enhanced by taking first differences. Therefore, variables in levels are 
used with logarithmic (logs) transformation of output, labor, intermediate materials and capital.

Productivity is estimated as the residual of the production function. To get consistent least squares estimates of the input-output elasticities it is necessary that all inputs are uncorrelated with productivity. But this is almost never the case with annual data sets since the investment climate (IC) variables affect both the inputs and the productivity. This condition invalidates any two-step least squares procedures where first the productivity variable and then its investment climate determinants are estimated. This problem also affects all procedures that assume that the labor input is uncorrelated with productivity, such as those in Olley and Pakes (1996) or Levinsohn and Petrin (2003).

Given that good instrumental variables are not available for the IC variables, we suggest a single-step least squares estimation procedure where the parameters of the production function (input-output elasticities) are jointly estimated with the coefficients of the IC determinants of productivity.

A valid two-step approach is also used when the input-output elasticities are obtained, following Solow (1957), as cost-shares. Once productivity is measured as the Solow residual in levels (logs), the IC determinants of productivity can be consistently estimated in a second step.

The possible endogeneity of the IC variables is reduced by taking their region-industry averages and using the control function approach based on IC variables' perceptions. To correct for heteroskedasticity (heterogeneity) of the individual unobserved terms, we estimate by least squares (pooling OLS) with robust standard errors and by random effects. The results obtained are very similar.

For policy analysis there is no need to use a single value for the elasticity or semi-elasticity of each IC variable. In fact, it is more interesting to perform a sensitivity analysis based on the range of parameter values obtained for several productivity measures. 
Further insight on the efficiency of the different manufacturing sectors at the country level is obtained from the Olley and Pakes productivity decompositions.

Four important categories of investment climate (IC) variables are identified for the case of Guatemala, Honduras and Nicaragua: (a) read tape, corruption and crime, (b) infrastructure, (c) quality, innovation and labor skills, and (d) finance and corporate governance. Within each group, all the IC variables always have the expected signs and the estimated elasticities or semi-elasticities are always within a reasonable value range for the 10 productivity measures considered. In absolute terms, the higher values of the IC elasticities correspond to the Solow residual or to the Cobb-Douglas specification, while the lowest usually correspond to the translog production function. Therefore, we observe a trade-off between the role played by the inputs (labor, intermediate materials and capital) and the role played by the IC variables and other control variables.

The robustness of these empirical results across productivity measures allows us to obtain consistent empirical evaluations of the IC determinants of productivity. The estimates show consistently the high impact of investment climate on productivity. Overall, it accounts for over 30 percent of productivity. The two most impacting categories are red tape, corruption and crime, and infrastructure, accounting respectively for about 12 and 9 percent of productivity. The policy implications are clear. Investment climate matters enormously and the relative size of the impact of the various investment climate variables indicates where the reform efforts should be placed. 


\section{Appendix}

Table A.1: General Information at Plant Level and Production Function Variables

\begin{tabular}{|c|c|c|}
\hline & Industrial classification & $\begin{array}{l}\text { Apparel, beverages, chemicals/rubber, food/tobacco, furniture/wood, } \\
\text { leather/shoes, nonmetallic minerals, textiles, metal products. }\end{array}$ \\
\hline $\begin{array}{l}\text { General } \\
\text { Information at } \\
\text { Plant Level }\end{array}$ & Regional classification & $\begin{array}{l}\text { - Guatemala: Guatemala City, Metropolitan area close to Guatemala city, } \\
\text { Metropolitan area far from Guatemala city, Altiplano region, Coastal } \\
\text { region, Northeast region } \\
\text { - Honduras: Western region, Center-South region, Olancho region, North } \\
\text { coast region } \\
\text { - Nicaragua: Managua region, Pacific region. }\end{array}$ \\
\hline \multirow{5}{*}{$\begin{array}{l}\text { Production } \\
\text { Function } \\
\text { Variables }\end{array}$} & Sales & $\begin{array}{l}\text { Used as the measure of output for the production function estimation. For } \\
\text { all countries, sales figures in local currency are converted into USD using } \\
\text { IMF average exchange rates. }\end{array}$ \\
\hline & Employment & Total number of permanent workers. \\
\hline & Materials & $\begin{array}{l}\text { Total costs of intermediate and raw materials used in production } \\
\text { (excluding fuel). For all countries, materials figures in local currency are } \\
\text { converted into USD using IMF average exchange rates. }\end{array}$ \\
\hline & Capital stock & Book value of all fixed assets. \\
\hline & Labor cost & Total expenditures on personnel. \\
\hline
\end{tabular}


Table A.2: Investment Climate (IC) Variables

\begin{tabular}{|c|c|c|}
\hline \multirow{10}{*}{ Infrastructure } & Power interruptions & $\begin{array}{l}\text { total duration of power outages suffered by the plant in hours (equals } \\
\text { average duration times the total number of power outages). If the plant } \\
\text { suffered no power outages the total duration of power outages is } 0 \text {. }\end{array}$ \\
\hline & $\begin{array}{l}\text { Duration of power } \\
\text { outages }\end{array}$ & average duration of power outages suffered by the plant in hours. \\
\hline & Power outages & number of power outages suffered by a plant in 2002 . \\
\hline & $\begin{array}{l}\text { Losses due to power } \\
\text { outages }\end{array}$ & $\begin{array}{l}\text { value of the losses due to the power outages as a percentage of sales } \\
\text { (conditional on the plant reporting power outages). }\end{array}$ \\
\hline & $\begin{array}{l}\text { Production interruption } \\
\text { due to power outages }\end{array}$ & $\begin{array}{l}\text { dummy variable }=1 \text { if the plant had to stop production due to power } \\
\text { outages. }\end{array}$ \\
\hline & Phone interruptions & $\begin{array}{l}\text { total duration of phone interruptions suffered by the plant in hours } \\
\text { (equals average duration times the total number of phone outages). If the } \\
\text { plant suffered no phone interruptions the total duration of phone } \\
\text { interruptions is } 0 \text {. }\end{array}$ \\
\hline & Wait for phone & $\begin{array}{l}\text { number of days the plant had to wait from the moment it requested a } \\
\text { phone connection until the day it received the phone service. }\end{array}$ \\
\hline & $\begin{array}{l}\text { Days to clear customs for } \\
\text { imports }\end{array}$ & $\begin{array}{l}\text { average number of days that it took from the time the plant's imports } \\
\text { arrived to the point of entry until the time the plant could claim them } \\
\text { from customs. }\end{array}$ \\
\hline & $\begin{array}{l}\text { Fraction of shipment } \\
\text { losses }\end{array}$ & $\begin{array}{l}\text { fraction of the value of the plant's average cargo consignment that was } \\
\text { lost in transit due to breakage, theft, spoilage or other deficiencies of the } \\
\text { transport means used. }\end{array}$ \\
\hline & $\begin{array}{l}\text { Production stopped due to } \\
\text { transport interruptions }\end{array}$ & $\begin{array}{l}\text { dummy variable }=1 \text { if the plant had to stop production due to transport } \\
\text { interruptions }\end{array}$ \\
\hline \multirow{4}{*}{$\begin{array}{l}\text { Bureaucracy/ } \\
\text { Corruption }\end{array}$} & Inspection days & $\begin{array}{l}\text { number of days spent by the plant in inspections and compulsory } \\
\text { meetings with public officials from the following areas: tax inspectorate, } \\
\text { labor and social security, fire and building. }\end{array}$ \\
\hline & $\begin{array}{l}\text { Percentage of time spent } \\
\text { dealing with regulation }\end{array}$ & $\begin{array}{l}\text { percentage of time in a typical week spent by management dealing with } \\
\text { bureaucracy/regulation. }\end{array}$ \\
\hline & $\begin{array}{l}\text { Payments to deal with } \\
\text { bureaucracy "faster" }\end{array}$ & payments to "speed up" bureaucratic issues as a percentage of sales. \\
\hline & $\begin{array}{l}\text { Fraction of sales } \\
\text { undeclared to the IRS }\end{array}$ & $\begin{array}{l}\text { Fraction of total sales unreported to the IRS for tax purposes by a typical } \\
\text { firm in an area of activity as perceived by the reporting firm }\end{array}$ \\
\hline \multirow{2}{*}{ Crime } & $\begin{array}{l}\text { Losses due to crime as a } \\
\% \text { of sales }\end{array}$ & $\begin{array}{l}\text { value of the plant's losses due to criminal activity as a percentage of } \\
\text { sales. For plants reporting no criminal activity the value of the variable } \\
\text { is } 0 \text {. }\end{array}$ \\
\hline & $\begin{array}{l}\text { Number of criminal } \\
\text { attempts suffered }\end{array}$ & $\begin{array}{l}\text { number of crimes is the number of criminal attempts suffered by the } \\
\text { plant. }\end{array}$ \\
\hline \multirow[b]{3}{*}{ Finance } & Overdraft & $\begin{array}{l}\text { dummy variable }=1 \text { if the plant reports that it has an overdraft facility or } \\
\text { a line of credit. }\end{array}$ \\
\hline & Loan & dummy variable $=1$ if the plant reports that it has a bank loan. \\
\hline & $\begin{array}{l}\text { Constrained access to } \\
\text { loan }\end{array}$ & $\begin{array}{l}\text { dummy variable }=1 \text { if } i \text { ) the plant did not ask for a loan (except if the } \\
\text { plant did not ask for a loan because it did not need it) or ii) the plant } \\
\text { asked for a loan but its request was refused by the bank. }\end{array}$ \\
\hline
\end{tabular}




\section{Table A.3: Other IC and Plant Characteristics (C) Variables}

\begin{tabular}{|c|c|c|}
\hline \multirow{17}{*}{$\begin{array}{l}\text { Other IC and } \\
\text { Plant } \\
\text { Characteristics }\end{array}$} & $\begin{array}{l}\text { Percentage of computer- } \\
\text { controlled machinery }\end{array}$ & percentage of computer-controlled machinery at the plant. \\
\hline & $\begin{array}{l}\text { Use of foreign } \\
\text { technology }\end{array}$ & $\begin{array}{l}\text { dummy variable }=1 \text { if the plant uses technology obtained from foreign } \\
\text { firms paying or not paying licenses for that use. }\end{array}$ \\
\hline & $\begin{array}{l}\text { Introduction of new } \\
\text { products }\end{array}$ & $\begin{array}{l}\text { dummy variable }=1 \text { if the plant introduced new products in the last } 3 \\
\text { years. }\end{array}$ \\
\hline & R\&D & Fraction of total staff engaged en R\&D activities \\
\hline & Training & $\begin{array}{l}\text { dummy variable }=1 \text { if the plant provides training to its employees other } \\
\text { than on the job }\end{array}$ \\
\hline & $\begin{array}{l}\text { Percentage of staff with } \\
\text { secondary education }\end{array}$ & $\begin{array}{l}\text { percentage of workers (including management) with at least secondary } \\
\text { education. }\end{array}$ \\
\hline & Domestic market share & how much the plant's sales represent out of total national market. \\
\hline & Exporter & dummy variable $=1$ if the plant exports at least $10 \%$ of its output. \\
\hline & Foreign ownership & dummy variable $=1$ if plant has any share of its capital that is foreign. \\
\hline & Age & $\begin{array}{l}\text { difference between } 2002 \text { and the year that the firm started operations in } \\
\text { the country. }\end{array}$ \\
\hline & Capacity utilization & percentage of capacity utilized \\
\hline & $\begin{array}{l}\text { Inverse number of } \\
\text { competitors }\end{array}$ & $1 /$ number of competitors of the plant. \\
\hline & Internet access & $\begin{array}{l}\text { dummy variable }=1 \text { if the plant has used email or a website in its } \\
\text { interactions with clients or suppliers. }\end{array}$ \\
\hline & ISO certification & Firm has ISO Quality certification \\
\hline & External audit & $\begin{array}{l}\text { Dummy variable }=1 \text { if the firm's annual financial statement is reviewed } \\
\text { by an external auditor }\end{array}$ \\
\hline & Share of imported inputs & Fraction of material inputs that are imported \\
\hline & Publicly Listed & Dummy variable $=1$ if the firm is publicly listed \\
\hline
\end{tabular}

Table A.4: Investment Climate - Perception (PE) Variables

\begin{tabular}{|c|c|c|}
\hline \multirow{4}{*}{ Infrastructure } & Electricity problem & $\begin{array}{l}\text { ranking by the plant of electricity as a problem for its operations and } \\
\text { growth. }\end{array}$ \\
\hline & Generator & dummy variable $=1$ if the plant has a generator. \\
\hline & Customs problem & $\begin{array}{l}\text { ranking by the plant of customs as a problem for its operations and } \\
\text { growth. }\end{array}$ \\
\hline & Export experience & number of years since the plant first started exporting. \\
\hline \multirow{7}{*}{$\begin{array}{l}\text { Bureaucracy/ } \\
\text { Corruption }\end{array}$} & $\begin{array}{l}\text { Tax administration } \\
\text { problem }\end{array}$ & $\begin{array}{l}\text { ranking by the plant of tax administration as a problem for its operations } \\
\text { and growth. }\end{array}$ \\
\hline & $\begin{array}{l}\text { Trade regulation } \\
\text { problem }\end{array}$ & $\begin{array}{l}\text { ranking by the plant of trade regulation as a problem for its operations } \\
\text { and growth. }\end{array}$ \\
\hline & $\begin{array}{l}\text { Labor regulation } \\
\text { problem }\end{array}$ & $\begin{array}{l}\text { ranking by the plant of labor regulation as a problem for its operations } \\
\text { and growth. }\end{array}$ \\
\hline & Permit problem & $\begin{array}{l}\text { ranking by the plant of permit and business registration as a problem for } \\
\text { its operations and growth. }\end{array}$ \\
\hline & $\begin{array}{l}\text { Regulatory policy } \\
\text { uncertainty problem }\end{array}$ & $\begin{array}{l}\text { ranking by the plant of regulatory policy uncertainty as a problem for its } \\
\text { operations and growth. }\end{array}$ \\
\hline & $\begin{array}{l}\text { Government } \\
\text { inconsistency }\end{array}$ & $\begin{array}{l}\text { dummy variable }=1 \text { if the plant answered that the government is very } \\
\text { inconsistent or inconsistent in interpreting laws and regulations affecting } \\
\text { the plant. }\end{array}$ \\
\hline & Corruption problem & $\begin{array}{l}\text { ranking by the plant of corruption a problem for its operations and } \\
\text { growth. }\end{array}$ \\
\hline \multirow{2}{*}{ Crime } & Crime problem & ranking by the plant of crime a problem for its operations and growth. \\
\hline & Security cost & Expenditure on security related items by the plant as percentage of sales. \\
\hline \multirow{3}{*}{ Finance } & $\begin{array}{l}\text { Finance availability } \\
\text { problem }\end{array}$ & $\begin{array}{l}\text { ranking by the plant of availability of finance as a problem for its } \\
\text { operations and growth. }\end{array}$ \\
\hline & Cost of finance problem & $\begin{array}{l}\text { ranking by the plant of cost of finance as a problem for its operations and } \\
\text { growth. }\end{array}$ \\
\hline & Finance access problem & $\begin{array}{l}\text { ranking by the plant of access to finance as a problem for its operations } \\
\text { and growth. }\end{array}$ \\
\hline
\end{tabular}


Table B.1: Number of Firms that Enter into the IC Regressions by Industry and by Country

\begin{tabular}{|l|l|l|l|l|}
\hline Industry & Guatemala & Honduras & Nicaragua & Total \\
\hline Apparel & 129 & 70 & 64 & 263 \\
\hline Beverages & 8 & 19 & 17 & 44 \\
\hline Chemical/Rubber & 61 & 35 & 67 & 163 \\
\hline Food/ Tobacco & 102 & 134 & 68 & 304 \\
\hline Furniture/ Wood & 56 & 126 & 127 & 309 \\
\hline Leather/ Shoes & 6 & 0 & 45 & 51 \\
\hline $\begin{array}{l}\text { Nonmetallic } \\
\text { Minerals }\end{array}$ & 36 & 44 & 69 & 149 \\
\hline Textiles & 22 & 9 & 7 & 38 \\
\hline Metal Products & 48 & 35 & 57 & 140 \\
\hline Total & 468 & 472 & 521 & 1,461 \\
\hline
\end{tabular}

Table B.2: Number of Firms that Enter into the IC Regressions by Industry and by Year

\begin{tabular}{|l|l|l|l|}
\hline Industry & $\mathbf{2 0 0 1}$ & $\mathbf{2 0 0 2}$ & Total \\
\hline Apparel & 71 & 191 & 263 \\
\hline Beverages & 12 & 32 & 44 \\
\hline Chemical/Rubber & 52 & 111 & 163 \\
\hline Food/ Tobacco & 103 & 201 & 304 \\
\hline Furniture/ Wood & 90 & 219 & 309 \\
\hline Leather/ Shoes & 15 & 36 & 51 \\
\hline Nonmetallic Minerals & 44 & 105 & 149 \\
\hline Textiles & 8 & 30 & 38 \\
\hline Metal Products & 45 & 95 & 140 \\
\hline Total & 441 & 1,020 & 1,461 \\
\hline
\end{tabular}


Table B.3: List of Significant ICA Variables and their Measurement Units

\begin{tabular}{|c|c|}
\hline Explanatory ICA Variables & Measurement Units \\
\hline Average duration of power outages & Hours per day (in logs) \\
\hline Average number of days to clear customs for imports & Days (in logs) \\
\hline Shipment Losses & Fraction of total sales (per unit) \\
\hline Dummy for Internet Access & 0 or 1 \\
\hline $\begin{array}{l}\text { Number of days spent in Inspection and Regulation } \\
\text { related work }\end{array}$ & Days \\
\hline Fraction of sales declared to IRS for tax purposes & Fraction of Total Sales (per unit) \\
\hline $\begin{array}{l}\text { Payments to deal with bureaucracy"faster" as a } \% \text { of } \\
\text { sales }\end{array}$ & Percentage of total sales (per 100) \\
\hline Number of criminal attempts suffered & Numbers \\
\hline Fraction of computer-controlled machinery & Fraction of total machinery (per unit) \\
\hline Fraction of total staff engaged in R \& D & Fraction of total staff (per unit) \\
\hline Dummy for ISO quality certification & 0 or 1 \\
\hline $\begin{array}{l}\text { Fraction of total staff with secondary education or } \\
\text { more }\end{array}$ & Fraction of total staff ( per unit) \\
\hline $\begin{array}{l}\text { Dummy for Training provided beyond "on the job" } \\
\text { training }\end{array}$ & 0 or 1 \\
\hline Dummy for Incorporated Company & 0 or 1 \\
\hline Dummy for external audit of Financial statements & 0 or 1 \\
\hline Age of the firm & Age in years (in logs) \\
\hline Share of Imported inputs & Fraction of total inputs( per unit) \\
\hline
\end{tabular}

* In all the regressions, outlier plants were excluded. Outlier plants were defined as those which had ratios of materials to sales larger than one or had ratios of labor costs to sales larger than one. 
Table C.1: Correlation between Solow Residuals in Levels and Estimated Productivity

\begin{tabular}{|l|l|l|l|l|}
\hline \multirow{2}{*}{} & & \multicolumn{3}{|c|}{ Solow Residuals } \\
\cline { 3 - 5 } & & Restricted & $\begin{array}{l}\text { Unrestricted } \\
\text { by } \\
\text { Industry }\end{array}$ \\
\hline \multirow{4}{*}{$\begin{array}{l}\text { Estimated } \\
\text { Productivity }\end{array}$} & \multirow{2}{*}{ Cobb Douglas } & OLS & 0.99 & 0.81 \\
\cline { 3 - 5 } & Random Effect & 0.98 & 0.74 \\
\cline { 2 - 5 } & \multirow{2}{*}{ Translog } & OLS & 0.86 & 0.27 \\
\cline { 3 - 5 } & & Random Effect & 0.83 & 0.23 \\
\hline
\end{tabular}

Notes:

a) Solow residuals in levels are obtained as sales (in logarithms or logs) minus a weighted average of labor, materials, capital (all in logs) where the weights are given by the share in total costs of each of the inputs. The cost of capital is assumed to be equal to $10 \%$ times the capital stock.

(1) Restricted case: the cost shares are calculated as the averages of the plant-level cost shares across the entire sample of three countries in 2002 and 2001.

(2) Unrestricted by Industry case: the cost shares are calculated as the averages across plant-level cost shares in years 2002 and 2001 for each of nine industries (for each industry all plants of the three countries that are not outliers are considered).

(3) Outlier plants were defined as those which had ratios of materials to sales larger than one or had ratios of labor costs to sales larger than one.

b) Estimated Productivity in levels is obtained from Cobb-Douglas and Translog production functions of sales with inputs labor, materials, and capital estimated by OLS and random effects under two different environments:

(1) Restricted: a single set of production function coefficients is obtained using data on plants in the three countries, for all industries in years 2002 and 2001.

(2) Unrestricted by Industry: a set of production function coefficients is obtained for each of nine industries using data on all plants for the three countries in years 2002 and 2001 (excluding outliers). 
Table C.2: Two-Step Restricted Estimation

Dependent Variable: Restricted Solow Residual in Levels (logs)

\begin{tabular}{|c|c|c|c|}
\hline & & OLS & Random Effects \\
\hline \multirow{6}{*}{$\begin{array}{l}\text { Red Tape, Corruption } \\
\text { and Crime }\end{array}$} & $\begin{array}{l}\text { Number of days spent in Inspection and Regulation related } \\
\text { work }\end{array}$ & {$\left[\begin{array}{l}-0.097^{\star \star} \\
{[0.043]}\end{array}\right.$} & $\begin{array}{l}-0.091^{*} \\
{[0.048]}\end{array}$ \\
\hline & $\begin{array}{l}\text { Fraction of sales undeclared to the tax authority for tax } \\
\text { purposes }\end{array}$ & $\begin{array}{l}-0.601^{\star *} \\
{[0.263]}\end{array}$ & $\begin{array}{l}-0.613^{* *} \\
{[0.266]}\end{array}$ \\
\hline & \multirow[t]{2}{*}{ Payments to deal with bureaucracy "faster", percent of sales } & $0.031^{* *}$ & $0.029 * *$ \\
\hline & & {$[0.012]$} & {$[0.013]$} \\
\hline & \multirow{2}{*}{ Number of criminal attempts suffered } & $-0.029^{\star \star}$ & $-0.033^{\star \star}$ \\
\hline & & {$[0.012]$} & {$[0.014]$} \\
\hline \multirow{8}{*}{ Infrastructure } & \multirow{2}{*}{ Average duration of power outages $(\log )$} & $-0.095^{\star}$ & -0.077 \\
\hline & & {$[0.052]$} & {$[0.062]$} \\
\hline & \multirow{2}{*}{ Days to clear customs for imports (log) } & $-0.097^{\star *}$ & $-0.098^{* *}$ \\
\hline & & {$[0.041]$} & {$[0.041]$} \\
\hline & \multirow{2}{*}{ Shipment Losses (fraction of Sales) } & $-1.860 * \star$ & -1.348 \\
\hline & & {$[0.850]$} & {$[1.341]$} \\
\hline & \multirow{2}{*}{ Dummy for Internet Access } & $0.147^{\star \star \star}$ & $0.136^{\star \star \star}$ \\
\hline & & {$[0.038]$} & {$[0.042]$} \\
\hline \multirow{10}{*}{$\begin{array}{l}\text { Quality, Innovation and } \\
\text { Labor Skills }\end{array}$} & \multirow{2}{*}{ Fraction of computer-controlled machinery } & 0.119 & 0.153 \\
\hline & & {$[0.082]$} & {$[0.097]$} \\
\hline & \multirow{2}{*}{ Fraction of total staff engaged in $R \& D$} & $0.594^{\star \star}$ & $0.535^{\star}$ \\
\hline & & {$[0.287]$} & {$[0.284]$} \\
\hline & \multirow{2}{*}{ Dummy for ISO quality certification } & 0.154 & $0.184^{\star \star}$ \\
\hline & & {$[0.102]$} & {$[0.090]$} \\
\hline & \multirow{2}{*}{ Fraction of total staff with secondary education or higher } & 0.036 & 0.066 \\
\hline & & {$[0.058]$} & {$[0.060]$} \\
\hline & \multirow{2}{*}{ Dummy for Training provided beyond "on the job" training } & $0.117^{\star \star \star}$ & $0.115^{\star \star \star}$ \\
\hline & & {$[0.036]$} & {$[0.038]$} \\
\hline \multirow{4}{*}{$\begin{array}{l}\text { Finance and Corporate } \\
\text { Governance }\end{array}$} & \multirow{2}{*}{ Dummy for Incorporated Company } & $0.150^{\star \star \star}$ & 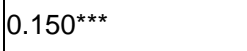 \\
\hline & & {$[0.039]$} & {$[0.042]$} \\
\hline & \multirow{2}{*}{ Dummy for external audit of Financial statements } & $0.168^{\star \star \star}$ & $0.159 * \star \star$ \\
\hline & & {$[0.042]$} & {$[0.040]$} \\
\hline \multirow{8}{*}{ Others Control Variables } & \multirow{2}{*}{ Age of the firm $(\log )$} & $0.050^{\star *}$ & $0.051^{\star *}$ \\
\hline & & {$[0.020]$} & {$[0.022]$} \\
\hline & \multirow{2}{*}{ Share of Imported inputs (fraction) } & $0.113^{\star \star}$ & $0.115^{\star \star}$ \\
\hline & & {$[0.049]$} & {$[0.052]$} \\
\hline & Observations & 1461 & 1461 \\
\hline & R-squared & 0.2 & 0.2 \\
\hline & \multirow{2}{*}{$\begin{array}{l}\text { Test of joint significance } \\
\text { of IC Variables } \\
\text { Test of joint significance } \\
\text { of ICVs and Plant level controls }\end{array}$} & Prob $>F=0.0000$ & Prob $>$ chi $2=0.0002$ \\
\hline & & Prob $>F=0.0000$ & Prob $>$ chi $2=0.0000$ \\
\hline
\end{tabular}

Notes:

(1) Significance is given by robust standard errors. * significant at 10\%; ** significant at 5\%; *** significant at $1 \%$.

(2) The restricted Solow Residual is obtained using cost shares for inputs (labor, materials and capital) calculated as averages across all plants in the three countries in years 2001 and 2002 (excluding outliers).

(3) The regressions include a constant, industry dummies, country dummies and year dummies. 


\section{Table C.3.1: Single Step Restricted Estimation: Cobb Douglas Specification}

Dependent Variable: Productivity in Levels (in logs)

\begin{tabular}{|c|c|c|c|}
\hline & & OLS & Random Effects \\
\hline \multirow[t]{8}{*}{$\begin{array}{l}\text { Red Tape, Corruption and } \\
\text { Crime }\end{array}$} & \multirow[t]{2}{*}{$\begin{array}{l}\text { Number of days spent in Inspection and } \\
\text { Regulation related work }\end{array}$} & $-0.099 * *$ & -0.077 \\
\hline & & {$[0.043]$} & {$[0.053]$} \\
\hline & \multirow[t]{2}{*}{$\begin{array}{l}\text { Fraction of sales undeclared to the tax } \\
\text { authority for tax purposes }\end{array}$} & $-0.612 * *$ & $-0.672 * *$ \\
\hline & & {$[0.260]$} & {$[0.295]$} \\
\hline & \multirow[t]{2}{*}{$\begin{array}{l}\text { Payments to deal with bureaucracy } \\
\text { "faster", percent of sales }\end{array}$} & $0.033 * * *$ & $0.029^{* *}$ \\
\hline & & {$[0.012]$} & {$[0.014]$} \\
\hline & \multirow[t]{2}{*}{ Number of criminal attempts suffered } & $-0.031 * * *$ & $-0.039 * *$ \\
\hline & & {$[0.012]$} & {$[0.016]$} \\
\hline \multirow[t]{8}{*}{ Infrastructure } & \multirow[t]{2}{*}{ Average duration of power outages $(\log )$} & $-0.085^{*}$ & -0.077 \\
\hline & & {$[0.050]$} & {$[0.069]$} \\
\hline & \multirow[t]{2}{*}{ Days to clear customs for imports (log) } & $-0.106^{* *}$ & $-0.111 * *$ \\
\hline & & [0.042] & [0.045] \\
\hline & \multirow[t]{2}{*}{ Shipment Losses (fraction of Sales) } & $-2.119 * *$ & -1.082 \\
\hline & & {$[0.867]$} & [1.483] \\
\hline & \multirow[t]{2}{*}{ Dummy for Internet Access } & $0.144 * * *$ & $0.180 * * *$ \\
\hline & & [0.041] & {$[0.048]$} \\
\hline \multirow[t]{10}{*}{$\begin{array}{l}\text { Quality, Innovation and } \\
\text { Labor Skills }\end{array}$} & \multirow[t]{2}{*}{$\begin{array}{l}\text { Fraction of computer-controlled } \\
\text { machinery }\end{array}$} & 0.13 & $0.204^{*}$ \\
\hline & & {$[0.082]$} & {$[0.107]$} \\
\hline & \multirow[t]{2}{*}{ Fraction of total staff engaged in $R \& D$} & $0.667^{* *}$ & $0.627^{* *}$ \\
\hline & & {$[0.294]$} & {$[0.316]$} \\
\hline & \multirow[t]{2}{*}{ Dummy for ISO quality certification } & 0.167 & $0.209^{* *}$ \\
\hline & & {$[0.103]$} & {$[0.101]$} \\
\hline & \multirow[t]{2}{*}{$\begin{array}{l}\text { Fraction of total staff with secondary } \\
\text { education or higher }\end{array}$} & 0.048 & 0.096 \\
\hline & & {$[0.059]$} & {$[0.067]$} \\
\hline & \multirow[t]{2}{*}{$\begin{array}{l}\text { Dummy for Training provided beyond } \\
\text { "on the job" training }\end{array}$} & $0.105 * * *$ & $0.139 * * *$ \\
\hline & & {$[0.036]$} & [0.043] \\
\hline \multirow{4}{*}{$\begin{array}{l}\text { Finance and Corporate } \\
\text { Governance }\end{array}$} & \multirow{2}{*}{ Dummy for Incorporated Company } & $0.140 * * *$ & $0.169 * * *$ \\
\hline & & {$[0.042]$} & {$[0.048]$} \\
\hline & \multirow[t]{2}{*}{$\begin{array}{l}\text { Dummy for external audit of Financial } \\
\text { statements }\end{array}$} & $0.159 * * *$ & $0.185 * * *$ \\
\hline & & {$[0.042]$} & {$[0.046]$} \\
\hline \multirow[t]{10}{*}{ Others Control Variables } & \multirow[t]{2}{*}{ Age of the firm $(\log )$} & $0.049 * *$ & $0.057 * *$ \\
\hline & & {$[0.020]$} & {$[0.024]$} \\
\hline & \multirow[t]{2}{*}{ Share of Imported inputs (fraction) } & $0.101 * *$ & $0.142 * *$ \\
\hline & & {$[0.051]$} & {$[0.058]$} \\
\hline & Observations & 1461 & 1461 \\
\hline & R-squared & 0.2 & 0.26 \\
\hline & Test of joint significance & Prob $>F=0.000$ & Prob $>$ chi $2=0.0005$ \\
\hline & of IC Variables & & \\
\hline & Test of joint significance & Prob $>F=0.000$ & Prob $>$ chi $2=0.0000$ \\
\hline & of ICVs and Plant level controls & & \\
\hline
\end{tabular}

Notes:

(1) Significance is given by robust standard errors. * significant at 10\%; ** significant at 5\%; *** significant at $1 \%$.

(2) The dependent variable Productivity is computed as the difference between sales and inputs multiplied by the corresponding Cobb-Douglas production function coefficients in Table C 3.3. A single regression of sales on inputs and the variables above is estimated that includes a constant, industry dummies, country dummies and year dummies.

(3) The regressions include a constant, industry dummies, country dummies and year dummies. 
Table C.3.2: Single-Step Restricted Estimation: Translog Specification

Dependent Variable: Productivity in Levels (logs)

\begin{tabular}{|c|c|c|c|}
\hline & & OLS & Random Effects \\
\hline \multirow[t]{8}{*}{$\begin{array}{l}\text { Red Tape, Corruption and } \\
\text { Crime }\end{array}$} & \multirow[t]{2}{*}{$\begin{array}{l}\text { Number of days spent in Inspection and } \\
\text { Regulation related work }\end{array}$} & -0.058 & -0.054 \\
\hline & & {$[0.041]$} & {$[0.049]$} \\
\hline & \multirow[t]{2}{*}{$\begin{array}{l}\text { Fraction of sales undeclared to the tax } \\
\text { authority for tax purposes }\end{array}$} & $-0.416^{*}$ & $-0.521^{*}$ \\
\hline & & {$[0.243]$} & {$[0.277]$} \\
\hline & \multirow[t]{2}{*}{$\begin{array}{l}\text { Payments to deal with bureaucracy "faster", } \\
\text { percent of sales }\end{array}$} & 0.015 & 0.013 \\
\hline & & {$[0.012]$} & {$[0.014]$} \\
\hline & \multirow[t]{2}{*}{ Number of criminal attempts suffered } & \begin{tabular}{|l|}
-0.018 \\
\end{tabular} & $-0.027^{*}$ \\
\hline & & {$[0.011]$} & {$[0.015]$} \\
\hline \multirow[t]{8}{*}{ Infrastructure } & \multirow[t]{2}{*}{ Average duration of power outages $(\log )$} & -0.072 & -0.057 \\
\hline & & {$[0.047]$} & {$[0.064]$} \\
\hline & \multirow[t]{2}{*}{ Days to clear customs for imports (log) } & $-0.125^{\star \star \star}$ & $-0.136^{\star \star \star}$ \\
\hline & & {$[0.039]$} & {$[0.042]$} \\
\hline & \multirow[t]{2}{*}{ Shipment Losses (fraction of Sales) } & -1.229 & -0.355 \\
\hline & & {$[0.811]$} & {$[1.391]$} \\
\hline & \multirow[t]{2}{*}{ Dummy for Internet Access } & $0.119^{\star \star \star}$ & $0.158^{\star \star \star}$ \\
\hline & & {$[0.039]$} & {$[0.046]$} \\
\hline \multirow{10}{*}{$\begin{array}{l}\text { Quality, Innovation and Labor } \\
\text { Skills }\end{array}$} & \multirow{2}{*}{ Fraction of computer-controlled machinery } & $0.132^{*}$ & $0.169^{*}$ \\
\hline & & {$[0.079]$} & {$[0.101]$} \\
\hline & \multirow[t]{2}{*}{ Fraction of total staff engaged in $R \& D$} & $0.581^{\star \star}$ & $0.633^{\star \star}$ \\
\hline & & {$[0.270]$} & {$[0.297]$} \\
\hline & \multirow[t]{2}{*}{ Dummy for ISO quality certification } & 0.024 & 0.066 \\
\hline & & {$[0.093]$} & [0.095] \\
\hline & \multirow{2}{*}{$\begin{array}{l}\text { Fraction of total staff with secondary education } \\
\text { or higher }\end{array}$} & 0.03 & 0.075 \\
\hline & & {$[0.059]$} & {$[0.063]$} \\
\hline & \multirow[t]{2}{*}{$\begin{array}{l}\text { Dummy for Training provided beyond "on the } \\
\text { job" training }\end{array}$} & $0.089^{\star \star \star}$ & $0.117^{\star \star \star}$ \\
\hline & & {$[0.033]$} & {$[0.041]$} \\
\hline \multirow{4}{*}{ 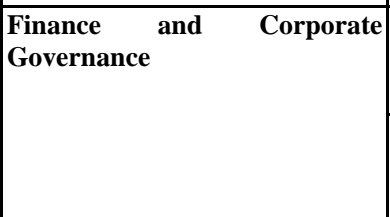 } & \multirow{2}{*}{ Dummy for Incorporated Company } & $0.115^{\star \star \star}$ & $0.143^{\star \star \star}$ \\
\hline & & {$[0.038]$} & {$[0.046]$} \\
\hline & \multirow[t]{2}{*}{\begin{tabular}{|l} 
Dummy for external audit of Financial \\
statements
\end{tabular}} & $0.121^{\star \star \star}$ & 0.139 *** \\
\hline & & {$[0.038]$} & {$[0.043]$} \\
\hline \multirow[t]{10}{*}{ Others Control Variables } & \multirow[t]{2}{*}{ Age of the firm $(\log )$} & $0.046^{* \star}$ & $0.052^{\star \star}$ \\
\hline & & {$[0.018]$} & {$[0.022]$} \\
\hline & \multirow[t]{2}{*}{ Share of Imported inputs (fraction) } & $0.096^{\star \star}$ & $0.131^{\star \star}$ \\
\hline & & {$[0.047]$} & {$[0.055]$} \\
\hline & Observations & 1461 & 1461 \\
\hline & R-squared & 0.36 & 0.36 \\
\hline & Test of joint significance & Prob $>F=0.0027$ & Prob $>$ chi $2=0.0051$ \\
\hline & of IC Variables & & \\
\hline & Test of joint significance & Prob $>F=0.0000$ & Prob $>$ chi2 $=0.0000$ \\
\hline & of ICVs and Plant level controls & & \\
\hline
\end{tabular}

Notes:

(1) Significance is given by robust standard errors. * significant at $10 \%$; ** significant at $5 \%$; ** significant at $1 \%$.

(2) The dependent variable, Productivity in levels, is computed as the difference between log sales and log inputs multiplied by the corresponding Translog production function coefficients in Table 3.3. The Single Step regression indicates that all of the parameters of the Translog specification from Table 3.2 and Table 3.3 are jointly estimated in the same regression since the explanatory variables are correlated. 


\section{Table C.3.3: Production Function Parameters from the Restricted Estimation}

\begin{tabular}{|c|c|c|c|c|c|c|c|c|c|}
\hline & Labor(L) & $\begin{array}{l}\text { Material } \\
\text { Input(M) }\end{array}$ & Capital(K) & $\mathbf{L}^{2}$ & $\mathbf{M}^{2}$ & $\mathbf{K}^{2}$ & $\mathbf{L} * \mathbf{M}$ & $\mathbf{L} * \mathbf{K}$ & $\mathbf{M} * \mathbf{K}$ \\
\hline Cost Shares & 0.36 & 0.53 & 0.11 & - & - & - & - & - & - \\
\hline \multicolumn{10}{|c|}{ COBB DOUGLAS } \\
\hline OLS & $0.423 * * *$ & $0.537 * * *$ & $0.060 * * *$ & - & - & - & - & - & - \\
\hline $\begin{array}{l}\text { Random } \\
\text { Effects }\end{array}$ & $0.489 * * *$ & $0.448 * * *$ & $0.065 * * *$ & - & - & - & - & - & - \\
\hline \multicolumn{4}{|c|}{ Test for Constant Returns to Scale } & OLS & \multicolumn{2}{|c|}{ Prob $>F=0.000$} & R.E. & \multicolumn{2}{|c|}{ Prob $>$ chi $=0.0006$} \\
\hline \multicolumn{10}{|l|}{ TRANSLOG } \\
\hline OLS & $1.329 * * *$ & -0.11 & -0.009 & $0.070 * * *$ & $0.067 * * *$ & $0.017 * *$ & $-0.141 * * *$ & 0.016 & $-0.032 * *$ \\
\hline $\begin{array}{l}\text { Random } \\
\text { Effects }\end{array}$ & $1.545 * * *$ & $-0.315 * * *$ & $-0.164 * *$ & $0.064 * * *$ & $0.053 * * *$ & $0.012 * *$ & $-0.121 * * *$ & -0.014 & 0.001 \\
\hline \multicolumn{4}{|c|}{ Test for Cobb Douglas } & OLS & \multicolumn{2}{|c|}{ Prob $>F=0.000$} & R.E. & \multicolumn{2}{|c|}{ Prob $>$ chi $2=0.000$} \\
\hline \multicolumn{4}{|c|}{ Test for Constant Returns to Scale } & OLS & \multicolumn{2}{|c|}{ Prob $>F=0.000$} & R.E. & \multicolumn{2}{|c|}{ Prob $>$ chi $2=0.000$} \\
\hline
\end{tabular}

Notes:

(1) Significance is given by robust standard errors.* significant at $10 \% ; * *$ significant at $5 \%$; *** significant at $1 \%$.

(2) The cost shares of labor, materials and capital are calculated as averages of the plant-level cost shares of labor, materials and capital across all plants for the 3 countries in years 2002 and 2001 (excluding outliers).

(3) The sample generating the sets of production function coefficients is constituted by all plants in the 3 countries in years 2002 and 2001 (excluding outliers).

(4) 0 indicates that the coefficient for that input in that industry is not significant and hence, is restricted to be equal to 0 . 


\section{Econometric Methodologies for Investment Climate Assessments on Productivity}

Table C.4.1: Two-Step Unrestricted By Industry Estimation

Dependent Variable: Solow Residuals by Industry in levels (logs)

\begin{tabular}{|c|c|c|c|}
\hline & & OLS & Random Effects \\
\hline \multirow[t]{8}{*}{$\begin{array}{l}\text { Red Tape, Corruption } \\
\text { and Crime }\end{array}$} & \multirow[t]{2}{*}{\begin{tabular}{|l} 
Number of days spent in Inspection and \\
Regulation related work
\end{tabular}} & $-0.101^{\star \star}$ & $-0.095^{\star \star}$ \\
\hline & & {$[0.043]$} & {$[0.047]$} \\
\hline & \multirow[t]{2}{*}{$\begin{array}{l}\text { Fraction of sales undeclared to the tax authority } \\
\text { for tax purposes }\end{array}$} & $-0.676^{\star \star}$ & $-0.678^{\star \star}$ \\
\hline & & {$[0.267]$} & {$[0.266]$} \\
\hline & \multirow[t]{2}{*}{$\begin{array}{l}\begin{array}{l}\text { Payments to deal with bureaucracy "faster", } \\
\text { percent of sales }\end{array} \\
\end{array}$} & $0.031^{\star *}$ & $0.029^{\star \star}$ \\
\hline & & {$[0.012]$} & {$[0.013]$} \\
\hline & \multirow[t]{2}{*}{ Number of criminal attempts suffered } & $-0.032^{\star \star \star}$ & $-0.035^{\star \star}$ \\
\hline & & {$[0.012]$} & {$[0.014]$} \\
\hline \multirow{8}{*}{ Infrastructure } & \multirow{2}{*}{ Average duration of power outages $(\log )$} & $-0.088^{*}$ & -0.07 \\
\hline & & {$[0.052]$} & {$[0.062]$} \\
\hline & \multirow[t]{2}{*}{ Days to clear customs for imports $(\log )$} & $-0.105^{\star \star \star}$ & $-0.106^{\star \star \star}$ \\
\hline & & {$[0.041]$} & {$[0.041]$} \\
\hline & \multirow[t]{2}{*}{ Shipment Losses (fraction of Sales) } & $-1.948^{\star \star}$ & -1.436 \\
\hline & & {$[0.852]$} & [1.339] \\
\hline & \multirow[t]{2}{*}{ Dummy for Internet Access } & $0.139 * \star \star$ & $0.128^{\star \star \star}$ \\
\hline & & {$[0.038]$} & {$[0.042]$} \\
\hline \multirow{10}{*}{$\begin{array}{l}\text { Quality, Innovation and } \\
\text { Labor Skills }\end{array}$} & \multirow{2}{*}{ Fraction of computer-controlled machinery } & 0.117 & 0.15 \\
\hline & & {$[0.083]$} & {$[0.097]$} \\
\hline & \multirow[t]{2}{*}{ Fraction of total staff engaged in $\mathrm{R} \& \mathrm{D}$} & $0.589^{\star \star}$ & $0.526^{*}$ \\
\hline & & {$[0.285]$} & {$[0.283]$} \\
\hline & \multirow[t]{2}{*}{ Dummy for ISO quality certification } & 0.142 & $0.174^{*}$ \\
\hline & & {$[0.101]$} & {$[0.090]$} \\
\hline & \multirow{2}{*}{$\begin{array}{l}\text { Fraction of total staff with secondary education or } \\
\text { higher }\end{array}$} & 0.033 & 0.064 \\
\hline & & {$[0.057]$} & {$[0.060]$} \\
\hline & \multirow{2}{*}{$\begin{array}{l}\begin{array}{l}\text { Dummy for Training provided beyond "on the job" } \\
\text { training }\end{array} \\
\end{array}$} & $0.116^{\star \star \star}$ & $0.114^{\star \star \star}$ \\
\hline & & {$[0.036]$} & {$[0.038]$} \\
\hline \multirow{4}{*}{$\begin{array}{l}\text { Finance and Corporate } \\
\text { Governance }\end{array}$} & \multirow{2}{*}{ Dummy for Incorporated Company } & $0.146^{\star \star \star}$ & $0.146^{\star \star \star}$ \\
\hline & & {$[0.039]$} & [0.042] \\
\hline & \multirow[t]{2}{*}{ Dummy for external audit of Financial statements } & $0.170^{\star \star \star}$ & $0.160^{\star \star \star}$ \\
\hline & & {$[0.042]$} & {$[0.040]$} \\
\hline \multirow{8}{*}{\begin{tabular}{|l|} 
Others \\
Variables
\end{tabular}} & \multirow[t]{2}{*}{ Age of the firm $(\log )$} & 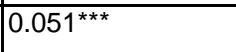 & $0.052^{\star \star}$ \\
\hline & & {$[0.020]$} & {$[0.022]$} \\
\hline & \multirow[t]{2}{*}{ Share of Imported inputs (fraction) } & $0.110^{\star \star}$ & $0.114^{\star \star}$ \\
\hline & & {$[0.049]$} & {$[0.052]$} \\
\hline & Observations & 1461 & 1461 \\
\hline & R-squared & 0.26 & 0.26 \\
\hline & Test of joint significance of IC Variables & Prob $>F=0.0000$ & Prob $>$ chi $2=0.0001$ \\
\hline & $\begin{array}{l}\text { Test of joint significance of ICVs and Plant level } \\
\text { controls }\end{array}$ & Prob $>F=0.0000$ & Prob $>$ chi $2=0.0000$ \\
\hline
\end{tabular}

Notes:

(1) Significance is given by robust standard errors. * significant at $10 \%$; * significant at 5\%; *** significant at $1 \%$.

(2) The unrestricted by industry Solow Residual is obtained using cost shares for inputs (labor, materials and capital) calculated as averages for each of the industries using plants for the 3 countries in years 2001 and 2002 .

(3) The regressions include a constant, industry dummies, country dummies and year dummies. 
Table C.4.2: Two-Step Unrestricted by Industry Estimation with Perception Variables

Dependent Variable: Solow Residuals by Industry in Levels (logs)

\begin{tabular}{|c|c|c|}
\hline & & OLS \\
\hline \multirow{8}{*}{$\begin{array}{l}\text { Red Tape, Corruption and } \\
\text { Crime }\end{array}$} & \multirow{2}{*}{ Number of days spent in Inspection and Regulation related work } & -0.063 \\
\hline & & {$[0.045]$} \\
\hline & \multirow[t]{2}{*}{ Fraction of sales undeclared to the tax authority for tax purposes } & $-0.505^{*}$ \\
\hline & & {$[0.277]$} \\
\hline & \multirow[t]{2}{*}{ Payments to deal with bureaucracy "faster", percent of sales } & $0.033 * * *$ \\
\hline & & {$[0.013]$} \\
\hline & \multirow[t]{2}{*}{ Number of criminal attempts suffered } & $-0.035^{* * *}$ \\
\hline & & {$[0.013]$} \\
\hline \multirow[t]{8}{*}{ Infrastructure } & \multirow[t]{2}{*}{ Average duration of power outages $(\log )$} & $-0.098^{*}$ \\
\hline & & {$[0.052]$} \\
\hline & \multirow[t]{2}{*}{ Days to clear customs for imports $(\log )$} & $-0.079 *$ \\
\hline & & {$[0.042]$} \\
\hline & \multirow[t]{2}{*}{ Shipment Losses (fraction of Sales) } & $-1.666^{* *}$ \\
\hline & & {$[0.830]$} \\
\hline & \multirow[t]{2}{*}{ Dummy for Internet Access } & $0.141 * * *$ \\
\hline & & {$[0.038]$} \\
\hline \multirow[t]{2}{*}{ Perceptions } & \multirow[t]{2}{*}{ Perception on Export experience } & $-0.020^{*}$ \\
\hline & & {$[0.011]$} \\
\hline \multirow{10}{*}{$\begin{array}{l}\text { Quality, Innovation and } \\
\text { Labor Skills }\end{array}$} & \multirow{2}{*}{ Fraction of computer-controlled machinery } & 0.117 \\
\hline & & {$[0.083]$} \\
\hline & \multirow[t]{2}{*}{ Fraction of total staff engaged in R\&D } & $0.570^{* *}$ \\
\hline & & {$[0.283]$} \\
\hline & \multirow[t]{2}{*}{ Dummy for ISO quality certification } & 0.14 \\
\hline & & {$[0.100]$} \\
\hline & \multirow[t]{2}{*}{ Fraction of total staff with secondary education or higher } & 0.048 \\
\hline & & {$[0.062]$} \\
\hline & \multirow[t]{2}{*}{ Dummy for Training provided beyond "on the job" training } & $0.113 * * *$ \\
\hline & & {$[0.035]$} \\
\hline \multirow{4}{*}{$\begin{array}{l}\text { Finance and Corporate } \\
\text { Governance }\end{array}$} & \multirow[t]{2}{*}{ Dummy for Incorporated Company } & $0.145 * * *$ \\
\hline & & {$[0.039]$} \\
\hline & \multirow[t]{2}{*}{ Dummy for external audit of Financial statements } & $0.165^{* * *}$ \\
\hline & & {$[0.042]$} \\
\hline \multirow[t]{10}{*}{ Others Control Variables } & \multirow[t]{2}{*}{ Age of the firm $(\log )$} & $0.053 * * *$ \\
\hline & & {$[0.020]$} \\
\hline & \multirow[t]{2}{*}{ Share of Imported inputs (fraction) } & $0.113^{* *}$ \\
\hline & & {$[0.049]$} \\
\hline & Observations & 1461 \\
\hline & R-squared & 0.26 \\
\hline & Test of joint significance & Prob $>F=0.0000$ \\
\hline & of IC Variables & \\
\hline & Test of joint significance & Prob $>F=0.0000$ \\
\hline & of ICVs and Plant level controls & \\
\hline
\end{tabular}

Notes:

(1) Significance is given by robust standard errors. * significant at $10 \%$; * significant at 5\%; *** significant at $1 \%$.

(2) The unrestricted by industry Solow residual TFP is obtained using cost shares for inputs (labor, materials and capital) calculated as averages for each of the industries using plants for the 3 countries in years 2001 and 2002.

(3) The regressions include a constant, industry dummies, country dummies and year dummies. 
Table C.5.1: Single-Step Unrestricted by Industry Estimation: Cobb Douglas Specification

Dependent Variable: Productivity in levels (logs)

\begin{tabular}{|c|c|c|c|}
\hline & & OLS & Random Effects \\
\hline \multirow[t]{8}{*}{$\begin{array}{l}\text { Red Tape, Corruption } \\
\text { and Crime }\end{array}$} & \multirow[t]{2}{*}{$\begin{array}{l}\text { Number of days spent in Inspection and Regulation } \\
\text { related work }\end{array}$} & $-0.107 * *$ & $-0.098^{*}$ \\
\hline & & {$[0.043]$} & {$[0.052]$} \\
\hline & \multirow[t]{2}{*}{$\begin{array}{l}\text { Fraction of sales undeclared to the tax authority for } \\
\text { tax purposes }\end{array}$} & $-0.767 * * *$ & $-0.825 * * *$ \\
\hline & & {$[0.255]$} & {$[0.296]$} \\
\hline & \multirow[t]{2}{*}{$\begin{array}{l}\text { Payments to deal with bureaucracy "faster", percent of } \\
\text { sales }\end{array}$} & $0.030^{* *}$ & $0.028^{*}$ \\
\hline & & {$[0.012]$} & {$[0.014]$} \\
\hline & \multirow[t]{2}{*}{ Number of criminal attempts suffered } & $-0.029 * *$ & $-0.032 * *$ \\
\hline & & {$[0.011]$} & {$[0.016]$} \\
\hline \multirow[t]{8}{*}{ Infrastructure } & \multirow[t]{2}{*}{ Average duration of power outages $(\log )$} & -0.075 & -0.06 \\
\hline & & {$[0.050]$} & {$[0.068]$} \\
\hline & \multirow[t]{2}{*}{ Days to clear customs for imports $(\log )$} & $-0.105 * *$ & $-0.112 * *$ \\
\hline & & {$[0.043]$} & {$[0.045]$} \\
\hline & \multirow[t]{2}{*}{ Shipment Losses (fraction of Sales) } & $-2.530 * * *$ & -1.832 \\
\hline & & {$[0.871]$} & {$[1.472]$} \\
\hline & \multirow[t]{2}{*}{ Dummy for Internet Access } & $0.128 * * *$ & $0.172 * * *$ \\
\hline & & {$[0.039]$} & {$[0.048]$} \\
\hline \multirow{10}{*}{$\begin{array}{l}\text { Quality, Innovation } \\
\text { and Labor Skills }\end{array}$} & \multirow{2}{*}{ Fraction of computer-controlled machinery } & 0.131 & $0.203 *$ \\
\hline & & {$[0.085]$} & {$[0.107]$} \\
\hline & \multirow[t]{2}{*}{ Fraction of total staff engaged in $R \& D$} & $0.607 * *$ & $0.556^{*}$ \\
\hline & & {$[0.280]$} & {$[0.313]$} \\
\hline & \multirow[t]{2}{*}{ Dummy for ISO quality certification } & $0.176^{*}$ & $0.204 * *$ \\
\hline & & {$[0.105]$} & {$[0.100]$} \\
\hline & \multirow[t]{2}{*}{$\begin{array}{l}\text { Fraction of total staff with secondary education or } \\
\text { higher }\end{array}$} & 0.054 & 0.105 \\
\hline & & {$[0.060]$} & {$[0.066]$} \\
\hline & \multirow[t]{2}{*}{$\begin{array}{l}\text { Dummy for Training provided beyond "on the job" } \\
\text { training }\end{array}$} & $0.110^{* * *}$ & $0.136^{* * *}$ \\
\hline & & {$[0.036]$} & {$[0.043]$} \\
\hline \multirow{4}{*}{$\begin{array}{l}\text { Finance and Corporate } \\
\text { Governance }\end{array}$} & \multirow{2}{*}{ Dummy for Incorporated Company } & $0.132 * * *$ & $0.144 * * *$ \\
\hline & & {$[0.040]$} & {$[0.048]$} \\
\hline & \multirow[t]{2}{*}{ Dummy for external audit of Financial statements } & $0.150 * * *$ & $0.175 * * *$ \\
\hline & & {$[0.042]$} & {$[0.046]$} \\
\hline \multirow{8}{*}{$\begin{array}{l}\text { Others } \\
\text { Variables }\end{array}$} & \multirow[t]{2}{*}{ Age of the firm $(\log )$} & $0.043^{* *}$ & $0.045^{*}$ \\
\hline & & {$[0.019]$} & {$[0.024]$} \\
\hline & \multirow[t]{2}{*}{ Share of Imported inputs (fraction) } & 0.074 & $0.111 *$ \\
\hline & & {$[0.051]$} & {$[0.059]$} \\
\hline & Observations & 1461 & 1461 \\
\hline & R-squared & 0.5 & 0.57 \\
\hline & Test of joint significance of IC Variables & Prob $>F=0.0001$ & Prob $>$ chi $2=0.0061$ \\
\hline & $\begin{array}{l}\text { Test of joint significance of ICVs and Plant level } \\
\text { controls }\end{array}$ & Prob $>\mathrm{F}=0.0000$ & Prob $>$ chi $2=0.0000$ \\
\hline
\end{tabular}

Notes:

(1) Significance is given by robust standard errors. * significant at $10 \%$;** significant at $5 \%$; *** significant at $1 \%$. (2) (2) The dependent variable, Productivity in levels, is computed as the difference between log sales and log inputs multiplied by the corresponding Cobb-Douglas production function coefficients in Table 5.3. The Single Step regression indicates that all the parameters of the Cobb-Douglas specification from Table 5.1 and Table 5.3 are jointly estimated in the same regression since the explanatory variables are correlated. 


\section{Table C.5.2: Single-Step Unrestricted by Industry Estimation: Translog Specification}

\section{Dependent Variable: Productivity in levels (logs)}

\begin{tabular}{|c|c|c|c|}
\hline & \multirow{3}{*}{$\begin{array}{l}\text { Number of days spent in Inspection and Regulation related } \\
\text { work }\end{array}$} & \multirow[b]{2}{*}{ OLS } & \multirow[b]{2}{*}{ Random Effects } \\
\hline & & & \\
\hline \multirow{4}{*}{$\begin{array}{l}\text { Red Tape, Corruption } \\
\text { and Crime }\end{array}$} & & {$\left[\begin{array}{l}0.068 * \\
{[0.041]}\end{array}\right.$} & {$\left[\begin{array}{l}-0.065 \\
{[0.050]}\end{array}\right.$} \\
\hline & $\begin{array}{l}\text { Fraction of sales undeclared to the tax authority for tax } \\
\text { purposes }\end{array}$ & $\begin{array}{l}-0.593 * * \\
{[0.250]}\end{array}$ & $\begin{array}{l}-0.620 * * \\
{[0.284]}\end{array}$ \\
\hline & Payments to deal with bureaucracy "faster", percent of sales & $\begin{array}{l}0.013 \\
{[0.012]}\end{array}$ & $\begin{array}{l}0.015 \\
{[0.014]}\end{array}$ \\
\hline & Number of criminal attempts suffered & $\begin{array}{l}-0.018 \\
{[0.012]}\end{array}$ & $\begin{array}{l}-0.022 \\
{[0.015]}\end{array}$ \\
\hline \multirow{4}{*}{ Infrastructure } & Average duration of power outages $(\log )$ & $\begin{array}{l}-0.024 \\
{[0.049]}\end{array}$ & {$\left[\begin{array}{l}-0.013 \\
{[0.066]}\end{array}\right.$} \\
\hline & Days to clear customs for imports (log) & $\begin{array}{l}-0.119 * * * \\
{[0.041]}\end{array}$ & $\begin{array}{l}-0.116^{* * *} \\
{[0.044]}\end{array}$ \\
\hline & Shipment Losses (fraction of Sales) & $\begin{array}{l}-2.063 * * \\
{[0.825]}\end{array}$ & $\begin{array}{l}-1.415 \\
{[1.398]}\end{array}$ \\
\hline & Dummy for Internet Access & $\begin{array}{l}0.111 * * * \\
{[0.037]}\end{array}$ & $\begin{array}{l}0.146 * * * \\
{[0.046]}\end{array}$ \\
\hline \multirow{5}{*}{$\begin{array}{l}\text { Quality, Innovation } \\
\text { and Labor Skills }\end{array}$} & Fraction of computer-controlled machinery & {$\left[\begin{array}{l}0.084 \\
{[0.086]}\end{array}\right]$} & $\begin{array}{l}0.124 \\
{[0.102]}\end{array}$ \\
\hline & Fraction of total staff engaged in R\&D & $\begin{array}{l}0.580 * * \\
{[0.268]}\end{array}$ & $\begin{array}{l}0.590 * * \\
{[0.297]}\end{array}$ \\
\hline & Dummy for ISO quality certification & $\begin{array}{l}0.105 \\
{[0.103]}\end{array}$ & {$\left[\begin{array}{l}0.101 \\
{[0.098]}\end{array}\right.$} \\
\hline & Fraction of total staff with secondary education or higher & $\left.\begin{array}{l}0.056 \\
{[0.062]}\end{array}\right]$ & {$\left[\begin{array}{l}0.101 * \\
{[0.063]}\end{array}\right]$} \\
\hline & Dummy for Training provided beyond "on the job" training & $\begin{array}{l}0.098 * * * \\
{[0.034]}\end{array}$ & $\begin{array}{l}0.120 * * * \\
{[0.041]}\end{array}$ \\
\hline \multirow{2}{*}{$\begin{array}{l}\text { Finance } \\
\text { Corporate } \\
\text { Governance }\end{array}$} & Dummy for Incorporated Company & $\begin{array}{l}0.117 * * * \\
{[0.038]}\end{array}$ & $\begin{array}{l}0.130 * * * \\
{[0.046]}\end{array}$ \\
\hline & Dummy for external audit of Financial statements & $\begin{array}{l}0.116 * * * \\
{[0.038]}\end{array}$ & $\begin{array}{l}0.131 * * * \\
{[0.044]}\end{array}$ \\
\hline \multirow{6}{*}{$\begin{array}{l}\text { Others } \\
\text { Variables }\end{array}$} & Age of the firm (log) & $\begin{array}{l}0.032 * \\
{[0.018]}\end{array}$ & $\left.\begin{array}{l}0.036 \\
{[0.023]}\end{array}\right]$ \\
\hline & Share of Imported inputs (fraction) & {$\left[\begin{array}{l}0.101^{* *} \\
{[0.048]}\end{array}\right.$} & $\begin{array}{l}0.117 * * \\
{[0.056]}\end{array}$ \\
\hline & $\begin{array}{l}\text { Observations } \\
\text { R-squared }\end{array}$ & $\begin{array}{l}1461 \\
0.94\end{array}$ & $\begin{array}{l}1461 \\
0.94\end{array}$ \\
\hline & $\begin{array}{l}\text { Test of joint significance } \\
\text { of IC Variables }\end{array}$ & Prob $>F=0.0083$ & Prob $>$ chi $2=0.0353$ \\
\hline & Test of joint significance & Prob $>F=0.0000$ & Prob $>$ chi $2=0.0000$ \\
\hline & of ICVs and Plant level controls & & \\
\hline
\end{tabular}

Notes:

(1) Significance is given by robust standard errors. * significant at 10\%; ** significant at 5\%; *** significant at $1 \%$.

(2) The dependent variable, Productivity in levels, is computed as the difference between log sales and log inputs multiplied by the corresponding Translog production function coefficients in Table 5.3. The Single Step regression indicates that all the parameters of the Translog specification from Table 5.2 and Table 5.3 are jointly estimated in the same regression since the explanatory variables are correlated. 


\section{Table C.5.3: Production Function Parameters from the Unrestricted Estimation by Industry: Cobb Douglas Specification}

INVESTMENT CLIMATE ASSESSMENT FOR GUATEMALA, HONDURAS AND NICARAGUA

\begin{tabular}{|c|c|c|c|c|c|}
\hline Industry & Coefficients & Labor(L) & $\begin{array}{l}\text { Material } \\
\text { Input (M) }\end{array}$ & Capital(K) & $\begin{array}{l}\text { Test for } \\
\text { Constant Returns } \\
\text { to Scale }\end{array}$ \\
\hline \multirow[t]{3}{*}{ Apparel } & Cost share & 0.41 & 0.49 & 0.10 & \\
\hline & OLS & $0.418 * * *$ & $0.478 * * *$ & $0.098 * * *$ & Prob $>F=0.8959$ \\
\hline & Random Effects & $0.403 * * *$ & $0.463 * * *$ & $0.081 * * *$ & Prob $>$ chi $2=0.0846$ \\
\hline \multirow[t]{3}{*}{ Beverages } & Cost share & 0.30 & 0.58 & 0.12 & \\
\hline & OLS & $0.595 * * *$ & $0.377 * * *$ & 0.094 & Prob $>F=0.5007$ \\
\hline & Random Effects & $0.563 * * *$ & $0.391 * * *$ & 0.085 & Prob $>$ chi $2=0.7420$ \\
\hline \multirow[t]{3}{*}{ Chemicals/Rubber } & Cost share & 0.33 & 0.59 & 0.08 & \\
\hline & OLS & $0.387 * * *$ & $0.597 * * *$ & $0.085 * *$ & Prob $>F=0.0179$ \\
\hline & Random Effects & $0.454 * * *$ & $0.523 * * *$ & $0.094 * *$ & Prob $>$ chi $2=0.1331$ \\
\hline \multirow[t]{3}{*}{ Food/ Tobacco } & Cost share & 0.35 & 0.55 & 0.11 & \\
\hline & OLS & $0.516 * * *$ & $0.517 * * *$ & 0.034 & Prob $>F=0.0051$ \\
\hline & Random Effects & $0.658 * * *$ & $0.366 * * *$ & $0.051 * *$ & Prob $>$ chi $2=0.0248$ \\
\hline \multirow[t]{3}{*}{ Furniture/Wood } & Cost share & 0.35 & 0.53 & 0.12 & \\
\hline & OLS & $0.327 * * *$ & $0.655 * * *$ & 0.019 & Prob $>F=0.9477$ \\
\hline & Random Effects & $0.396 * * *$ & $0.591 * * *$ & 0.022 & Prob $>$ chi $2=0.8243$ \\
\hline \multirow[t]{3}{*}{ Leather/ Shoes } & Cost share & 0.37 & 0.53 & 0.10 & \\
\hline & OLS & $0.866 * * *$ & $0.285^{*}$ & $0.084 * * *$ & Prob $>F=0.0467$ \\
\hline & Random Effects & $0.790 * * *$ & $0.286^{* *}$ & 0.092 & Prob $>$ chi $2=0.2020$ \\
\hline \multirow[t]{3}{*}{ Nonmetallic Minerals } & Cost share & 0.34 & 0.55 & 0.11 & \\
\hline & OLS & $0.346 * * *$ & $0.560 * * *$ & $0.103 * * *$ & Prob $>F=0.8921$ \\
\hline & Random Effects & $0.473 * * *$ & $0.436 * * *$ & $0.106 * *$ & Prob $>$ chi $2=0.8308$ \\
\hline \multirow[t]{3}{*}{ Textiles } & Cost share & 0.36 & 0.51 & 0.13 & \\
\hline & OLS & $0.361 * * *$ & $0.374 * * *$ & $0.218^{*}$ & Prob $>F=0.5458$ \\
\hline & Random Effects & $0.428 * * *$ & $0.310 * * *$ & $0.221 * *$ & Prob $>$ chi $2=0.6433$ \\
\hline \multirow[t]{3}{*}{ Metal Products } & Cost share & 0.38 & 0.51 & 0.11 & \\
\hline & OLS & $0.352 * * *$ & $0.567 * * *$ & 0.055 & Prob $>F=0.5050$ \\
\hline & Random Effects & $0.402 * * *$ & $0.506 * * *$ & 0.06 & Prob $>$ chi $2=0.5605$ \\
\hline
\end{tabular}

Notes:

(1) Significance is given by robust standard errors. * significant at $10 \%$; ** significant at 5\%; *** significant at $1 \%$.

(2) The cost shares of labor, materials and capital are calculated as averages of the plant-level cost shares of labor, materials and capital for each industry using all plants in the 3 countries for years 2002 and 2001 (excluding outliers). 


\section{Table C.5.4: Production Function Parameters from the Unrestricted by Industry Estimation: Translog Specification}

INVESTMENT CLIMATE ASSESSMENT FOR GUATEMALA, HONDURAS AND NICARAGUA

\begin{tabular}{|c|c|c|c|c|c|c|c|c|c|c|c|}
\hline & $\begin{array}{l}\text { Labor } \\
\text { (L) }\end{array}$ & $\begin{array}{l}\text { Material } \\
\text { Input } \\
\text { (M) }\end{array}$ & $\begin{array}{l}\text { Capital } \\
(\mathrm{K})\end{array}$ & L2 & M2 & K2 & $\mathbf{L}^{*} \mathbf{M}$ & $\mathbf{L}^{*} \mathbf{K}$ & $\mathbf{M}^{*} \mathbf{K}$ & $\begin{array}{l}\text { Test for } \\
\text { CD* } \\
\text { p values }\end{array}$ & $\begin{array}{l}\text { Test for } \\
\text { CRS } \\
\text { p values }\end{array}$ \\
\hline $\begin{array}{l}\text { Appar } \\
\text { OLS } \\
\text { R.E. }\end{array}$ & $\begin{array}{l}0.742 * * * \\
0.537 * *\end{array}$ & $\begin{array}{l}-0.306 \\
-0.234\end{array}$ & $\begin{array}{l}0.520 * * * \\
0.563 * * *\end{array}$ & $\begin{array}{l}0.051 * * \\
0.013\end{array}$ & $\begin{array}{l}0.126 * * * \\
0.120^{* * *}\end{array}$ & $\begin{array}{l}0.022^{*} \\
0.019^{*}\end{array}$ & $\begin{array}{l}- \\
0.177 * * * \\
- \\
0.151 * * * \\
\end{array}$ & $\begin{array}{l}0.106 * * * \\
0.123 * * *\end{array}$ & $\begin{array}{l}- \\
0.119 * * * \\
- \\
0.123 * * * \\
\end{array}$ & $\begin{array}{l}0.0000 \\
0.0000\end{array}$ & $\begin{array}{l}0.0000 \\
0.0000\end{array}$ \\
\hline $\begin{array}{l}\text { Bev. } \\
\text { OLS } \\
\text { R.E. }\end{array}$ & $\begin{array}{l}0.598 * * * \\
0.566 * * *\end{array}$ & $\begin{array}{l}0.378 * * * \\
0.391 * * *\end{array}$ & $\begin{array}{l}0.092 \\
0.091\end{array}$ & $\begin{array}{l}0 \\
0\end{array}$ & $\begin{array}{l}0 \\
0\end{array}$ & $\begin{array}{l}0 \\
0\end{array}$ & $\begin{array}{l}0 \\
0\end{array}$ & $\begin{array}{l}0 \\
0\end{array}$ & $\begin{array}{l}0 \\
0\end{array}$ & $\begin{array}{l}C D \\
C D\end{array}$ & $\begin{array}{l}0.3602 \\
0.5588\end{array}$ \\
\hline $\begin{array}{l}\text { Chem. } \\
\text { OLS } \\
\text { R.E. }\end{array}$ & $\begin{array}{l}1.278 * * * \\
1.177 * * *\end{array}$ & $\begin{array}{l}0.316 \\
0.370^{*}\end{array}$ & $\begin{array}{l}0.057 \\
0.069 *\end{array}$ & $\begin{array}{l}0.268 * * * \\
0.265 * * *\end{array}$ & $\begin{array}{l}0.069^{* * *} \\
0.056 * *\end{array}$ & $\begin{array}{l}0 \\
0\end{array}$ & $\begin{array}{l}- \\
0.152 * * * \\
- \\
0.139 * * *\end{array}$ & 0 & $\begin{array}{l}0 \\
0\end{array}$ & $\begin{array}{l}0.0001 \\
0.0214\end{array}$ & $\begin{array}{l}0.0025 \\
0.0634\end{array}$ \\
\hline $\begin{array}{l}\text { Food } \\
\text { OLS } \\
\text { R.E. }\end{array}$ & $\begin{array}{l}2.139 * * * \\
1.742 * * *\end{array}$ & $\begin{array}{l}- \\
0.760 * * * \\
- \\
0.707 * * *\end{array}$ & $\begin{array}{l}0.029 \\
0.053 * *\end{array}$ & $\begin{array}{l}0.309 * * * \\
0.188 * * *\end{array}$ & $\begin{array}{l}0.182 * * * \\
0.144 * * *\end{array}$ & $\begin{array}{l}0 \\
0\end{array}$ & $\begin{array}{l} \\
0.234 * * * \\
- \\
0.157 * * * \\
\end{array}$ & 0 & 0 & $\begin{array}{l}0.0000 \\
0.0000\end{array}$ & $\begin{array}{l}0.0000 \\
0.0000\end{array}$ \\
\hline $\begin{array}{l}\text { Furn. } \\
\text { OLS } \\
\text { R.E. }\end{array}$ & $\begin{array}{l}0.336 * * * \\
0.407 * * *\end{array}$ & $\begin{array}{l}0.659 * * * \\
0.597 * * *\end{array}$ & $\begin{array}{l}0.02 \\
0.023\end{array}$ & $\begin{array}{l}0 \\
0\end{array}$ & $\begin{array}{l}0 \\
0\end{array}$ & $\begin{array}{l}0 \\
0\end{array}$ & $\begin{array}{l}0 \\
0\end{array}$ & $\begin{array}{l}0 \\
0\end{array}$ & $\begin{array}{l}0 \\
0\end{array}$ & $\begin{array}{l}\mathrm{CD} \\
\mathrm{CD}\end{array}$ & $\begin{array}{l}0.7126 \\
0.5302\end{array}$ \\
\hline $\begin{array}{l}\text { Leather } \\
\text { OLS } \\
\text { R.E. }\end{array}$ & $\begin{array}{l}0.878 * * * \\
0.816 * * *\end{array}$ & $\begin{array}{l}0.288 * \\
0.285 * * *\end{array}$ & $\begin{array}{l}0.086 * * * \\
0.096\end{array}$ & $\begin{array}{l}0 \\
0\end{array}$ & $\begin{array}{l}0 \\
0\end{array}$ & $\begin{array}{l}0 \\
0\end{array}$ & $\begin{array}{l}0 \\
0\end{array}$ & $\begin{array}{l}0 \\
0\end{array}$ & $\begin{array}{l}0 \\
0\end{array}$ & $\begin{array}{l}\mathrm{CD} \\
\mathrm{CD}\end{array}$ & $\begin{array}{l}0.0207 \\
0.1025\end{array}$ \\
\hline $\begin{array}{l}\text { NonMet. } \\
\text { OLS } \\
\text { R.E. }\end{array}$ & $\begin{array}{l}0.305 * * * \\
0.415 * * *\end{array}$ & $\begin{array}{l}-0.356 \\
-0.508^{*}\end{array}$ & $\begin{array}{l}0.096 * * * \\
0.099 * *\end{array}$ & $\begin{array}{l}0 \\
0\end{array}$ & $\begin{array}{l}0.086 * * \\
0.090 * * *\end{array}$ & $\begin{array}{l}0 \\
0\end{array}$ & $\begin{array}{l}0 \\
0\end{array}$ & $\begin{array}{l}0 \\
0\end{array}$ & $\begin{array}{l}0 \\
0\end{array}$ & $\begin{array}{l}0.0288 \\
0.0005\end{array}$ & $\begin{array}{c}0.0833 \\
0.0022\end{array}$ \\
\hline $\begin{array}{l}\text { Textiles } \\
\text { OLS } \\
\text { R.E. }\end{array}$ & $\begin{array}{l}0.359 * * \\
0.429 * * *\end{array}$ & $\begin{array}{l}0.374 * * * \\
0.311 * * *\end{array}$ & $\begin{array}{l}0.225 * \\
0.232 * *\end{array}$ & $\begin{array}{l}0 \\
0\end{array}$ & $\begin{array}{l}0 \\
0\end{array}$ & $\begin{array}{l}0 \\
0\end{array}$ & $\begin{array}{l}0 \\
0\end{array}$ & $\begin{array}{l}0 \\
0\end{array}$ & $\begin{array}{l}0 \\
0\end{array}$ & $\begin{array}{l}\mathrm{CD} \\
\mathrm{CD}\end{array}$ & $\begin{array}{l}0.5901 \\
0.7078\end{array}$ \\
\hline $\begin{array}{l}\text { Metal } \\
\text { OLS } \\
\text { R.E. }\end{array}$ & $\begin{array}{l}0.732 * * \\
0.846 * *\end{array}$ & $\begin{array}{l}0.036 \\
-0.266\end{array}$ & $\begin{array}{l}0.216 \\
0.283\end{array}$ & $\begin{array}{l}0 \\
0\end{array}$ & $\begin{array}{l}0.102 * * * \\
0.118 * * *\end{array}$ & $\begin{array}{l}0.026 \\
0.01\end{array}$ & $\begin{array}{l}-0.033 \\
-0.041\end{array}$ & $\mid \begin{array}{l}0 \\
0\end{array}$ & $\begin{array}{l}-0.043 * \\
-0.033\end{array}$ & $\begin{array}{l}0.0294 \\
0.1375\end{array}$ & $\begin{array}{c}0.0246 \\
0.1354\end{array}$ \\
\hline
\end{tabular}

Notes:

(1) Significance is given by robust standard errors. * significant at $10 \%$; ** significant at 5\%; *** significant at $1 \%$.

(2) CD indicates that a Cobb-Douglas specification was estimated since it was preferred to the Translog specification.

(3) 0 indicates that the coefficient of that input in that industry was not significant and hence is restricted to be equal to 0 . 
Econometric Methodologies for Investment Climate Assessments on Productivity

Table C.6.1: Two Step Unrestricted by Industry Estimation for Young and Old Firms

Dependent Variable: Unrestricted by Industry Solow Residuals in Levels (logs)

\begin{tabular}{|c|c|c|c|}
\hline & & Young Plants & Old Plants \\
\hline \multirow[t]{8}{*}{$\begin{array}{l}\text { Red Tape, Corruption and } \\
\text { Crime }\end{array}$} & \multirow[t]{2}{*}{$\begin{array}{l}\text { Number of days spent in Inspection and } \\
\text { Regulation related work }\end{array}$} & -0.077 & $-0.081^{*}$ \\
\hline & & {$[0.067]$} & {$[0.046]$} \\
\hline & \multirow[t]{2}{*}{$\begin{array}{l}\text { Fraction of sales undeclared to the tax authority } \\
\text { for tax purposes }\end{array}$} & -0.261 & -0.481 \\
\hline & & {$[0.582]$} & {$[0.294]$} \\
\hline & \multirow[t]{2}{*}{$\begin{array}{l}\text { Payments to deal with bureaucracy "faster", } \\
\text { percent of sales }\end{array}$} & $0.037^{*}$ & $0.036^{* \star}$ \\
\hline & & {$[0.019]$} & {$[0.014]$} \\
\hline & \multirow[t]{2}{*}{ Number of criminal attempts suffered } & -0.009 & $-0.029 * \star$ \\
\hline & & {$[0.021]$} & {$[0.012]$} \\
\hline \multirow[t]{8}{*}{ Infrastructure } & \multirow[t]{2}{*}{ Average duration of power outages $(\log )$} & -0.085 & $-0.097^{*}$ \\
\hline & & {$[0.098]$} & {$[0.053]$} \\
\hline & \multirow[t]{2}{*}{ Days to clear customs for imports (log) } & $-0.168^{\star \star}$ & -0.067 \\
\hline & & {$[0.074]$} & [0.043] \\
\hline & \multirow[t]{2}{*}{ Shipment Losses (fraction of Sales) } & -0.948 & $-2.321^{\star \star}$ \\
\hline & & [1.037] & {$[1.181]$} \\
\hline & \multirow[t]{2}{*}{ Dummy for Internet Access } & 0.1 & $0.156^{\star \star \star}$ \\
\hline & & {$[0.073]$} & {$[0.044]$} \\
\hline \multirow{10}{*}{$\begin{array}{l}\text { Quality, Innovation and } \\
\text { Labor Skills }\end{array}$} & \multirow[t]{2}{*}{ Fraction of computer-controlled machinery } & -0.191 & $0.218^{\star \star}$ \\
\hline & & {$[0.193]$} & {$[0.086]$} \\
\hline & \multirow[t]{2}{*}{ Fraction of total staff engaged in R\&D } & -0.369 & $0.773^{\star \star}$ \\
\hline & & {$[0.567]$} & {$[0.320]$} \\
\hline & \multirow[t]{2}{*}{ Dummy for ISO quality certification } & 0.12 & 0.16 \\
\hline & & {$[0.196]$} & {$[0.110]$} \\
\hline & \multirow[t]{2}{*}{$\begin{array}{l}\text { Fraction of total staff with secondary education } \\
\text { or higher }\end{array}$} & 0.09 & 0.06 \\
\hline & & {$[0.115]$} & {$[0.075]$} \\
\hline & \multirow[t]{2}{*}{$\begin{array}{l}\text { Dummy for Training provided beyond "on the } \\
\text { job" training }\end{array}$} & $0.144^{\star \star}$ & $0.093^{\star \star}$ \\
\hline & & {$[0.067]$} & {$[0.042]$} \\
\hline \multirow{4}{*}{$\begin{array}{ll}\text { Finance and Corporate } \\
\text { Governance }\end{array}$} & \multirow{2}{*}{ Dummy for Incorporated Company } & $0.199^{\star \star}$ & $0.132^{\star \star \star}$ \\
\hline & & {$[0.087]$} & {$[0.044]$} \\
\hline & \multirow{2}{*}{\begin{tabular}{|l}
$\begin{array}{l}\text { Dummy for external audit of Financial } \\
\text { statements }\end{array}$ \\
\end{tabular}} & $0.212^{\star \star \star}$ & $0.152^{\star \star \star}$ \\
\hline & & [0.073] & {$[0.049]$} \\
\hline \multirow[t]{10}{*}{ Others Control Variables } & \multirow[t]{2}{*}{ Age of the firm $(\log )$} & 0.03 & 0.022 \\
\hline & & {$[0.076]$} & {$[0.030]$} \\
\hline & \multirow[t]{2}{*}{ Share of Imported inputs (fraction) } & -0.016 & $0.133^{\star \star}$ \\
\hline & & {$[0.103]$} & {$[0.055]$} \\
\hline & Observations & 1461 & 1461 \\
\hline & R-squared & 0.27 & 0.27 \\
\hline & Test of joint significance & Prob $>F=0.0004$ & Prob $>F=0.0004$ \\
\hline & of IC Variables & & \\
\hline & Test of joint significance & Prob $>F=0.0000$ & Prob $>F=0.0000$ \\
\hline & of ICVs and Plant level controls & & \\
\hline
\end{tabular}

Notes:

(1) All the coefficients in the table are obtained from a single regression.

(2) Significance is given by robust standard errors. * significant at 10\%; ** significant at 5\%; *** significant at $1 \%$.

(3) The regressions include a constant, industry dummies, country dummies and year dummies.

(4) Young plants are defined as those less than 5 years old, and old plants as those more than 5 years old. 
Table C.6.2: Two Step Unrestricted by Industry Estimation for Small and Large Firms

Dependent Variable: Unrestricted by Industry Solow Residuals in Levels (logs)

\begin{tabular}{|c|c|c|c|}
\hline & & Small Plants & Large Plants \\
\hline \multirow{8}{*}{$\begin{array}{l}\text { Red Tape, Corruption and } \\
\text { Crime }\end{array}$} & \multirow[t]{2}{*}{$\begin{array}{l}\text { Number of days spent in Inspection and } \\
\text { Regulation related work }\end{array}$} & -0.075 & -0.089 \\
\hline & & {$[0.048]$} & {$[0.060]$} \\
\hline & \multirow[t]{2}{*}{$\begin{array}{l}\text { Fraction of sales undeclared to the tax authority } \\
\text { for tax purposes }\end{array}$} & $-0.491^{*}$ & -0.322 \\
\hline & & {$[0.283]$} & {$[0.499]$} \\
\hline & \multirow[t]{2}{*}{$\begin{array}{l}\text { Payments to deal with bureaucracy "faster", } \\
\text { percent of sales }\end{array}$} & $0.033^{\star \star}$ & $0.032^{*}$ \\
\hline & & {$[0.015]$} & {$[0.017]$} \\
\hline & \multirow[t]{2}{*}{ Number of criminal attempts suffered } & -0.016 & $-0.039^{\star \star \star}$ \\
\hline & & {$[0.016]$} & {$[0.014]$} \\
\hline \multirow[t]{8}{*}{ Infrastructure } & \multirow[t]{2}{*}{ Average duration of power outages $(\log )$} & -0.077 & -0.085 \\
\hline & & {$[0.059]$} & {$[0.080]$} \\
\hline & \multirow[t]{2}{*}{ Days to clear customs for imports $(\log )$} & $-0.088^{*}$ & -0.06 \\
\hline & & {$[0.045]$} & {$[0.057]$} \\
\hline & \multirow[t]{2}{*}{ Shipment Losses (fraction of Sales) } & $-1.733^{\star}$ & -1.412 \\
\hline & & [1.008] & [1.255] \\
\hline & \multirow[t]{2}{*}{ Dummy for Internet Access } & $0.125^{\star \star}$ & 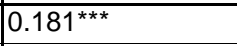 \\
\hline & & {$[0.049]$} & {$[0.060]$} \\
\hline \multirow{10}{*}{$\begin{array}{l}\text { Quality, Innovation and } \\
\text { Labor Skills }\end{array}$} & \multirow{2}{*}{ Fraction of computer-controlled machinery } & 0.06 & $0.174^{*}$ \\
\hline & & {$[0.138]$} & {$[0.105]$} \\
\hline & \multirow[t]{2}{*}{ Fraction of total staff engaged in R\&D } & $0.530^{*}$ & -0.183 \\
\hline & & [0.301] & [1.395] \\
\hline & \multirow[t]{2}{*}{ Dummy for ISO quality certification } & 0.082 & $0.206^{*}$ \\
\hline & & {$[0.153]$} & [0.111] \\
\hline & \multirow{2}{*}{$\begin{array}{l}\text { Fraction of total staff with secondary education } \\
\text { or higher }\end{array}$} & 0.072 & 0.016 \\
\hline & & {$[0.078]$} & {$[0.103]$} \\
\hline & \multirow[t]{2}{*}{$\begin{array}{l}\text { Dummy for Training provided beyond "on the } \\
\text { job" training }\end{array}$} & $0.138^{\star \star \star}$ & 0.069 \\
\hline & & {$[0.047]$} & {$[0.053]$} \\
\hline \multirow{4}{*}{$\begin{array}{l}\text { Finance and Corporate } \\
\text { Governance }\end{array}$} & \multirow{2}{*}{ Dummy for Incorporated Company } & $0.148^{\star \star \star}$ & $0.126^{\star \star}$ \\
\hline & & {$[0.053]$} & {$[0.060]$} \\
\hline & \multirow[t]{2}{*}{$\begin{array}{l}\begin{array}{l}\text { Dummy for external audit of Financial } \\
\text { statements }\end{array} \\
\end{array}$} & $0.166^{\star \star \star}$ & $0.185^{\star \star \star}$ \\
\hline & & {$[0.059]$} & {$[0.057]$} \\
\hline \multirow[t]{10}{*}{ Others Control Variables } & \multirow[t]{2}{*}{ Age of the firm $(\log )$} & $0.052^{\star}$ & $0.055^{\star \star}$ \\
\hline & & {$[0.029]$} & {$[0.024]$} \\
\hline & \multirow[t]{2}{*}{ Share of Imported inputs (fraction) } & $0.137^{\star \star}$ & 0.072 \\
\hline & & {$[0.063]$} & {$[0.077]$} \\
\hline & Observations & 1461 & 1461 \\
\hline & R-squared & 0.26 & 0.26 \\
\hline & Test of joint significance & Prob $>F=0.0000$ & Prob $>F=0.0000$ \\
\hline & of IC Variables & & \\
\hline & Test of joint significance & Prob $>F=0.0000$ & Prob $>F=0.0000$ \\
\hline & of ICVs and Plant level controls & & \\
\hline
\end{tabular}

Notes:

(1) All the coefficients in the table are obtained from a single regression.

(2) Significance is given by robust standard errors. * significant at 10\%; ** significant at 5\%; *** significant at $1 \%$.

(3) The unrestricted by industry Solow Residual is obtained using cost shares for inputs (labor, materials and capital) obtained as averages for each of the industries using plants in the 3 countries for years 2001 and 2002 .

(4) The regressions include a constant, industry dummies, country dummies and year dummies.

(5) Small plants are defined as those having up to 25 employees and large plants as those having 26 or more employees. 
Table C.7.1: Covariance Terms by Country of the Olley -Pakes Decomposition from Different Productivity Measures

\begin{tabular}{|l|l|l|l|}
\hline Productivity Measures & Guatemala & Honduras & Nicaragua \\
\hline $\begin{array}{l}\text { Solow Residual of Restricted } \\
\text { Model }\end{array}$ & 0.3488 & -0.0731 & -0.0534 \\
\hline $\begin{array}{l}\text { Cobb Douglas Estimated Productivity of } \\
\text { Restricted Model }\end{array}$ & 0.234 & -0.0341 & -0.0439 \\
\hline $\begin{array}{l}\text { Translog Estimated Productivity of } \\
\text { Restricted Model }\end{array}$ & 0.2786 & -0.0836 & $\mathbf{0 . 0 3 9 9}$ \\
\hline $\begin{array}{l}\text { Solow Residual of Unrestricted } \\
\text { Model }\end{array}$ & 0.1335 & -0.1354 & -0.0098 \\
\hline $\begin{array}{l}\text { Cobb Douglas Estimated Productivity of } \\
\text { Unrestricted Model }\end{array}$ & 0.4010 & $\mathbf{0 . 0 8 5 3}$ & $\mathbf{0 . 7 5 1 8}$ \\
\hline $\begin{array}{l}\text { Translog Estimated Productivity of } \\
\text { Unrestricted Model }\end{array}$ & 1.1751 & $\mathbf{0 . 1 6 3 1}$ & -0.1717 \\
\hline
\end{tabular}

Table C.7.2: Covariance Terms by Country and Plant Size of the Olley-Pakes Decomposition from Different Productivity Measures

\begin{tabular}{|l|l|l|l|l|}
\hline Productivity Measures & Firm Size & Guatemala & Honduras & Nicaragua \\
\hline \multirow{2}{*}{$\begin{array}{l}\text { Solow Residual of Restricted } \\
\text { Model }\end{array}$} & Small & 0.4927 & -0.1579 & 0.0507 \\
\cline { 2 - 5 } & Large & 0.2832 & -0.0322 & -0.1072 \\
\hline \multirow{2}{*}{$\begin{array}{l}\text { Cobb Douglas Estimated Productivity } \\
\text { of Restricted Model }\end{array}$} & Small & 0.2825 & -0.0853 & 0.0028 \\
\cline { 2 - 5 } & Large & 0.1076 & -0.0032 & -0.0722 \\
\hline \multirow{2}{*}{$\begin{array}{l}\text { Translog Estimated Productivity of } \\
\text { Restricted Model }\end{array}$} & Small & 0.082 & -0.0655 & 0.0237 \\
\cline { 2 - 5 } & Large & 0.1396 & -0.0051 & -0.0261 \\
\hline \multirow{2}{*}{$\begin{array}{l}\text { Solow Residual of Unrestricted } \\
\text { Model }\end{array}$} & Small & 0.5617 & -0.1370 & 0.0410 \\
\cline { 2 - 5 } & Large & 0.1743 & -0.1208 & -0.0234 \\
\hline $\begin{array}{l}\text { Cobb Douglas Estimated Productivity } \\
\text { of Unrestricted Model }\end{array}$ & Small & 0.2921 & -0.1039 & 0.1259 \\
\cline { 2 - 5 } & Large & 0.2127 & $\mathbf{0 . 0 4 4 3}$ & $\mathbf{0 . 5 3 2 2}$ \\
\hline $\begin{array}{l}\text { Translog Estimated Productivity of } \\
\text { Unrestricted Model }\end{array}$ & Small & 0.0412 & -0.2192 & $\mathbf{0 . 0 2 2 3}$ \\
\cline { 2 - 5 } & Large & 0.6798 & $\mathbf{0 . 1 8 6 8}$ & $\mathbf{0 . 0 3 8 7}$ \\
\hline
\end{tabular}




\section{Econometric Methodologies for Investment Climate Assessments on Productivity}

\section{Table D: Elasticities or Semi-elasticities and Percentage R-square Productivity Contribution of Each Explanatory Variable, after Controlling for the Other IC and Plant Control Variables}

\begin{tabular}{|c|c|c|c|c|c|c|}
\hline & \multicolumn{3}{|c|}{ Restricted OLS Estimation } & \multicolumn{3}{|c|}{ Unrestricted OLS Estimation } \\
\hline & \multirow[b]{2}{*}{ Solow Res. } & \multicolumn{2}{|l|}{1 step } & \multirow[b]{2}{*}{ Solow Res. } & \multicolumn{2}{|l|}{1 step } \\
\hline & & Cobb Douglas & Translog & & Cobb Douglas & Translog \\
\hline \multicolumn{7}{|l|}{ Red Tape, Corruption and Crime } \\
\hline \multirow{2}{*}{$\begin{array}{l}\text { Number of days spent in Inspection and } \\
\text { Regulation related work }\end{array}$} & $-0.097^{\star \star}$ & $-0.099 * \star$ & -0.058 & $-0.101^{\star \star}$ & $-0.107^{\star \star}$ & $-0.068^{\star}$ \\
\hline & $0.76 \%$ & $0.79 \%$ & $0.26 \%$ & $0.81 \%$ & $0.97 \%$ & $0.45 \%$ \\
\hline \multirow{2}{*}{$\begin{array}{l}\text { Fraction of sales undeclared to the tax authority } \\
\text { for tax purposes }\end{array}$} & $-0.601^{\star *}$ & $-0.612^{\star \star}$ & $-0.416^{*}$ & $-0.676^{\star \star}$ & $-0.767^{\star \star \star}$ & $-0.593^{\star \star}$ \\
\hline & $0.77 \%$ & $0.81 \%$ & $0.65 \%$ & $0.97 \%$ & $1.31 \%$ & $0.92 \%$ \\
\hline \multirow{2}{*}{$\begin{array}{l}\text { Payments to deal with bureaucracy "faster", } \\
\text { percent of sales }\end{array}$} & $0.031^{* *}$ & $0.033^{\star \star \star}$ & 0.015 & $0.031^{\star \star}$ & $0.030^{\star \star}$ & 0.013 \\
\hline & $0.76 \%$ & $0.84 \%$ & $0.18 \%$ & $0.74 \%$ & $0.75 \%$ & $0.16 \%$ \\
\hline \multirow[t]{2}{*}{ Number of criminal attempts suffered } & $-0.029 \star \star$ & $-0.031^{\star \star \star}$ & -0.018 & $-0.032^{\star \star \star}$ & $-0.029 * \star$ & -0.018 \\
\hline & $0.73 \%$ & $0.85 \%$ & $0.21 \%$ & $0.88 \%$ & $0.75 \%$ & $0.36 \%$ \\
\hline \multicolumn{7}{|l|}{ Infrastructure } \\
\hline \multirow[t]{2}{*}{ Average duration of power outages $(\log )$} & $-0.095^{\star}$ & $-0.085^{\star}$ & -0.072 & $-0.088^{*}$ & -0.075 & -0.024 \\
\hline & $0.35 \%$ & $0.29 \%$ & $0.18 \%$ & $0.30 \%$ & $0.23 \%$ & $0.03 \%$ \\
\hline \multirow[t]{2}{*}{ Days to clear customs for imports $(\log )$} & $-0.097^{\star \star}$ & $-0.106^{\star \star}$ & $-0.125^{\star \star \star}$ & $-0.105^{\star \star \star}$ & $-0.105^{\star \star}$ & $-0.119^{\star \star \star}$ \\
\hline & $0.93 \%$ & $1.11 \%$ & $1.91 \%$ & $1.08 \%$ & $1.14 \%$ & $1.67 \%$ \\
\hline \multirow[t]{2}{*}{ Shipment Losses (fraction of Sales) } & $-1.860^{\star *}$ & $-2.119^{\star \star}$ & -1.229 & $-1.948^{\star \star}$ & $-2.530^{\star \star \star}$ & $-2.063^{\star \star}$ \\
\hline & $0.20 \%$ & $0.26 \%$ & $0.18 \%$ & $0.22 \%$ & $0.38 \%$ & $0.30 \%$ \\
\hline \multirow[t]{2}{*}{ Dummy for Internet Access } & $0.147^{\star \star \star}$ & $0.144^{\star \star \star}$ & $0.119^{\star \star \star}$ & $0.139^{\star \star \star \star}$ & $0.128^{\star \star \star}$ & $0.111^{\star \star \star}$ \\
\hline & $1.51 \%$ & $1.47 \%$ & $4.99 \%$ & $1.35 \%$ & $1.28 \%$ & $1.06 \%$ \\
\hline \multicolumn{7}{|l|}{ Quality, Innovation and Labor Skills } \\
\hline \multirow{2}{*}{ Fraction of computer-controlled machinery } & 0.119 & 0.13 & $0.132^{*}$ & 0.117 & 0.131 & 0.084 \\
\hline & $0.14 \%$ & $0.17 \%$ & $0.47 \%$ & $0.13 \%$ & $0.18 \%$ & $0.09 \%$ \\
\hline \multirow[t]{2}{*}{ Fraction of total staff engaged in $R \& D$} & $0.594^{\star \star}$ & $0.667^{\star \star}$ & $0.581^{\star \star}$ & $0.589^{\star \star}$ & $0.607^{\star \star}$ & $0.580^{\star \star}$ \\
\hline & $0.40 \%$ & $0.51 \%$ & $0.02 \%$ & $0.39 \%$ & $0.44 \%$ & $0.47 \%$ \\
\hline \multirow[t]{2}{*}{ Dummy for ISO quality certification } & 0.154 & 0.167 & 0.024 & 0.142 & $0.176^{*}$ & 0.105 \\
\hline & $0.27 \%$ & $0.32 \%$ & $0.06 \%$ & $0.23 \%$ & $0.37 \%$ & $0.16 \%$ \\
\hline \multirow{2}{*}{$\begin{array}{l}\text { Fraction of total staff with secondary education } \\
\text { or higher }\end{array}$} & 0.036 & 0.048 & 0.03 & 0.033 & 0.054 & 0.056 \\
\hline & $0.03 \%$ & $0.06 \%$ & 0.02 & $0.03 \%$ & $0.08 \%$ & $0.10 \%$ \\
\hline \multirow{2}{*}{$\begin{array}{l}\text { Dummy for Training provided beyond "on the } \\
\text { job" training }\end{array}$} & $0.117^{* \star \star}$ & $0.105^{\star \star \star}$ & $0.089^{\star \star \star}$ & $0.116^{\star \star \star}$ & $0.110^{\star \star \star}$ & $0.098^{\star \star \star}$ \\
\hline & $0.95 \%$ & $0.78 \%$ & $2.15 \%$ & $0.94 \%$ & $0.90 \%$ & $0.81 \%$ \\
\hline \multicolumn{7}{|l|}{ Finance and Corporate Governance } \\
\hline \multirow[t]{2}{*}{ Dummy for Incorporated Company } & $0.150^{\star \star \star}$ & $0.140^{\star \star \star}$ & $0.115^{\star \star \star}$ & $0.146^{\star \star \star}$ & $0.132^{\star \star \star}$ & $0.117^{\star \star \star}$ \\
\hline & $1.48 \%$ & $1.31 \%$ & $5.19 \%$ & $1.41 \%$ & $1.21 \%$ & $1.12 \%$ \\
\hline Dummy for external audit of Financial & $0.168^{* \star \star}$ & $0.159^{\star \star \star}$ & $0.121^{\star \star \star}$ & $0.170^{\star \star \star}$ & $0.150^{\star \star \star}$ & $0.116^{\star \star \star}$ \\
\hline & $1.80 \%$ & $1.64 \%$ & $4.06 \%$ & $1.84 \%$ & $1.52 \%$ & $1.06 \%$ \\
\hline Others Control Variables & & & & & & \\
\hline Age of the firm $(\log )$ & $0.050^{* *}$ & $0.049^{* *}$ & $0.046^{* \star}$ & $0.051^{\star \star *}$ & $0.043^{* *}$ & $0.032^{*}$ \\
\hline & $0.48 \%$ & $0.46 \%$ & 0.93 & $0.50 \%$ & $0.37 \%$ & $0.23 \%$ \\
\hline Share of Imported inputs (fraction) & $0.113^{\star \star}$ & $0.101^{* *}$ & $0.096^{\star \star}$ & $0.110^{\star \star}$ & 0.074 & $0.101^{\star \star}$ \\
\hline & $0.55 \%$ & $0.45 \%$ & $2.32 \%$ & $0.53 \%$ & $0.25 \%$ & $0.55 \%$ \\
\hline R-Squared & 0.2 & 0.2 & 0.36 & 0.26 & 0.51 & 0.94 \\
\hline
\end{tabular}

Notes:

(1) Robust standard errors shown in parentheses under coefficient estimates

(2) Significance is given by robust standard errors. * significant at 10\%; ** significant at 5\%; *** significant at $1 \%$.

(3) The regressions include a constant, industry dummies, country dummies and year dummies. 


\section{Econometric Methodologies for Investment Climate Assessments on Productivity}

Table E.1: Guatemala

$\%$ Average (log) Productivity Gains and Losses in Guatemala due to Investment Climate (IC)

\begin{tabular}{|c|c|c|c|c|c|c|}
\hline & \multicolumn{3}{|c|}{ Restricted OLS Estimation } & \multicolumn{3}{|c|}{ Unrestricted OLS Estimation } \\
\hline & \multirow[b]{2}{*}{ Solow Res. } & \multicolumn{2}{|l|}{1 Step } & \multirow[b]{2}{*}{ Solow Res. } & \multicolumn{2}{|c|}{1 Step } \\
\hline & & Cobb Douglas & Translog & & Cobb Douglas & Translog \\
\hline \multicolumn{7}{|l|}{ Red Tape, Corruption and Crime } \\
\hline $\begin{array}{l}\text { Number of days spent in Inspection and } \\
\text { Regulation related work }\end{array}$ & $-5.89^{* *}$ & $-5.61 * *$ & -1.97 & $-6.09 * *$ & $-6.23 * *$ & $-2.74^{*}$ \\
\hline $\begin{array}{l}\text { Fraction of sales undeclared to the tax } \\
\text { authority for tax purposes }\end{array}$ & $-3.31 * *$ & $-3.16^{* *}$ & $-1.73^{*}$ & $-3.71 * *$ & $-4.04 * * *$ & $-2.18 * *$ \\
\hline $\begin{array}{l}\text { Payments to deal with bureaucracy } \\
\text { "faster", percent of sales }\end{array}$ & $2.83 * *$ & $2.79 * * *$ & 0.78 & $2.8^{* *}$ & $2.62 * *$ & 0.78 \\
\hline Number of criminal attempts suffered & $-2.13 * *$ & $-2.14 * * *$ & -0.65 & $-2.32 * * *$ & $-2.0 * *$ & -0.9 \\
\hline Cumulative Contribution & -8.5 & -8.12 & -3.57 & -9.32 & -9.65 & -5.04 \\
\hline Cumulative Absolute Contribution & 14.16 & 13.7 & 5.15 & 14.92 & 14.89 & 6.6 \\
\hline \multicolumn{7}{|l|}{ Infrastructure } \\
\hline Average duration of power outages $(\log )$ & $-1.65^{*}$ & $-1.40 *$ & -0.67 & $-1.53^{*}$ & -1.25 & -0.27 \\
\hline Days to clear customs for imports $(\log )$ & $-5.39 * *$ & $-5.5 * *$ & $-4.42 * * *$ & $-5.82 * * *$ & $-5.58 * *$ & $-4.4 * * *$ \\
\hline Shipment Losses (fraction of Sales) & $-0.74 * *$ & $-0.79 * *$ & -0.4 & $-0.77 * *$ & $-0.96 * * *$ & $-0.55^{* *}$ \\
\hline Dummy for Internet Access & $2.61 * * *$ & $2.39 * * *$ & $2.74 * * *$ & $2.46^{* * *}$ & $2.16^{* * *}$ & $1.32 * * *$ \\
\hline Cumulative Contribution & -5.17 & -5.3 & -2.75 & -5.66 & -5.63 & -3.9 \\
\hline Cumulative Absolute Contribution & 10.39 & 10.08 & 8.23 & 10.58 & 9.95 & 6.54 \\
\hline \multicolumn{7}{|l|}{ Quality, Innovation and Labor Skills } \\
\hline Fraction of computer-controlled machinery & 0.22 & 0.23 & $0.23 *$ & 0.22 & 0.24 & 0.11 \\
\hline Fraction of total staff engaged in $R \& D$ & $0.7 * *$ & $0.74 * *$ & $0.08 * *$ & $0.69 * *$ & $0.69^{* *}$ & $0.46^{* *}$ \\
\hline Dummy for ISO quality certification & 0.13 & 0.13 & 0.03 & 0.12 & $0.14 *$ & 0.06 \\
\hline $\begin{array}{l}\text { Fraction of total staff with secondary } \\
\text { education or higher }\end{array}$ & 0.33 & 0.42 & 0.14 & 0.31 & 0.49 & 0.35 \\
\hline $\begin{array}{l}\text { Dummy for Training provided beyond "on } \\
\text { the job" training }\end{array}$ & $1.57^{* * *}$ & $1.33 * * *$ & $1.35 * * *$ & $1.56^{* * *}$ & $1.42 * * *$ & $0.88 * * *$ \\
\hline Cumulative Contribution & 2.95 & 2.85 & 1.83 & 2.9 & 2.98 & 1.86 \\
\hline \multicolumn{7}{|l|}{ Finance and Corporate Governance } \\
\hline Dummy for Incorporated Company & $2.1 * * *$ & $1.84 * * *$ & $2.27 * * *$ & $2.04 * * *$ & $1.76^{* * *}$ & $1.1 * * *$ \\
\hline $\begin{array}{l}\text { Dummy for external audit of Financial } \\
\text { statements }\end{array}$ & $1.52 * * *$ & $1.35^{* * *}$ & $1.31 * * *$ & $1.54 * * *$ & $1.3 * * *$ & $0.7 * * *$ \\
\hline Cumulative Contribution & 3.62 & 3.19 & 3.58 & 3.58 & 3.06 & 1.8 \\
\hline \multicolumn{7}{|l|}{ Others Control Variables } \\
\hline Age of the firm $(\log )$ & $3.35 * *$ & $3.07 * *$ & $2.66^{* *}$ & $3.42 * * *$ & $2.73 * *$ & $1.42 *$ \\
\hline Share of Imported inputs (fraction) & $0.94 * *$ & $0.8^{* *}$ & $1.1^{* *}$ & $0.92 * *$ & 0.59 & $0.57 * *$ \\
\hline Cumulative Contribution & 4.29 & 3.87 & 3.76 & 4.34 & 3.32 & 1.99 \\
\hline Grand Total Contribution & -3.35 & -3.51 & 2.85 & -4.16 & -5.83 & -3.32 \\
\hline Grand Total Absolute Contribution & 35.41 & 33.69 & 22.53 & 36.32 & 34.2 & 18.79 \\
\hline
\end{tabular}

Note: (1) The asterisks correspond to the significance level of the variables in the corresponding OLS regression: * significant at $10 \% ; * *$ significant at $5 \%$; *** significant at $1 \%$. 


\section{Econometric Methodologies for Investment Climate Assessments on Productivity}

Table E.2: Honduras

$\%$ Average (log) Productivity Gains and Losses in Honduras due to Investment Climate (IC)

\begin{tabular}{|c|c|c|c|c|c|c|}
\hline & \multicolumn{3}{|c|}{ Restricted OLS Estimation } & \multicolumn{3}{|c|}{ Unrestricted OLS Estimation } \\
\hline & \multirow[b]{2}{*}{ Solow Res. } & \multicolumn{2}{|l|}{1 Step } & \multirow[b]{2}{*}{ Solow Res. } & \multicolumn{2}{|c|}{1 Step } \\
\hline & & Cobb Douglas & Translog & & Cobb Douglas & Translog \\
\hline \multicolumn{7}{|l|}{ Red Tape, Corruption and Crime } \\
\hline $\begin{array}{l}\text { Number of days spent in Inspection and } \\
\text { Regulation related work }\end{array}$ & $-6.34 * *$ & $-6.03 * *$ & -2.15 & $-6.66^{* *}$ & $-6.74 * *$ & $-2.9^{*}$ \\
\hline $\begin{array}{l}\text { Fraction of sales undeclared to the tax } \\
\text { authority for tax purposes }\end{array}$ & $-4.48^{* *}$ & $-4.28 * *$ & $-2.37 *$ & $-5.13 * *$ & $-5.51 * * *$ & $-2.91 * *$ \\
\hline $\begin{array}{l}\text { Payments to deal with bureaucracy } \\
\text { "faster", percent of sales }\end{array}$ & $1.84^{* *}$ & $1.81 * * *$ & 0.51 & $1.85 * *$ & $1.72 * *$ & 0.5 \\
\hline Number of criminal attempts suffered & $-0.82 * *$ & $-0.83 * * *$ & -0.25 & $-0.91 * * *$ & $-0.78 * *$ & -0.34 \\
\hline Cumulative Contribution & -9.8 & -9.33 & -4.26 & 10.85 & -11.31 & 4.97 \\
\hline Cumulative Absolute Contribution & 13.48 & 12.95 & 5.28 & 14.55 & 14.75 & 6.65 \\
\hline \multicolumn{7}{|l|}{ Infrastructure } \\
\hline Average duration of power outages (log) & $-2.89 *$ & $-2.45^{*}$ & -1.19 & $-2.73 *$ & -2.21 & -0.47 \\
\hline Days to clear customs for imports $(\log )$ & $-3.73 * *$ & $-3.8^{* *}$ & $-3.09^{* *}$ & $-4.1 * * *$ & $-3.89 * *$ & $-2.99^{* * *}$ \\
\hline Shipment Losses (fraction of Sales) & $-0.74 * *$ & $-0.79 * *$ & -0.41 & $-0.79 * *$ & $-0.97 * * *$ & $-0.54 * *$ \\
\hline Dummy for Internet Access & $1.74 * * *$ & $1.6^{* * *}$ & $1.85^{* * *}$ & $1.7 * * *$ & $1.45^{* * *}$ & $0.87 * * *$ \\
\hline Cumulative Contribution & -5.62 & -5.44 & -2.84 & -5.92 & -5.62 & -3.13 \\
\hline Cumulative Absolute Contribution & 9.1 & 8.64 & 6.54 & 9.32 & 8.52 & 4.87 \\
\hline \multicolumn{7}{|l|}{ Quality, Innovation and Labor Skills } \\
\hline Fraction of computer-controlled machinery & 0.2 & 0.21 & $0.22^{*}$ & 0.2 & 0.22 & 0.1 \\
\hline Fraction of total staff engaged in R\&D & $0.4^{* *}$ & $0.42 * *$ & $0.4^{* *}$ & $0.4^{* *}$ & $0.39 * *$ & $0.25 * *$ \\
\hline Dummy for ISO quality certification & 0.18 & 0.18 & 0.05 & 0.18 & $0.2^{*}$ & 0.08 \\
\hline $\begin{array}{l}\text { Fraction of total staff with secondary } \\
\text { education or higher }\end{array}$ & 0.29 & 0.37 & 0.12 & 0.27 & 0.42 & 0.3 \\
\hline $\begin{array}{l}\text { Dummy for Training provided beyond "on } \\
\text { the job" training }\end{array}$ & $1.34^{* * *}$ & $1.13^{* * *}$ & $1.16^{* * *}$ & $1.35^{* * *}$ & $1.22 * * *$ & $0.73^{* * *}$ \\
\hline Cumulative Contribution & 2.41 & 2.31 & 1.95 & 2.4 & 2.45 & 1.46 \\
\hline \multicolumn{7}{|l|}{ Finance and Corporate Governance } \\
\hline Dummy for Incorporated Company & $0.91 * * *$ & $0.79 * * *$ & $1 * * *$ & $0.9^{* * *}$ & $0.77^{* * *}$ & $0.47 * * *$ \\
\hline $\begin{array}{l}\text { Dummy for external audit of Financial } \\
\text { statements }\end{array}$ & $1.71 * * *$ & $1.52 * * *$ & $1.49 * * *$ & $1.76^{* * *}$ & $1.47^{* * *}$ & $0.77 * * *$ \\
\hline Cumulative Contribution & 2.62 & 2.31 & 2.49 & 2.66 & 2.24 & 1.24 \\
\hline \multicolumn{7}{|l|}{ Others Control Variables } \\
\hline Age of the firm $(\log )$ & $2.95 * *$ & $2.69^{* *}$ & $2.37 * *$ & $3.06^{* * *}$ & $2.42 * *$ & $1.23^{*}$ \\
\hline Share of Imported inputs (fraction) & $0.78^{* *}$ & $0.66^{* *}$ & $0.92 * *$ & $0.77 * *$ & $0.49^{* *}$ & $0.46^{* *}$ \\
\hline Cumulative Contribution & 3.73 & 3.35 & 3.29 & 3.83 & 2.91 & 1.69 \\
\hline Grand Total Contribution & -6.66 & -6.8 & 0.63 & -7.88 & -9.33 & -4.39 \\
\hline Grand Total Absolute Contribution & 31.34 & 29.56 & 19.55 & 32.76 & 30.87 & 15.91 \\
\hline
\end{tabular}

Note: (1) The asterisks correspond to the significance level of the variables in the corresponding OLS regression: * significant at $10 \%$; ** significant at $5 \% ; * * *$ significant at $1 \%$. 
Table E.3: Nicaragua

\% Average (log) Productivity Gains and Losses in Nicaragua due to Investment Climate (IC)

\begin{tabular}{|c|c|c|c|c|c|c|}
\hline & \multicolumn{3}{|c|}{ Restricted OLS Estimation } & \multicolumn{3}{|c|}{ Unrestricted OLS Estimation } \\
\hline & \multirow[b]{2}{*}{ Solow Res. } & \multicolumn{2}{|l|}{1 Step } & \multirow[b]{2}{*}{ Solow Res. } & \multicolumn{2}{|c|}{1 Step } \\
\hline & & Cobb Douglas & Translog & & Cobb Douglas & Translog \\
\hline \multicolumn{7}{|l|}{ Red Tape, Corruption and Crime } \\
\hline $\begin{array}{l}\text { Number of days spent in Inspection and } \\
\text { Regulation related work }\end{array}$ & $-7.9 * *$ & $-7.5 * *$ & -2.64 & $-8.31 * *$ & $-8.41 * *$ & $-3.82 *$ \\
\hline $\begin{array}{l}\text { Fraction of sales undeclared to the tax } \\
\text { authority for tax purposes }\end{array}$ & $-5.41^{* *}$ & $-5.16^{* *}$ & $-2.82^{*}$ & $-6.18^{* *}$ & $-6.65 * * *$ & $-3.71^{* *}$ \\
\hline $\begin{array}{l}\text { Payments to deal with bureaucracy "faster", } \\
\text { percent of sales }\end{array}$ & $1.49^{* *}$ & $1.47^{* * *}$ & 0.41 & $1.5^{* *}$ & $1.39 * *$ & 0.43 \\
\hline Number of criminal attempts suffered & $-0.72 * *$ & $-0.72 * * *$ & -0.22 & $-0.8 * * *$ & $-0.68 * *$ & -0.31 \\
\hline Cumulative Contribution & -12.54 & -11.91 & -5.27 & -13.79 & -14.25 & -7.41 \\
\hline Cumulative Absolute Contribution & 15.52 & 14.85 & 6.09 & 16.79 & 17.13 & 8.27 \\
\hline \multicolumn{7}{|l|}{ Infrastructure } \\
\hline Average duration of power outages $(\log )$ & $-2.83 *$ & $-2.39 *$ & -1.14 & $-2.66^{*}$ & -2.15 & -0.49 \\
\hline Days to clear customs for imports $(\log )$ & $-3.91 * *$ & $-3.98 * *$ & $-3.2 * * *$ & $-4.29 * * *$ & $-4.07 * *$ & $-3.31 * * *$ \\
\hline Shipment Losses (fraction of Sales) & $-0.86^{* *}$ & $-0.92 * *$ & -0.47 & $-0.92 * *$ & $-1.13 * * *$ & $-0.67^{* *}$ \\
\hline Dummy for Internet Access & $1.54 * * *$ & $1.41^{* * *}$ & $1.61^{* * *}$ & $1.46^{* * *}$ & $1.29^{* * *}$ & $0.81^{* * *}$ \\
\hline Cumulative Contribution & -6.06 & -6.86 & -3.2 & -6.41 & -6.06 & -3.66 \\
\hline Cumulative Absolute Contribution & 9.14 & 9.68 & 6.42 & 9.33 & 8.64 & 5.28 \\
\hline \multicolumn{7}{|l|}{ Quality, Innovation and Labor Skills } \\
\hline Fraction of computer-controlled machinery & 0.12 & 0.13 & $0.13^{*}$ & 0.13 & 0.13 & 0.06 \\
\hline Fraction of total staff engaged in R\&D & $0.53 * *$ & $0.56^{* *}$ & $0.06^{* *}$ & $0.53 * *$ & $0.52 * *$ & $0.36^{* *}$ \\
\hline Dummy for ISO quality certification & 0.19 & 0.19 & 0.05 & 0.17 & $0.2^{*}$ & 0.09 \\
\hline $\begin{array}{l}\text { Fraction of total staff with secondary } \\
\text { education or higher }\end{array}$ & 0.36 & 0.46 & 0.15 & 0.34 & 0.53 & 0.4 \\
\hline $\begin{array}{l}\text { Dummy for Training provided beyond "on } \\
\text { the job" training }\end{array}$ & $1.16^{* * *}$ & $0.98^{* * *}$ & $0.99^{* * *}$ & $1.17^{* * *}$ & $1.06^{* * *}$ & $0.67^{* * *}$ \\
\hline Cumulative Contribution & 2.36 & 2.32 & 1.38 & 2.34 & 2.44 & 1.58 \\
\hline \multicolumn{7}{|l|}{ Finance and Corporate Governance } \\
\hline Dummy for Incorporated Company & $1.35^{* * *}$ & $1.18^{* * *}$ & $1.47^{* * *}$ & $1.34 * * *$ & $1.15^{* * *}$ & $0.74 * * *$ \\
\hline $\begin{array}{l}\text { Dummy for external audit of Financial } \\
\text { statements }\end{array}$ & $1.3 * * *$ & $1.16^{* * *}$ & $1.12^{* * *}$ & $1.34^{* * *}$ & $1.12^{* * *}$ & $0.62^{* * *}$ \\
\hline Cumulative Contribution & 2.65 & 2.34 & 2.59 & 2.68 & 2.27 & 1.36 \\
\hline \multicolumn{7}{|l|}{\begin{tabular}{|l|} 
Others Control Variables \\
\end{tabular}} \\
\hline Age of the firm $(\log )$ & $3.51^{* *}$ & $3.2 * *$ & $2.78^{* *}$ & $3.63^{* * *}$ & $2.88 * *$ & $1.54 *$ \\
\hline Share of Imported inputs (fraction) & $1.06 * *$ & $0.89^{* *}$ & $1.24 * *$ & $1.05 * *$ & 0.67 & $0.67 * *$ \\
\hline Cumulative Contribution & 4.57 & 4.09 & 4.02 & 4.68 & 3.55 & 2.21 \\
\hline Grand Total Contribution & -9.02 & -10.02 & -0.48 & -10.5 & -12.05 & -5.92 \\
\hline Grand Total Absolute Contribution & 34.24 & 33.28 & 20.5 & 35.8 & 34.03 & 18.7 \\
\hline
\end{tabular}

Note:

(1) The asterisks correspond to the significance level of the variables in the corresponding OLS regression: * significant at $10 \% ; * *$ significant at $5 \% ; * * *$ significant at $1 \%$. 
Figure 7

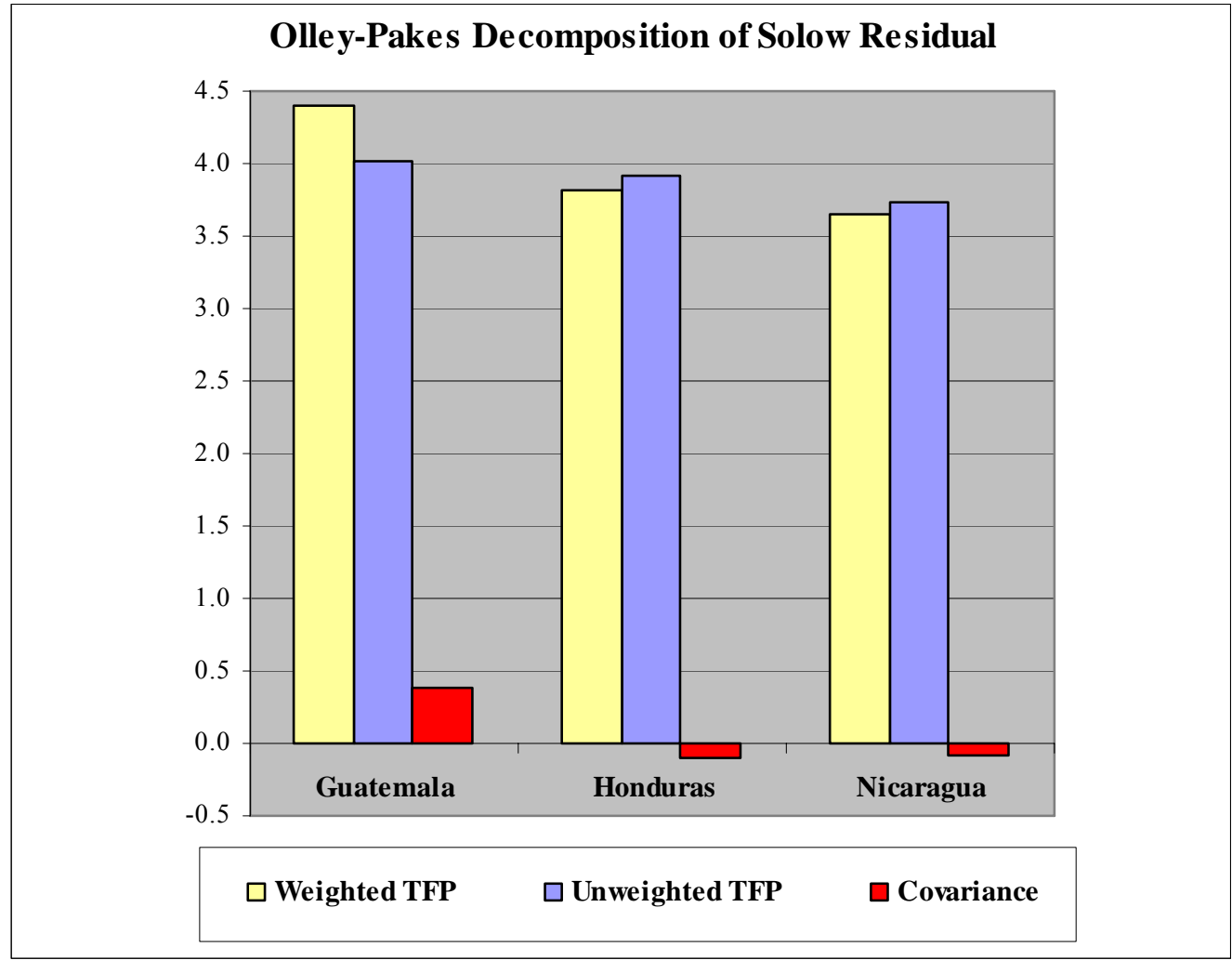

Figure 8

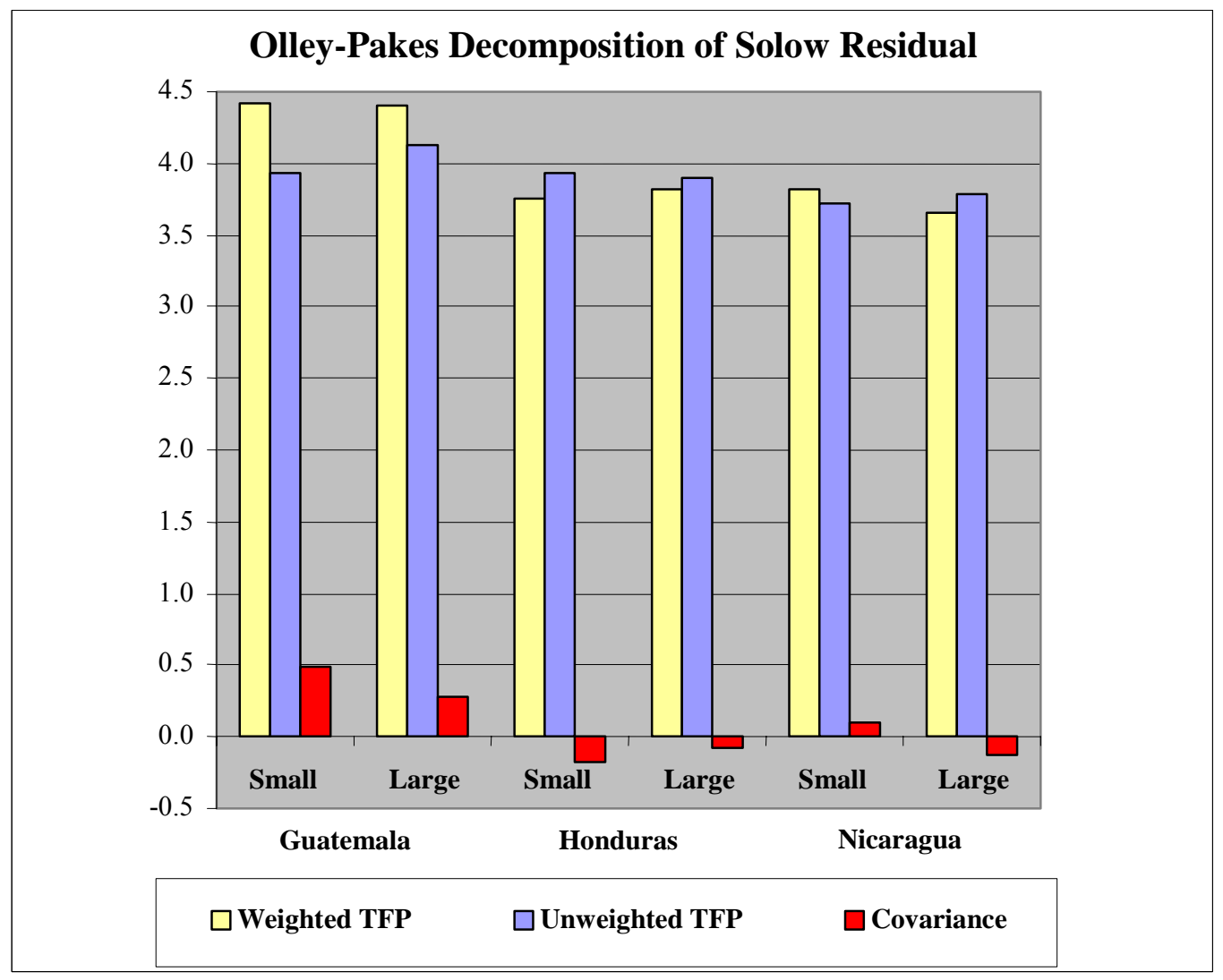


Figure 9
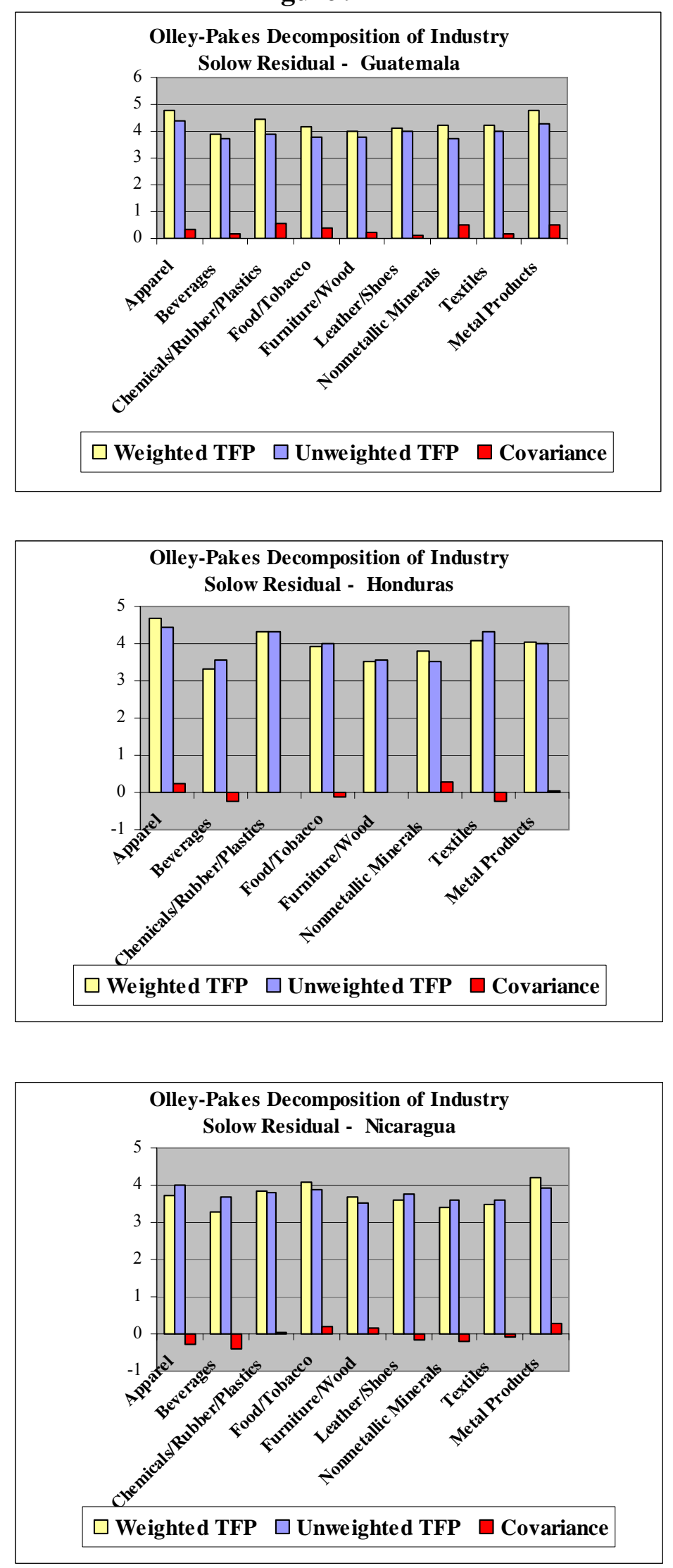


\section{References}

Ackerberg D. A. and K. Caves (2003). "Structural Identification of Production Functions". Working Paper, University of California, Los Angeles.

Alexander, W. Robert J., Bell, John D., and Knowles, Stephen (2004). 'Quantifying Compliance Costs of Small Businesses in New Zealand". Discussion paper, University of Otahgo. http://www.business.otago.ac.nz/econ/research/discussionpapers/DPO406.pdf.

Arellano M. (2003). Panel Data Econometrics. Advanced Texts in Econometrics, Oxford University Press.

Barro R. J. and X. Sala-i-Martin (2004). Economic Growth. The MIT Press, second edition, Cambridge, Massachusetts.

Bartelsman E. J. and M. Doms (2000). "Understanding Productivity: Lessons from Longitudinal Microdata”. Journal of Economic Literature, Vol. 38, № 3, 569-594.

Basu S. and J. Fernand (2001). "Why is Productivity Procyclical? Why do we Care?". In Ch. R. Hulten, E.R. Dean and M. J. Harper (eds.) New Developments in Productivity Analysis, The University of Chicago Press, 225-301.

Blundell R. and S. Bond (2000). "GMM Estimation with Persistent Panel Data: An Application to Production Functions”. Econometric Reviews, 19 (3), 321-340.

Blundell R. and J. L. Powell (2003). 'Endogeneity in Nonparametric and Semiparametric Regression Models" In Advances in Economics and Econonometrics: Theory and Applications, Eighth World Congress, Vol. II, M. Dewatripont, L.P. Hansen and S.J. Turnovsky, eds. Cambridge: Cambridge University Press, 313-357.

Bosworth, Barry and Susan Collins (2003). "The Empirics of Growth: An Update". The Brookings Institution. Washington, D.C. Processed.

Cole, H. L., L. E. Ohanian, A. Riascos and J. A. Schmitz Jr. (2004). "Latin America in the Rearview Mirror". National Bureau of Economic Research WP \#11008, December.

De Soto, Hernando (2002). "The Mystery of Capital: Why Capitalism Triumphs in the West and Fails Everywhere Else". New York: Basic Books Press.

Diewert W. Erwin and Alice O. Nakamura (2002) "The Measurement of Aggregate Total Factor Productivity Growth”. J. J. Heckman and E. E. Leamer (eds.). Handbook of Econometrics, Vol. 6, forthcoming.

Djankov, Simeon, La Porta, Rafael, Lopez-de-Silanis, Florencio, and Shleifer, Andrei (2002). "The Regulation of Entry". Quarterly Journal of Economics 117, February 2002. 137. 
Dollar, David, Anqing Shi, Shuilin Wang and L. Colin. Xu (2004). "Improving City Competitiveness through the Investment Climate: Ranking 23 Chinese Cities". Washington, D.C., World Bank.

Dollar, David, Mary Hallward-Driemeier and Taye Mengistae (2004). "Investment Climate and International Integration". Washington, D.C., World Bank.

Dollar, David, Mary Hallward-Driemeier and Taye Mengistae (2003). "Investment Climate and Firm Performance in Developing Economies”. Washington, D.C., World Bank.

Escribano Alvaro and J. Luis Guasch (2004). "Econometric Methodology for Investment Climate Assessments (ICA) on Productivity using Firm Level Data: The Case of Guatemala, Honduras and Nicaragua". Mimeo World Bank, June.

Escribano Alvaro and Jorge Pena (2004). "Productivity in Levels or in Differences:

Evaluation of the Impact of ICT from Firm Level Data on the Spanish Manufacturing Sector". Working Paper, Universidad Carlos III de Madrid.

Foster L., J. Haltiwanger and C.J. Krizan (1998). "Aggregate Productivity Growth: Lessons from Microeconomic Evidence”. NBER Working Paper W6803.

Griliches Z. (1996). "The Discovery of the Residual: A Historical Note". Journal of Economic Literature, 34, 1324-1330.

Griliches Z. and J. Mairesse (1997). "Production Functions: The Search for Identification". In S. Strom (ed.) Essays in Honor of Ragnar Frisch, Econometric Society Monograph Series, Cambridge University Press, Cambidge.

Guasch, J. Luis. (2004). "An Assesment of Logistic Costs and of their Impact on Competitiveness", World Bank, Washington, DC.

Hall R. E. (1988). "The Relationship between Price and Marginal Cost in U.S. Industry”. Journal of Political Economy, 96, 5, 921-947.

Hall R. E. (1990). "Invariance Properties of Solow's Productivity Residual”. In Peter Diamond (ed.). Growth, Productivity, Employment. Cambridge: MIT Press, 1-53.

Hall R. E. and Ch. I. Jones (1997). "Levels of Economic Activity Across Countries". American Economic Review 87, 173-177.

Hall R. E. and Ch. I. Jones (1999). "Why do Some Countries Produce so Much More Output per Worker than Others?”. The Quarterly Journal of Economics. Feb. 83-116.

Haltiwanger, John (2002). "Understanding Economic Growth". The Need for Micro Evidence”. New Zealand Economic Papers 36 (1), 33-58.

He, Kathy S., Morck, Randall, and Yeung, Bernard (2003). "Corporate Stability and Economic Growth”. William Davidson Working Paper No. 553. 
Hulten Ch. R. (2001). “Total Factor Productivity: A Short Biography”. In Ch. R. Hulten, E.R. Dean and M. J. Harper (eds.) New Developments in Productivity Analysis, The University of Chicago Press, 1-47.

Im, K.S., M.H. Pesaran and Y. Shin (2003). "Testing for Unit Roots in Heterogenous Panels". Journal of Economics, 115, 53-74.

Johnson, Simon, McMillan, John, and Woodruff, Christopher (2002). "Property Rights and Finance". American Economic Review 92, 1335-56.

Jorgenson D.W. (2001). "Information Technology and the U.S. Economy". The American Economic Review, Vol. 91, 1, 1-32.

Jorgenson D.W., F. Gollop and B. Fraumeni (1987). Productivity and U.S. Economic Growth. Cambridge: Harvard University Press.

Jorgenson D.W. and Z. Griliches (1967). "The Explanation of Productivity Change". Review of Economic Studies, 34, 249-280.

Kasper, Wolfgang, (2002), "Losing Sight of the Lodestar of Economic Freedom: A Report Card on New Zeland's Economic Reform”, NZ Business Roundtable.

Kerr, Roger (2002). ”The Quagmire of Regulation” NZ Business Roundtable. http://www.nzbr.org.nz/documents/speeches/speeches200/the quagmire of regulation.pdf.

Klapper, Leora, Laeven, Luc, and Rajan, Raghuram (2004). "Business Environment and Firm Entry". NBER paper 10380. http://papers.nber.org/papers/W10380.

Levinsohn J. and A. Petrin (2003). "Estimating Production Functions Using Inputs to Control for Unobservables”. Review of Economic Studies, 70, 317-341.

Loayza, N.V., A. M. Oviedo and Luis Serven (2004). "Regulation and Macroeconomic Performance", World Bank, Washington DC.

Marschak J. and W. H. Andrews (1944). "Random Simultaneous Equations and the Theory of Production”. Econometrica, 12 (3,4), 143-205.

McMillan, John, (1998), “ Managing Economic Change: Lessons from New Zeland”, The World Economy 21, 827-43.

Mc Millan, John (2004), “A Flexible Economy? Entrepeneurship and Productivity in New Zeland”, Working Paper, Graduate Scholl of Business, Stanford University, Stanford, CA.

Olley G. S.and A. Pakes (1996). "The Dynamics of Productivity in the Telecommunications Equipment Industry”. Econometrica, Vol. 64, 6, 1263-1297.

Organization for Economic Cooperation and Development (2001). Businesses' Views on Red Tape, Paris, OECD. http://www1.oecd.org/publications/e-book/4201101E.PDF. 
Prescot, Edward C. (1998) "Needed: A Theory of Total Factor Productivity". International Economic Review, 39, 525-552.

Rodrik, Dani, and Arvind Subramanian (2004). "From 'Hindu Growth to Productivity Surge: The Mystery of the Indian Growth Transition". Harvard University, Cambridge, Mass. Processed.

Solow R. M. (1957). "Technical Change and the Aggregate Production Function". The Review of Economics and Statistics, 39 (3), 312-320.

Stiroh K.J. (2002). "Information Technology and the U.S. Productivity Revival: Whta Do the Industry Data Say?” The American Economic Review, Vol. 92, 5, 1559-1575.

Tornqvist L. (1936). “The Bank of Finland's Consumption Price Index”. Bank of Finland Monthly Bulletin, 10, 1-8.

Wooldridge J. M. (2002). Econometric Analysis of Cross Section and Panel Data. The MIT Press. Cambridge, Massachusetts.

World Bank 2003. "Doing Business in 2004" Understanding Regulation. Washington, D.C. World Bank.

2004. "Doing Business in 2005: Removing Obstacles to Growth". Washington, D.C. World Bank.

2004. "2003 Annual Review of Development Effectiveness: The Effectiveness of Bank Support for Policy Reform. Report 28290”. Washington, D.C.: World Bank Operations Evaluation Department.

2005. "World Development Report 2005: A Better Investment Climate for Everyone". World Bank and Oxford University Press. Washington, D.C.

Wilkinson, Bryce (2001). “Constraining Government Regulation”. NZ Business Roundtable. http://www.nzbr.org.nz/documents/publications/publications2001/constraining govt.pdf. 